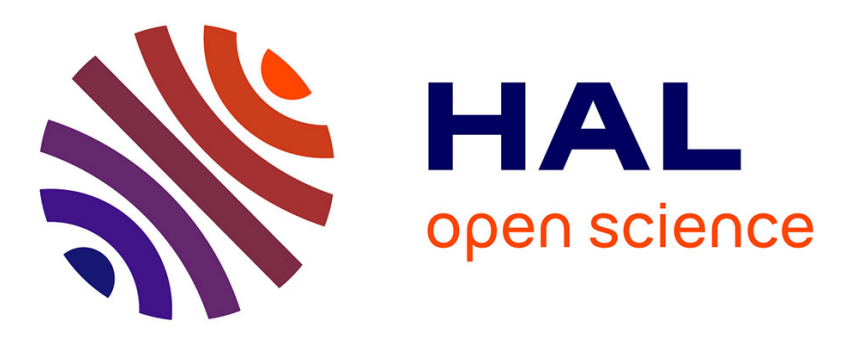

\title{
A suture related accretionary wedge in the Gondwana assembly: Insights from serpentinites in the Hoggar shield, Algeria
}

Sonia Ouadahi, Abderrahmane Bendaoud, Jean-Louis Bodinier, Jean-Marie Dautria, Alain Vauchez, El-Hocine Fettous, Olivier Alard

\section{To cite this version:}

Sonia Ouadahi, Abderrahmane Bendaoud, Jean-Louis Bodinier, Jean-Marie Dautria, Alain Vauchez, et al.. A suture related accretionary wedge in the Gondwana assembly: Insights from serpentinites in the Hoggar shield, Algeria. Precambrian Research, 2022, 369, pp.106505. 10.1016/j.precamres.2021.106505 . hal-03504162

\section{HAL Id: hal-03504162 \\ https://hal.umontpellier.fr/hal-03504162}

Submitted on 28 Dec 2021

HAL is a multi-disciplinary open access archive for the deposit and dissemination of scientific research documents, whether they are published or not. The documents may come from teaching and research institutions in France or abroad, or from public or private research centers.
L'archive ouverte pluridisciplinaire HAL, est destinée au dépôt et à la diffusion de documents scientifiques de niveau recherche, publiés ou non, émanant des établissements d'enseignement et de recherche français ou étrangers, des laboratoires publics ou privés. 


\title{
A suture related accretionary wedge in the Gondwana assembly: insights from serpentinites in the Hoggar shield, Algeria
}

\author{
Published in Precambrian Research \\ DOI: $10.1016 / j$.precamres.2021.106505
}

Sonia Ouadahi ${ }^{\mathrm{a}, \mathrm{b}^{*}}$, Abderrahmane Bendaoud ${ }^{\mathrm{b}}$, Jean-Louis Bodinier ${ }^{\mathrm{a}, \mathrm{c}}$, Jean-Marie Dautria ${ }^{\mathrm{a}}$, Alain Vauchez ${ }^{\text {a }}$, El-Hocine Fettous ${ }^{\mathrm{b}}$, Olivier Alard ${ }^{\mathrm{a}, \mathrm{d}}$

${ }^{a}$ Géosciences Montpellier, Université de Montpellier, CNRS, 34095 Montpellier, France.

${ }^{\mathbf{b}}$ Faculty of Earth sciences, University of Sciences and Technology Houari Boumediene, 16123 Algiers, Algeria.

${ }^{\mathbf{c}}$ Geology and Sustainable Mining, Mohammed VI Polytechnic University, 43150, Benguerir, Morocco.

${ }^{\text {d }}$ Department of Earth and Planetary Science, Macquarie University, Sydney NSW 2109, Australia.

* Corresponding author.

E-mail: ssoniaouadahi@gmail.com

\section{Highlights}

- First field, petro-geochemical and chronological data of In-Tedeini serpentinites.

- Data and models point to a mantle wedge origin and variable magmatic processes.

- They outline an important suture zone in the central-western Hoggar and Gondwana.

- A new Neoproterozoic geodynamic model of the central-western Hoggar is proposed. 


\begin{abstract}
The assembly of West Gondwana supercontinent involved several complex processes that led to the formation of the Hoggar shield during the Panafrican-Brasiliano event. We present the first petro-geochemical, geochronological and field data of serpentinite lenses exposed along the InTedeini domain, within deformed talc-schist and magmatic-sedimentary formations. The serpentinites preserved the main characteristics of their parent peridotites ( $\mathrm{Al} / \mathrm{Si}: 0.004-0.03$; Mg/Si: 1.14 - 1.62; Al2O3: 0.15 - 1.37 wt\%; Mg\#: 85.3 - 94; Ti: 9.34 - 120 ppm; Nb: 0.007 $0.46 \mathrm{ppm}$ ), attesting to a highly depleted mantle wedge protolith involved in a subduction zone. This is in agreement with the high Cr\# (0.55 - 0.6), low to moderate Mg\# (0.36 - 0.65) and low $\mathrm{TiO}_{2}$ contents $(<0.1 \mathrm{wt} \%)$ of their constitutive Cr-spinels. Geochemical modelling suggest that both the North and South In-Tedeini serpentinite units have experienced intense and similar fluidinduced dynamic melting episodes. The evolution of these two units has diverged, with the Southern In-Tedeini unit being refertilized by a small volume of island-arc basaltic melts generated in the mantle wedge. Serpentinization of these rocks probably occurred under static conditions at high temperature corresponding essentially to amphibolite-facies conditions. Field relations suggest that the exhumation of the massive serpentinites occurred along major sinistral shear zones steeply dipping eastward, assisted by talc-schists that highly localized transpressive deformation. First U-Pb zircon ages obtained from a metasomatic chloritite in North In-Tedeini serpentinites; they may have recorded the age $(770 \pm 5 \mathrm{Ma})$ of the subduction related Panafrican island arcs and the emplacement $(631 \pm 10 \mathrm{Ma})$ of In-Tedeini serpentinites within the crust; or they may rather correspond to the serpentinization events endured by the rocks. All together, the reported results support the presence of a major suture zone, oriented NNW-SSE. This suture is outlined by mantle serpentinite lenses exhumed in a collisional accretionary wedge, which connects the western and the central Hoggar, following a Panafrican east-dipping subduction. This tectonic system would have contributed to the closure of the Goiás-Pharusian ocean.
\end{abstract}

Keywords: Serpentinite; mantle wedge, Neoproterozoic, Panafrican belt; West Gondwana orogen; Suture. 


\section{Graphical abstract}

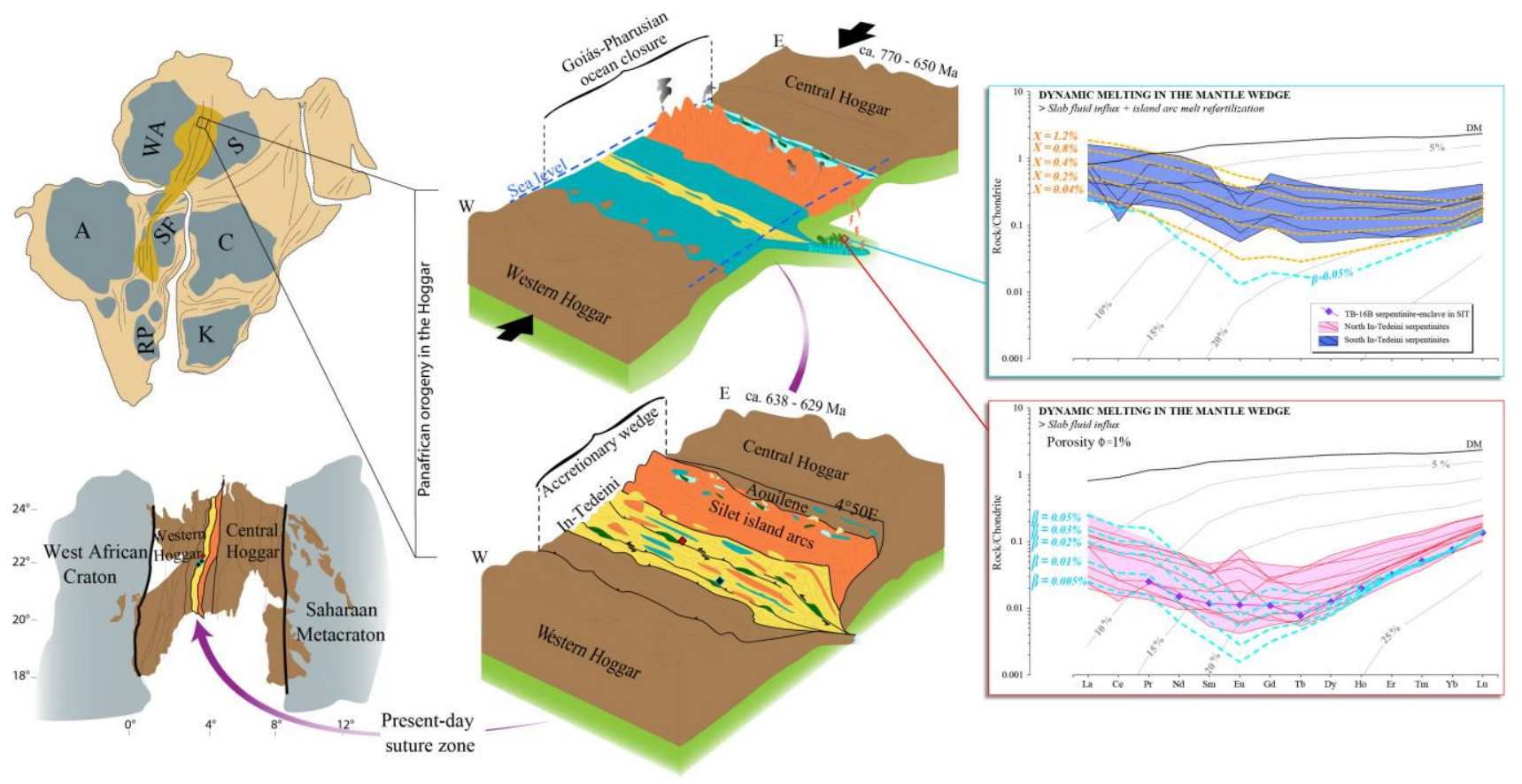




\section{Introduction}

Neoproterozoic geodynamic evolution, particularly during the Panafrican orogeny (870 $540 \mathrm{Ma}$ ), is characterized by a major rearrangement of continental masses, with consumption and closure of oceans that resulted in successive continental collisions and accretion of island arcs leading to the Gondwana supercontinent assembly (e.g., Caby, 1989,2003; Kröner and Cordani, 2003; Cordani et al., 2013). In this context, one of largest branches of the Panafrican-Brasiliano orogenic system (e.g., Caby et al., 1991; Ganade de Araújo et al., 2014b; and references therein) formed by the progressive convergence and oblique collision of the Amazonian and West African cratons against the São Francisco and the Saharan paleocontinents (Fig. 1a) during the closure of the major Goiás-Pharusian ocean that initially separated the cratonic blocks and surroundings (Caby, 1989, 2003).

The Hoggar represents the northern and largest part of the Tuareg Shield within the Panafrican belt developed between the West African and Saharan paleocontinents (Fig. 1b). It results from a complex evolution and there is a consensus to consider that it formed through the amalgamation of blocks of different origins and ages including oceanic and continental arcs (Black et al., 1994; Caby, 2003; Liégeois et al., 2003; Liégeois, 2019; Deramchi et al., 2020). In the last decades, different connections between the Hoggar shield in Africa and the various Brasiliano orogenic belts of South America have been proposed (Fig. 1a; Caby, 1989, 2003; Castaing et al., 1994, Toteu et al. 2001, Brito Neves et al. 2002, Oliveira et al. 2006, Arthaud et al. 2008, Dada 2008, Santos et al. 2008b; De Wit et al., 2008; Cordani et al., 2013; Ganade de Araujo et al., 2014a, b, 2016; Caxito et al., 2020a). Various suture zones have been suggested within the Hoggar (Fig. 1b; Caby, 1989, 2003; Brahimi et al., 2018; Liégeois, 2019; Deramchi et al., 2020; and references therein), but only few studies were performed on them. For a long time, the $4^{\circ} 50^{\prime} \mathrm{E}$ lithospheric shear zone (Fig. 1b) was considered to be the main suture of this orogen which would extends to South America in the form of the Transbrasiliano-Kandi mega shear zone (Caby, 1989; Arthaud et al., 2008; Cordani et al., 2013b; Ganade de Araújo et al., 2014b). However, recent studies (Brahimi et al., 2018; Liégeois, 2019; Deramchi et al., 2020) inferred the presence of a major suture zone located west of Silet domain (Fig. 1b), which connects the western and the central Hoggar (Caby, 2003; Liégeois et al., 2003). The interpretation of this new suture zone relies mostly on geophysical data and lacks complementary petrological and tectonic evidence to 
ascertain its occurrence at the suggested location. The western boundary of this proposed suture zone, which corresponds to the eastern In-Tedeini domain, is underlined by several elongate serpentinite bodies. So far, neither petrological nor tectonic characteristics and evolution of these serpentinite bodies have been thoroughly investigated. However, few studies have been devoted to the ultramafic rocks present in the eastern Silet domain. They have been interpreted as (1) remnants of an ophiolitic sequence (Abed, 1983), (2) related to an island arc or a marginal basin (Dupont et al., 1987), and (3) layered cumulatic intrusions (Boukhalfa, 1987) contemporaneous to the expansion of intracontinental rifting during the Panafrican orogeny. The latter interpretation is supported by the occurrence of alkaline and tholeïtic metabasaltic series (Dupont et al., 1987; Bouchachi, 1993; Boukhalfa, 2002). Despite the general characterization of Silet ultramafics, a possible mantle origin of serpentinites in the western Hoggar is still not constrained and several questions concerning their geodynamic evolution in the Neoproterozoic time remain open.

Many studies have been performed on serpentinites around the world during the last decades (e.g., O’Hanley, 1996; Guillot et al., 2009, 2015; Evans et al., 2013; Guillot and Hattori, 2013; Deschamps et al., 2013; Alt et al., 2013; Peters et al., 2017; Scambelluri et al., 2019; Brovarone et al., 2020). In most cases, serpentinized peridotites are part of residual upper mantle and provide excellent opportunities to characterize their protoliths and their geological history when 'fresh' peridotites are lacking. They may provide important constraints on the origin, tectonic evolution and petrological processes that affected the parent rocks (e.g., Deschamps et al., 2013; Evans et al., 2013; Guillot et al., 2015). Compilation of data from Neoproterozoic ophiolites and related serpentinites reveals a large majority of subduction-related units and also important interaction processes with fluids and melts during their geodynamic evolution, marked by the demise of the Rodinia and the assembly of Gondwana supercontinents (eg., Dilek and Furnes, 2011; Stern et al., 2012; Kusky et al., 2013; Furnes et al., 2014, 2015; El Dien et al., 2016; Hodel et al., 2019, 2020).

In this paper, we present field, petro-geochemical, mineral chemistry and geochronological data as well as magmatic modelling of several serpentinite bodies, which are distributed along the eastern part of In-Tedeini domain within magmatic and sedimentary formations (Fig. 1c). Our aim is to determine their origin and constrain the geodynamic context of their emplacement. These InTedeini serpentinites offer an opportunity to substantiate or disprove that this domain results from 
the closure of a paleo ocean and, thus, identify a geological suture zone as the contact between the western and the central domains, likely associated to the Gondwana assembly.

\section{Geological setting}

The northern part of the Tuareg shield in the southern Algeria, the Hoggar swell, is a large structure $(500 \mathrm{~km}$ x $600 \mathrm{~km})$ uplifted in the Eocene (Lesquer et al., 1988; Dautria and Lesquer, 1989; Rougier et al., 2013), exposing the Precambrian rocks and basement. The geology of the Hoggar is characterized by the juxtaposition of 25 terranes composed of juvenile Neoproterozoic rocks and variably reworked Archean and Paleoproterozoic basement blocks assembled during the Panafrican orogeny (Black et al., 1994; Caby, 2003; Liégeois, 2019). The various terranes of the Hoggar shield were amalgamated during the convergence of the West African craton and the Saharan paleocontinent. The orogenic belt developed in between connects the Benino-Nigerian shield, the Cameroon and Dahomey belt, and the Borborema province in Brazil (Fig. 1a; e.g., Caby, 1989; Trompette, 1994; Cordani et al., 2013; Ganade de Araujo et al., 2014a,b, 2016;

Caxito et al., 2020a). The Hoggar orogenic structure is characterized by roughly $\sim \mathrm{N}-\mathrm{S}$-trending trans-lithospheric shear zones (e.g., Black et al., 1994; Brahimi et al., 2018; Liégeois, 2019).

The Eastern Pharusian branch of the Panafrican system extends west of the LATEA block (central Hoggar) from the 450'E and Eifel to the Adrar shear zones and involves, from east to west, the so-called Silet, In-Tedeini and Tin Zaouatene domains (Fig. 1b, c). They were interpreted as a set of Neoproterozoic island arcs resulting from intra-oceanic subduction during an early stage of the Panafrican orogeny (Chikhaoui et al., 1980; Caby et al., 2003; Bechiri-Benmerzoug, 2012). This subduction system would have consumed part of the Goiás-Pharusian ocean located between the Archean-Paleoproterozoic basement that dominate the LATEA and the western domains of the Hoggar shield. A rifting period prior to oceanization was suggested ( 1Ga-900 Ma; Dupont et al., 1987; Bouchachi, 1993; Caby, 2003; Caxito et al., 2020a) and several episodes of intra-oceanic arc accretions in Silet domain are substantiated by volcanic arc series, tonalitetrondhjemite-granodiorite (TTG) units, and calc-alkaline granites, ranging in age from 870 to 638 Ma (Caby et al., 1982; Bechiri-Benmerzoug, 2012, 2017). According to Liégeois et al. (2003), the Silet domain was thrust onto the LATEA block (Fig. 1b), which is considered to represent a passive margin during that period. The In-Tedeini and Tin Zaouatene domains were considered as 
belonging to the juvenile Panafrican belt, but recently a Paleoproterozoic continental basement was recognized in Tin Zaouatene and western part of In-Tedeini domains (Meriem et al., 2004; Bosch et al., 2016; Brahimi et al., 2018; Deramchi et al., 2020). The Silet - In-Tedeini boundary (west-Silet shear zone) appears as a major anomaly (Fig. 1b) within the crust and lithospheric mantle in gravimetric, magnetic and magnetotelluring maps and sections (Brahimi et al., 2018, Deramchi et al., 2020), a fact that supports its interpretation as the suture between the central and western Hoggar domains.

The present study is focused on serpentinites exposed west of the proposed suture zone (i.e., west-Silet shear zone) in an area of about $8500 \mathrm{~km}^{2}$ within the In-Tedeini domain (Fig. 1b, c). To the south, the serpentinite bodies are bounded by the Imezzarene granitoid (583 Ma; Lapique et al., 1986), which is affected by the NE-oriented Amded shear zone, a Panafrican structure reactivated during the Cenozoic Hoggar volcanism (Dautria and Lesquer, 1989; AïtHamou and Dautria, 1994). For this work, we divided this area into two subareas (Supplementary data 1): (1) the North In-Tedeini (NIT) that includes serpentinite massifs of Aderniba and In-Aghabir localities (Fig. 2a); (2) the South In-Tedeini (SIT) that comprises massifs of serpentinites scattered into Iharhi, Amded, Tibehaouine and In-Tamerouelt localities (Fig. 2b). These massifs consist of strongly dismembered ultramafic tectonic slices hosted by magmatic and sedimentary sequences. The only study previously performed on these serpentinites concerns the investigation of a chromitite pod and its surrounding serpentinized outcrop, in south Aderniba locality (Figs. 1c and 2a; Abed, 1983; Augé et al., 2012). Through petrography and mineral chemistry, these authors suggested the presence of an oceanic depleted mantle related to an ophiolite succession.

\section{Sampling and analytical methods}

In the In-Tedeini domain, 110 samples were collected, among them 55 representative serpentinite samples were selected for a detailed investigation. From this set, 65 polished thinsections have been prepared for microscopic study. In the North and South In-Tedeini units, 33 samples were selected (20 and 13 samples, respectively) for whole-rock analyses. Two $100 \mathrm{~g}$ splits of each sample were powdered in an agate pulveriser (pulvérisette 2 Fritsch) to a rather 
homogeneous grain size of 10-20 $\mu \mathrm{m}$. The equipment was thoroughly cleaned between samples processing to avoid cross-contamination.

To determine serpentine varieties, Raman spectroscopy analyses were performed using a Renishaw's inVia Raman spectrometer at Laboratoire Charles Coulomb (University of Montpellier, France). Single scan measurements were generated using a $532 \mathrm{~nm}$ excitation laser focused through a 50X LWD objective (Leica), a signal on 2400 lines/mm grating and a CCD (charge-coupled device) camera detector. Spectra were acquired at $100 \%$ laser power for 5 to 15 seconds exposure time. For the calibration of the system, we used the $520 \mathrm{~cm}^{-1}$ Raman peak of silicon before each measurement session. The spectral acquisition region extends from 100 to 1200 $\mathrm{cm}^{-1}$ that are representative of the vibrational mode characteristic of the low frequency (Si-O) and from 3600 to $4000 \mathrm{~cm}^{-1}$ that characterize the high frequency $(\mathrm{O}-\mathrm{H})$ regions, referring to the literature (Rinaudo et al., 2003; Andreani, 2003; Auzende et al., 2004; Groppo et al., 2006; Debret, 2013; Schwartz et al., 2013; Petriglieri et al., 2015; Lafuente et al., 2016). The baseline subtraction was performed for each spectrum after a proper cosmic ray removal, using the Wire 4.2 Raman software. The graphic assignment of the band position and the full width of the spectra proceeded via Igor Pro7 as shown in Figure 8.

Chemical element distribution maps of Chromian spinel grains were performed by energy dispersive X-ray spectrometry (EDS) X-MaxN 20 $\mathrm{mm}^{2}$ combined to Electron backscatter diffraction (EBSD) on a CamScan X500FE CrystalProbe Scanning Electron Microscope (SEM) at the EBSD national facility of Geosciences Montpellier (University of Montpellier). Chemical mapping of $\mathrm{Cr}, \mathrm{Al}$ and $\mathrm{Fe}$ are presented in this study.

Major element contents in serpentines and spinels (Supplementary data 2 and 3) were obtained using an Electron Probe Micro-Analyser (EPMA) on a CAMECA-SX100 instrument equipped with five wavelength-dispersive X-ray spectrometers (WDS) at the Microsonde Sud facility (University of Montpellier). The analytical conditions comprised a $20-\mathrm{kV}$ accelerating voltage, a focused beam of $10 \mathrm{nA}$ and 20-30s counting times for each analysed element. The XPHI quantification procedure (Merlet, 1994) was used to acquire concentrations from raw intensities. The quality of analyses was calibrated in a suitable program for each mineral using internal standards: $\mathrm{Al}$ on $\mathrm{Al}_{2} \mathrm{O}_{3}$; $\mathrm{Si}$, Ca on Wollastonite; $\mathrm{Ti}$ on $\mathrm{TiO}_{2} ; \mathrm{Cr}$ on $\mathrm{Cr}_{2} \mathrm{O}_{3}$; $\mathrm{Na}$ on Albite; $\mathrm{Mg}$ on Forsterite; $\mathrm{Fe}$ on $\mathrm{Fe}_{2} \mathrm{O}_{3}$; $\mathrm{Mn}$ on $\mathrm{Mn}$ and Rhodonite; $\mathrm{Ni}$ on $\mathrm{Ni}$; $\mathrm{F}$ on LiF; $\mathrm{Cl}$ on Apatite-Cl; 
$\mathrm{K}$ on Orthose. Total iron content obtained by the microprobe is considered as FeO. Ferric and ferrous iron contents were determined assuming stoichiometric compositions (Droop, 1987).

Major element contents in whole rocks (Supplementary data 4) were analysed by inductivity coupled plasma-optical emission spectroscopy ICP-OES at CRPG-SARM (Nancy, France). Trace element concentrations were determined by a high resolution inductively plasma mass spectrometer (ICP-MS) using a quadrupole HP7700X system at Geosciences Montpellier, following an acid digestion procedure described by Ionov et al. (1992) and adapted by Godard et al. (2000) for the analysis of ultra-depleted peridotites. Indium and Bismuth were used as internal standards during ICP-MS measurements. Precision and accuracy of the ICP-MS analyses were assessed from the results obtained for the five USGS reference materials: BE-N, serpentinite UBN, BIR-1, BHVO-2, DTS-1 and blanks (Supplementary data 4).

In situ U-Pb dating of zircons were performed by LA-ICP-MS at Macquarie GeoAnalytical (MQGA, Macquarie University), using the method described by Jackson et al., (2004) and Gain et al., (2019). The LA-ICP-MS platform used consists of an Excite Photon Machines Excimer 193 nm laser system coupled to an Agilent 7700 quadrupole ICP-MS instruments. Analyses were carried out with a beam diameter ranging between $20-40 \mu \mathrm{m}$, using a $5 \mathrm{~Hz}$ repetition rate and a constant energy density ca $7 \mathrm{~J} \bullet \mathrm{cm}^{-2}$. A very fast scanning data acquisition protocol was employed to minimise signal to noise ratio. The isotopes monitored by ICP-MS were ${ }^{206} \mathrm{~Pb},{ }^{207} \mathrm{~Pb},{ }^{208} \mathrm{~Pb}$, ${ }^{232} \mathrm{Th}$ and ${ }^{238} \mathrm{U}$, and the operating conditions were optimised to minimise oxide formation $\left({ }^{248} \mathrm{ThO}^{+} / 232 \mathrm{Th}^{+}<1 \%\right)$, while obtaining maximum sensitivity on $\mathrm{Pb}$ and $\mathrm{U}$. Data acquisition for each analysis took three minutes (one minute on background, two minutes on signal). Provided that constant ablation conditions are maintained, accurate correction for $\mathrm{U} / \mathrm{Pb}$ fractionation can then be achieved using isotopically homogeneous zircon standards. In order to check the validity of dating analyses, samples were bracketed at the beginning and end by pairs of analyses of the GEMOC GJ-1 zircon standard (Elhlou et al., 2006). This standard is slightly discordant, and has a TIMS ${ }^{207} \mathrm{~Pb} /{ }^{206} \mathrm{~Pb}$ age of $608.5 \mathrm{Ma}$ (Jackson et al., 2004). The other well-characterised zircon standard 91500 (Wiedenbeck et al., 1995, 2004) and Mud Tank (Gain et al., 2019) were analysed within the run as an independent control on reproducibility and instrument stability. U-Pb ages were calculated from the raw signal data using the online software package GLITTER (Griffin et al., 2008). The results, as well as the operational conditions for $\mathrm{U}-\mathrm{Pb}$ dating, are listed in Supplementary data 5. 


\section{Results}

\subsection{Field data}

The serpentinite occurs as elongated NNW-SSE asymmetric lenses (Fig. 3a, b), and their sizes vary mostly between $\sim 0.3$ to $2.3 \mathrm{~km}$ in length and $\sim 0.1$ to $0.75 \mathrm{~km}$ in width. The exception is the Aderniba serpentinite body, the largest occurrence of ultramafic rocks in the Hoggar (Augé et al., 2012), which extends over more than $\sim 70 \mathrm{~km}$ in length with a width of about $\sim 1.5 \mathrm{~km}$ in its central part. The studied outcrops consist of massive serpentinites in the core, which exhibit a brownish-black color in North In-Tedeini to greenish-black and black color in South In-Tedeini. They contain spinels (chromite and magnetite) and carbonates clustered in pockets or veinlets, and occasionally sparse chromitite pods (Augé et al., 2012). Some serpentinite outcrops from the Tibehaouine and In-Aghabir localities (Fig. 2a, b) enclose decimetric brownish-black serpentinite enclaves contrasting with their hosting greenish-black serpentinites (Fig. 3c).

The nature of the surrounding rocks is variable. Aderniba serpentinites lie between dismantled magmatic formations, and sandstone-pelitic formations (Figs. 1c and 2a). The Tibehaouine serpentinites are intercalated among sandstone-pelite and pelitic limestone rocks, and dismantled magmatic sequences (Figs. 1c and 2b). Magmatic formations are mainly Neoproterozoic tholeiites, oceanic arc-related basalts, gabbros and andesites previously described by some authors (Chikhaoui et al., 1980; Dupont et al., 1987; Bechiri-Benmerzoug, 2012; Bechiri-Benmerzoug et al., 2017). Most of the magmatic surrounding sets of North and South InTedeini serpentinites show epidotitic-amphibolite assemblages, which support amphibolitic metamorphic conditions along a 15-20 km wide zone that surrounds the serpentinite outcrops. Outside this zone, the surrounding rocks have undergone greenschist-facies metamorphic conditions. Many granitoid plutons, gabbroic and basaltic dikes intruded both serpentinites and their surrounding rocks in the study area.

Talc-schists are ubiquitously associated with all In-Tedeini serpentinites outcrops. They occur as sharp, thin and irregular ductile shear zones in the cores; and they form a thick zone along the margins of the serpentinite bodies (Fig. 3b). The talc-schists are strongly foliated and materialize the structural contact between the massive serpentinites and the surrounding magmatic and sedimentary rocks. These zones are accompanied by greenish-blue foliated serpentinites that 
form a lenticular pattern (Fig. 2c and 3b) with a network of carbonate (and rare quartz) veinlets, and rare breccia that contain fragments of serpentinites within a carbonate-talc matrix.

Since the studied area is largely hidden by sand covers, we focussed our fieldwork on the best exposed serpentinite massifs, Aderniba principally and In-Aghabir in North In-Tedeini, and, Tibehaouine and In-Tamerouelt in South In-Tedeini, where clear relations between the different rock-types were observed (e.g., Figs. 5 and 6). Structural data were collected to characterize the deformation that affected the studied area, they are summarized in Figure 4. Foliation, mineral lineation or evidence of deformation have not been observed in the massive serpentinites.

At the contact with the massive serpentinites, the talc-schists display a well-developed, anastomosing S-C fabric, marked by subvertical to steeply dipping foliation associated to mainly subhorizontal stretching lineation (Figs. 4a, b, e, $\mathbf{f}$ and $\mathbf{6 b}$ ). The talc-schists contain asymmetric lenses of talc as well as pieces of both quartzites and massive serpentinites (Figs. 5a, b; 6c to $\mathbf{g}$ ). Some serpentinite lenses in this zone suggest a top to the NW sense of shear within a moderate SE-dipping foliation (Fig., 5a, b). The structural characteristics documented at this contact characterize a NNW (dominantly) to NNE-striking shear zone (Figs. 3, 4, 6) including dominant sinistral strike-slip shearing and minor NW-thrusting. In fact, as observed at the outcrop scale as well as on satellite images, the talc-schist wraps all the studied massifs of serpentinite; their structure mimics the lensoidal shape of serpentinites elongated in the NNW to NNE directions (Fig. 3a) and reflects the sinistral sense of shear of the asymmetric lenses.

Along the contact with the surrounding rocks in North In-Tedeini localities, the shear zone network is consistent with the pattern of the penetrative foliation in the talc-schists and the country rocks; both foliation and shear planes are subvertical to steeply dipping principally to the NE, and subordinately towards SW (Figs. 2a, c, 4a and 6a). The low obliquity to parallelism of the C-S planes in the shear zones point to a strong deformation at the Aderniba locality, which may account for the lenticular shape of the serpentinite massifs. The associated stretched lineation varies between vertical and horizontal (Figs. 4b and 6a), which supports the co-existence of horizontal and vertical movements in this zone, i.e., a transpressional strain regime. The axial-planes of folds observed in the surrounding rocks, principally eastward of the Aderniba serpentinite massif, are vertical to subvertical in most cases but some are moderately dipping toward the east in association with westward thrusting (Fig., 5d, e, f). These axial-planes are oriented parallel to the foliation in 
the shear zones (Figs. 4a, $\mathbf{c}$ and 5e, f) and the associated fold axes display horizontal to vertical plunges (Fig. 4d).

In the South In-Tedeini domain, the NW-SE to NNE-SSE penetrative foliation and sinistral shear zones observed along the contact between the talc-schist and the surrounding rocks show steep to moderate E to NE dips and more seldom vertical ones (Figs. 4e and $6 \mathbf{h}$ ). The obliquity of the foliation relative to the C-planes in the shear zones supports a thrust tectonic towards west. The associated stretching lineation varies between horizontal and vertical, with a plunge dominantly toward the east to southeast (Fig. 4f). The axial planes of the asymmetric folds (oriented N-S to NW-SE) within the shear zones (Figs. $\mathbf{4 g}$ and 5c), are vertical to moderately dipping eastward to the northeastward; they are broadly compatible with westward thrusting. The fold axes, strongly to moderately plunging towards the NE to NNE, are oblique to the direction of the stretching lineations (Fig. 4f, h). The rotation of the fold axes from NE to NNE (Fig. $4 \mathbf{h}$ ) is compatible with a sinistral strike-slip component.

The orientation of the tectonic structures documented in the field (i.e., in North and South In-Tedeini localities) are compatible with an overall WSW-ENE shortening direction (Fig. 4, 5 and 6). Laterally, it records principally a sinistral strike-slip movement along the contact between the massive serpentinites and the talc-schist to the contact with the surrounding rocks where the fabrics rather support a W-thrusting tectonics. All together reflect a transpressional strain regime in this zone (Figs. 3 to 6), combining horizonal shearing and compressional deformation (e.g., Tikoff and Greene, 1997; Fossen and Tikoff, 1998).

At the scale of the studied area, the formations that surround the serpentinite bodies display an intricate tectonic framework (Fig. 2). An anastomosed subvertical foliation to a moderately eastern-dipping one characterize most part of the studied area. In general, this foliation trends predominantly NNW-SSE, i.e., parallel to the regional scale elongation of serpentinite bodies, and, at a larger scale, to the tectonic fabric already described in the Hoggar as a Panafrican inheritance (Figs. 1, 2 and 4). However, approaching the Amded shear zone in the south of the study area (Fig., 2b), this foliation curves progressively to the ENE-WSW direction. There, this foliation is vertical to subvertical (steeply southward or northward dipping), and contains strongly plunging lineations. All these structures are crosscut by a late stage network of carbonate-filled normal brittle-faults, which are oriented between N032 and N130 directions. 


\subsection{Petrography}

\subsubsection{Serpentinites}

At the thin-section scale, North and South In-Tedeini serpentinites consist exclusively of fine- to medium-grained undeformed serpentine matrix with some pseudomorphic textures (Fig. 7a, b). Vibrational Raman spectroscopy and microscopic observations identify antigorite as the most common serpentine phase in the matrix of all studied serpentinites (Fig. 8). At Si-O low wavenumber Raman region (Fig. 8a), antigorite is distinguished by the occurrence of strong peaks at $230,379,683 \mathrm{~cm}^{-1}$ and a specific one at $1045 \mathrm{~cm}^{-1}$. It is also characterized by a large and intense band at 3671 and then at $3700 \mathrm{~cm}^{-1}$ in the $\mathrm{OH}$ high wavenumber Raman vibration (Fig. 8b). In some Raman spectra, peaks at 1105 and $345 \mathrm{~cm}^{-1}$ as well as $1096 \mathrm{~cm}^{-1}$, classically attributed to Chrysotile and Lizardite, respectively, are detected in addition to the peak at $1045 \mathrm{~cm}^{-1}$ (as in antigorite) at low frequency, which indicate a mixed Antigorite-Chrysotile/Lizardite assemblage. At high frequency region, the second antigorite peak at $3700 \mathrm{~cm}^{-1}$ is still observed for this assemblage, but the peak at $3671 \mathrm{~cm}^{-1}$ is shifted to $3649 \mathrm{~cm}^{-1}$ attributed to Chrysotile and to 3675 $\mathrm{cm}^{-1}$ in intermediate position between the strong antigorite and lizardite peaks. This high temperature variety of serpentine occurs as interpenetrated orthogonal blades (Fig. 7c) that show intense yellow-orange color mainly in the samples from North In-Tedeini and gray-yellow color in those from South In-Tedeini. Lizardite and chrysotile occur in subordinate amounts and mixed with antigorite presenting a dark interlocking texture. Rare small serrate veinlets of antigoriteChrysotile/Lizardite assemblage crosscut antigorite blades in the matrix of some samples (Fig. 7d).

In spite of intense serpentinization, some pseudomorphs of the original minerals are preserved in the matrix of the massive serpentinites: bastites are recognized as pseudomorphs of orthopyroxene porphyroclasts and neoblasts through traces of their original cleavages, highlighted by alignments of magnetite grains (Fig. 7b); original olivine grains are also inferred from a cracked granular shape of pseudomorphs coated with iron oxides (Fig. 7a).

Chromian spinel (Cr-spinel) and magnetite (Fig. 7f) are present in all studied serpentinites as well as in the talc-schists that wrap the massive serpentinite. At thin-sections, the Cr-spinels appear as small euhedral to subhedral cracked grains $(\sim 200-900 \mu \mathrm{m})$ of black or bloody red color. They are usually rimmed (sometimes discontinuous rims) by thin ferrichromites and/or magnetite 
coronas. Magnetite is also abundant as large grains $(\sim 0.01-1 \mathrm{~cm})$ disseminated throughout the matrix, also in veins and, as mentioned above, underlining the cleavage and shape of pseudomorphs.

Optic reconstruction of textures and estimated modal compositions using thin-sections suggest that the studied serpentinites are derived from coarse-grained to porphyroclastic mantle harzburgites (Fig. 7a, b).

Talc occurs only in talc-schist, which, as mentioned in the previous section (i.e., § 4.1), are located at the periphery of serpentinite bodies and in some fractures across these bodies. Talc shows a fine fibrous texture and may appears as dense elongated aggregates in a foliated matrix that contains cracked Cr-spinel grains and magnetite veins. Rare relicts of antigorite are preserved in some talc-schist samples (Fig. 7e). Carbonates are also present in serpentinites and talc-schists. In the serpentinites, they occur mainly as subhedral to anhedral magnesite aggregates $(\sim 0.01-0.1$ $\mathrm{mm}$ ) or in the form of rare veinlets crosscutting the serpentinite matrix. Subhedral and euhedral dolomite and calcite grains $(0.05-0.2 \mathrm{~mm})$ are present in the talc-schists and in few serpentinite samples (i.e., TB-16B and AD-3).

\subsubsection{Chloritite}

Green chloritites were collected in serpentinite outcrop of the North and South In-Tedeini unit (Fig.3d). They have similar aspect in the field, and occur as black dikes crosscutting the massive serpentinite cores. They may crop as three or four parallel intrusions spaced a few metres apart, but many of these intrusions extend in a number of different directions. They are characterized by decimetric to metric width along restricted exposures, and usually exhibit talcschist and clusters of magnetites along the edges (Fig. 3d). At thin-section, the chloritites consist of fine-grained to medium-grained equigranular matrix of clinochlores (up to $5 \mathrm{~mm}$ ), accompanied by euhedral (up to $2 \mathrm{~cm}$ ) and thin veinlets of magnetites (Fig. 7g). Minor rutile, titanite, apatite,

monazite and zircon grains were also observed in the chloritites. In-situ analyses on the latter will be presented below.

\subsection{Mineral chemistry}

\subsubsection{Serpentine}


Electron microprobe analyses of serpentines attest that antigorite is the main serpentine specie in all the sampled serpentinites, consistently with Raman spectra data. Antigorites plot in the end-member of antigorite compositions field, showing a range of Si (1.94-2.08), Al (0-0.12) and $\mathrm{Mg}$ (2.42 - 2.69) cation contents. On the Al vs. Si diagram (Fig. 9e), they plot essentially in the metamorphic field of amphibolite-facies antigorite compilation (see Padron-Navarta et al., 2013; Schwartz et al., 2013). They can be identified as high pressure and temperature Si-rich antigorites as shown by Wunder et al. (2001). The analysed antigorites display a range of $\mathrm{Cr}$ and $\mathrm{Ni}$ content from 0.002 to 0.02 cation contents, respectively; these analyses identify antigorite compositions derived from olivine and orthopyroxene (Kodolányi et al., 2012).

\subsubsection{Chromian Spinel}

For this study, we only considered the preserved spinel cores of the least altered grains; correspondent analyses are available in Supplementary data 3. These cores show the presence of preserved chromian spinel (Cr-spinel) compositions in most of the serpentinites from both units (i.e., North and South In-Tedeini), as well as in talc-schist rock. This is consistent with the petrographic observation and the back-scattered electron imaging studies, which show characteristic shape and colour contrast, as well as specific chemical distribution between the cores and rims (Fig. 7f). These cores display a homogeneous range of compositions, with a high Cr\# number cationic ratio $[\mathrm{Cr} /(\mathrm{Cr}+\mathrm{Al})=0.55-0.6]$, low to intermediate $\mathrm{Mg \#}$ number cationic ratio $\left[\mathrm{Mg} /\left(\mathrm{Mg}+\mathrm{Fe}^{2+}\right)=0.36-0.65\right]$ (Fig. 9b) and very low $(<0.1 \mathrm{wt} \%) \mathrm{TiO}_{2}$ contents (Fig. 9c). Crspinels from the Aderniba talc-schist display a similar range of $\mathrm{Mg \#}$ but with a slightly higher $\mathrm{Cr} \#$ (average $=0.62)$ than those from serpentinites. These compositions are similar to the mantle chromites defined by Franz and Wirth (2000) (Fig. 9a, d) and point to a highly depleted harzburgitic protolith after $\sim 18-28 \%$ of melt extraction (Fig. 9b, c). They plot in all diagrams (Fig. 9b, c, d) in the overlap area between the harzburgitic mantle wedge field principally and the end-member of abyssal peridotites field.

\subsection{Whole rock compositions}


Whole-rock major and trace element compositions are provided in Supplementary data 4 for thirty-three (33) serpentinites, one (1) talc-schist and (3) chloritites.

\subsubsection{Serpentinites and talc-schist}

\subsubsection{Major elements}

The serpentinites from North In-Tedeini exhibit loss on ignition (L.O.I.) in the range 12.34 - $17 \mathrm{wt} \%$, with the exception of sample SAM-33B that reaches $20.69 \mathrm{wt} \%$. Those from South InTedeini show somewhat lower values, mostly in the range $11.02-13.26 \mathrm{wt} \%$, except for the enclave sample (TB-16B, Fig. 3c) that reaches $15.33 \mathrm{wt} \%$. The contents of major oxides were recalculated on an anhydrous basis for comparison with similar rocks from different geological settings (Figs. 10, 11and 12). As illustrated on the $\mathrm{MgO}-\mathrm{SiO}_{2}$-L.O.I. ternary diagram (Fig. 10), the In-Tedeini samples show only a slight variation of the $\mathrm{SiO}_{2} / \mathrm{MgO}$ ratio over a wide range of L.O.I. values and fall within the field of mantle rocks as delineated by forsterite and enstatite compositions (Bucher and Grapes, 2011). This supports that $\mathrm{Si}$ and $\mathrm{Mg}$ were immobile or only mildly mobilized during serpentinization, as already demonstrated by previous studies (Bogolepov, 1970; Coleman and Keith, 1971; Komor et al., 1985; Mével, 2003; Deschamps et al., 2013). These elements can therefore be used to retrieve information on the composition of the mantle protolith. In both units, the $\mathrm{MgO}$ content (42.54 - $49.87 \mathrm{wt} \%$ in NIT, and $40.87-47.03$ wt\% in SIT serpentinites; Fig. 11), as well as the Mg\# number cationic ratio (100 $\mathrm{x} \mathrm{Mg} \mathrm{/}(\mathrm{Mg}+$ $\mathrm{Fe})=88.6$ - 93.9 in NIT and 85.3 - 93.5 in SIT serpentinites) span a large part of mantle rock compositions including highly refractory peridotites (harzburgites and dunites - Workman and Hart, 2005; Bodinier and Godard, 2014).

Compared to primitive mantle (McDonough and Sun, 1995), the In-Tedeini serpentinites are strongly depleted in $\mathrm{Al}_{2} \mathrm{O}_{3}\left(0.15-1.37 \mathrm{wt} \%\right.$, Fig. 11a) and $\mathrm{TiO}_{2}(0.002-0.005 \mathrm{wt} \%$ in NIT and $0.002-0.02$ wt\% in SIT, Fig. 11b). On the Mg/Si vs. Al/Si diagram (Fig. 12), they plot towards the high $\mathrm{Mg} / \mathrm{Si}$ - low $\mathrm{Al} / \mathrm{Si}$ end of the Melting Residue trend. On both $\mathrm{Al}_{2} \mathrm{O}_{3}$ and $\mathrm{TiO}_{2}$ vs. $\mathrm{MgO}$ diagrams (Fig. 11a, b), as well as on the $\mathrm{Mg} / \mathrm{Si}$ vs. $\mathrm{Al} / \mathrm{Si}$ diagram (Fig. 12), the studied serpentinites fall within the field of mantle wedge fresh and serpentinized peridotites (i.e., IzuBonin Mariana type). The talc-schist sample is however distinguished by lower $\mathrm{MgO}$ content and an anomalously low $\mathrm{Mg} / \mathrm{Si}$ value, outside the field of mantle peridotites, a feature that may be explained by local $\mathrm{SiO}_{2}$ enrichment during serpentinization (e.g., Snow and Dick, 1995; Niu, 
2004; Bach et al., 2004; Paulick et al., 2006; Kodolányi et al., 2012; Boschi et al., 2013; Harvey et al., 2014; Malvoisin, 2015).

Finally, the studied serpentinites show a wide range of $\mathrm{CaO} / \mathrm{Al}_{2} \mathrm{O}_{3}$ values, spanning over more than two orders of magnitude (from 0.06 to 5.86 in NIT and from 0.04 to 4.01 in SIT) and probably unrelated with fertility degree (Fig. 11c). This feature is hardly consistent with mantle compositions and rather suggests some redistribution of calcium during serpentinization or late alteration (Miyashiro et al.,1969; Coleman and Keith, 1971; Janecky and Seyfried, 1986; Palandri and Reed, 2004; Iyer et al., 2008; Mothersole et al., 2017). The high $\mathrm{CaO} / \mathrm{Al}_{2} \mathrm{O}_{3}$ ratio (22.18) of the talc-schist (AD-10), in particular, can be unambiguously related to an interaction with Ca-rich fluids during a carbonation process as dolomite $\left(\mathrm{CaMgCO}_{3}\right)$ and calcite $\left(\mathrm{CaCO}_{3}\right)$ are abundant in this sample. This will be further explored in the discussion section.

\subsubsection{Trace elements}

The In-Tedeini serpentinites are depleted in trace elements relative to chondrites and primitive mantle (Fig. 13). Marked differences are however observed between the North and the South In-Tedeini units, as clearly shown by chondrite-normalized (CN) rare earth element (REE) patterns (Fig. 13a, c). Except for one sample (SAM-33B), the North In-Tedeini serpentinites show concave-upward patterns that characterize a strong depletion of middle REE (MREE) with $\mathrm{Gd}_{\mathrm{CN}}$ contents $=0.006-0.05$, whereas the light and heavy REE (LREE and HREE) are less depleted with $(\mathrm{La} / \mathrm{Gd})_{\mathrm{CN}}$ and $(\mathrm{Gd} / \mathrm{Lu})_{\mathrm{CN}}$ ratios $=1.65-12.97$ and $0.04-0.29$, respectively. Except for the enclave sample TB-16B, the SIT serpentinites are comparatively less depleted in MREE and show relatively steady $\mathrm{REE}_{\mathrm{CN}}$ patterns, marked by gradual enrichment from HREE to LREE with $(\mathrm{La} / \mathrm{Yb})_{\mathrm{CN}}$ ratios $=1.20-6.84$. The sample SAM-33B from the NIT suite is distinguished from the other NIT serpentinites from the same unit by relatively steady enrichment from HREE to LREE, and as such resembles the SIT suite. It is however distinguished from this latter by a positive Eu anomaly $\left[\delta \mathrm{Eu}=(\mathrm{Eu} / \sqrt{\mathrm{Sm} \times \mathrm{Gd}})_{\mathrm{CN}}\right]$ which is more akin to the NIT suite. Conversely, the enclave sample TB-16B from the South In-Tedeini unit is depleted in MREE and shows a concave-upward REE $_{\mathrm{CN}}$ pattern comparable to those observed in the NIT serpentinites.

The two serpentinite units also differ from each other with respect to $\mathrm{Eu}$ and $\mathrm{Ce}$. While the North In-Tedeini serpentinites show either negative or positive $\mathrm{CN}$ Eu anomalies $(\delta \mathrm{Eu}=0.38$ - 
$2.63)$ in some samples, and generally lack significant $\mathrm{Ce}$ anomaly $\left[\delta \mathrm{Ce}=(\mathrm{Ce} / \sqrt{\mathrm{Sm} \mathrm{x} \mathrm{Gd}})_{\mathrm{CN}}\right]$, the South In-Tedeini serpentinites are distinguished by the presence of both Eu and Ce negative anomalies in most samples, with $\delta \mathrm{Eu}=0.28-0.82$ and $\delta \mathrm{Ce}=0.20-0.88$. It is worth noting that the talc-schist (i.e., sample AD-10) is distinctively enriched in $\mathrm{Eu}(\delta \mathrm{Eu}=40.4)$ and also differ from the associated NIT serpentinites by lesser MREE depletion and a somewhat flatter CN REE pattern (Fig. 13a).

On the extended primitive mantle-normalized diagram (PM-N, Fig. 13b, d), the In-Tedeini serpentinites are predominantly characterized by prominent spikes of $\mathrm{Ba}, \mathrm{U}, \mathrm{Pb}$, and $\mathrm{Sr}$ relative to neighbouring elements, as well as selective enrichments of $\mathrm{Cs}$ relative to $\mathrm{Rb}$ and Li relative to HREE. A slight difference is observed between the North and South In-Tedeini units with respect to $\mathrm{U}$ and $\mathrm{Pb}$ : while the former tends to be more enriched in $\mathrm{Pb}$, with $(\mathrm{Pb} / \mathrm{Pr})_{\mathrm{PM}-\mathrm{N}}=53-352$ compared with 1.4 - 62 in the later, the SIT unit tends to be more enriched in U, with (U/Th) PM-N $=1.76-118$ compared with $0.35-56$ in the NIT unit. On the other hand, the enrichments in Ba and $\mathrm{Sr}$ are comparable in the two units, with $(\mathrm{Ba} / \mathrm{Rb})_{\mathrm{PM}-\mathrm{N}}$ and $(\mathrm{Sr} / \mathrm{Nd})_{\mathrm{PM}-\mathrm{N}}$ ratios reaching 1584 and 125, respectively, in NIT, and 473 and 140 in SIT. A noticeable exception is the talc-schist (sample AD-10) which is strongly enriched in $\mathrm{Sr}$, with $(\mathrm{Sr} / \mathrm{Nd})_{\mathrm{PM}-\mathrm{N}}=1446$.

In both units, the high field strength elements (HFSE) are variably fractionated relative to $\mathrm{REE}$, the largest variation range being observed for $\mathrm{Nb}$ in $\mathrm{NIT}\left[(\mathrm{Nb} / \mathrm{La})_{\mathrm{PM}-\mathrm{N}}=0.1-13.4\right]$. A negative anomaly is observed for Y relative to overall trend of HREE in all NIT samples $(\delta \mathrm{Y}=(\mathrm{Y}$ $\left./ \sqrt{\operatorname{Er} \times \mathrm{Tm}})_{\mathrm{PM}-\mathrm{N}}=0.41-0.76\right)$ as well as in the REE-depleted enclave sample $(\mathrm{TB}-16 \mathrm{~B})$ and in the two most REE-depleted serpentinites from the South In Tedeini suite (TB-22 and TB-16A). Such Y depletion has been previously reported from abyssal and mantle wedge serpentinized harzburgites and dunites (Deschamps et al., 2013). The 'U-shaped' pattern observed in the NIT serpentinites and the enclave sample from SIT (TB-16B), on both REE and trace elements diagrams (Fig. 13a, b) lie on the field of refractory mantle peridotites (McDonough and Frey, 1989; Bodinier and Godard, 2014). It is notably observed in mantle wedge fresh and serpentinized peridotites (i.e., Izu-Bonin Mariana; Parkinson and Pearce, 1998; Savov et al., 2005a, 2007; Kodolányi et al., 2012). In contrast, the trace-element pattern observed in the South In-Tedeini serpentinites is less common in refractory peridotites and overlaps the fresh and serpentinized abyssal peridotite fields and the enriched ones of mantle wedge setting on Figure 
13. Similar patterns have been reporded from refertilized abyssal peridotites (e.g., Niu, 2004; Paulick et al., 2006).

\subsubsection{Chloritite}

\subsubsection{Major elements}

The chloritites samples exhibit loss on ignition (L.O.I.) in the range $9.88-12.52 \mathrm{wt} \%$ (see Supplementary data 4). The major oxides contents (recalculated on anhydrous basis) show high $\mathrm{MgO}$ and $\mathrm{Fe}_{2} \mathrm{O}_{3 \mathrm{~T}}$ (29.09 - $37.40 \mathrm{wt} \% ; 7.03$ - $17.7 \mathrm{wt} \%$, respectively) content with $\mathrm{Mg \#}=77.4$ 91.3. It records relatively low $\mathrm{SiO}_{2}(26.97-34.55 \mathrm{wt} \%), \mathrm{Al}_{2} \mathrm{O}_{3}$ (14.42 - $\left.20.56 \mathrm{Wt} \%\right), \mathrm{CaO}(0.04-$ $3.26 \mathrm{wt} \%)$ and $\mathrm{TiO}_{2}(0.05-4 \mathrm{wt} \%)$ contents.

\subsubsection{Trace elements}

The sampled chloritites show enriched trace elements patterns relative to chondrite and MORB (Fig. 14a). They display relatively flat $R E_{C N}$ patterns, marked by gradual enrichment from HREE to LREE with $(\mathrm{La} / \mathrm{Yb})_{\mathrm{CN}}$ ratios $=30.22-183.80$. A slight negative Eu anomaly is marked in the samples. On MORB-normalized diagram, the chloritites show significant and gradual enrichment in $\mathrm{Th}, \mathrm{U}, \mathrm{Pb}$ and $\mathrm{Ti}$, with important $\mathrm{Nb}$ - $\mathrm{Ta}$ tough compared to $\mathrm{Zr}$-Hf. The studied samples show similar depletion on $\mathrm{Cs}, \mathrm{Rb}, \mathrm{Ba}$ and $\mathrm{Sr}$.

The variable enrichment of trace elements and some major elements in the studied chloritites reflect the variable abundance of magnetites, Ti-rich minerals, apatites, monazites and zircons in these rocks. These minerals are possibly the main reservoirs of principally Fe, LREE, $\mathrm{Th}, \mathrm{Nb}, \mathrm{Ta}$ and $\mathrm{Zr}$ in the chloritites.

\subsection{Zircon U-Pb ages}

Only two zircons were detected and recovered from the chloritite sample SAM-8 of south Aderniba serpentinites (Figs. 7g and 14a; Supplementary data 4). We report in-situ U-Th-Pb analytical data on cores of these grains. The two zircons (65 and $200 \mu \mathrm{m})$ show euhedral and 
colourless shape with rounded edges (Figs. 7g and 14b), and few oscillatory zonings. They do not show any evidence for inheritance from older cores or the presence of mineral inclusions. Isotopic data yield concordant ${ }^{206} \mathrm{~Pb} /{ }^{238} \mathrm{U}-{ }^{207} \mathrm{~Pb} /{ }^{235} \mathrm{U}$ core ages (Fig. 14b) of $770 \pm 5 \mathrm{Ma}$ on core of the large zircon $(200 \mu \mathrm{m})$ and $631 \pm 10 \mathrm{Ma}$ on core of the small zircon $(65 \mu \mathrm{m})$.

\section{Discussion}

\subsection{Influence of serpentinization processes on the chemical composition of the In-Tedeini serpentinites}

Before using major- and trace-element compositions of the studied serpentinites to infer the nature and origin of their mantle protolith, it is first necessary to deconvolute the possible effects of serpentinization and further alteration processes on rock chemistry. Most samples are characterized by selective enrichment of certain trace elements that are generally considered as 'fluid mobile elements' (FME: Cs, Ba, U, Pb, Sr, and Li - Fig. 13b, d). Due to their solubility in aqueous solutions, these elements can be strongly affected by serpentinization. When properly decoded, the FME-enrichment signature may even be used as a tool to trace serpentinization conditions and geodynamic settings in which they developed (e.g., De Hoog et al., 2009; Deschamps et al., 2010; 2013; Kodolányi et al., 2012; Debret, 2013; Lafay et al., 2013; Cannaò et al., 2016).

$\mathrm{Li}, \mathrm{Pb}$ and $\mathrm{Cs}$ show positive correlations trending towards the compositional array of marine and subducted sediments (Fig. 15). This suggests that the distribution of these elements in the In-Tedeini serpentinites was chiefly controlled by influx of a sedimentary component. Interaction between refractory peridotites and sediment-derived fluids has been advocated by several authors to explain the FME signature of serpentinites, and is principally considered as a subduction zone signature imprinted in mantle wedge conditions (e.g., Parkinson and Pearce, 1998; Savov et al., 2005a; 2007; Alt and Shanks, 2006; Vils et al., 2008, 2011; De Hoog et al., 2009; Kodolányi et al., 2012; Lafay et al., 2013; Cannaò et al., 2016; Hodel et al., 2019). In this scenario, FME-rich fluids released by dehydration of sediments entrained in the subduction channel with the slab would infiltrate the overlaying mantle wedge, producing enriched serpentinites with specific FME signatures (Hyndman and Peacock, 2003; Deschamps et al., 2013; Lafay et al., 2013; Cannaò et al., 2016; Debret et al., 2018). 
$\mathrm{Ba}, \mathrm{Sr}$ and $\mathrm{CaO}$ also show positive correlations, however trending towards the compositional field of carbonate formations (Fig. 16). This indicates that these elements were at least partly redistributed in the In-Tedeini serpentinites by carbonate-rich fluids, likely through the shear zones that affected the serpentinite bodies (see $§ 4.1$; Fig. 3b) and reflect the precipitation of carbonates in the most enriched samples. The strong enrichment of $\mathrm{Ca}, \mathrm{Sr}$ and Eu observed in the talc-schist sample, from the shear zone, suggests that the inferred fluids were related to the formation and evolution of the talc-zone wrapping the serpentinites. Formation of this reaction zone at the contact with magmatic and sedimentary country rocks is probably favoured by a process involving metasomatism due to the infiltration of $\mathrm{SiO}_{2}$-rich hydrothermal fluids likely associated with, or followed by, carbonate- and iron-rich fluids (e.g., Morishita et al., 2009; Rouméjon et al., 2015; Hodel et al., 2017; Debret et al., 2018, 2020; Wang et al., 2020). Subordinate infiltration of reacted hydrothermal fluids into the serpentinite bodies under variable redox, $\mathrm{pH}$, chlorinity and temperature conditions may have also caused the subtle anomalies of Eu and Ce observed in these rocks (Bau, 1991; Paulick et al., 2006).

Some authors have suggested that L- and MREE may also be mobilized during serpentinization and/or hydrothermal processes, resulting in selective enrichments of these elements relative to HREE and HFSE (e.g., Paulick et al., 2006; Andreani et al., 2014; Hodel et al.; 2018). Selective REE enrichment was also frequently advocated to explain the negative anomalies of $\mathrm{Nb}$-Ta and $\mathrm{Zr}$-Hf relative to REE observed in subduction-related volcanism, as an imprint resulting from fluid-flux melting in supra-subduction mantle wedges (Kelemen et al., 2003a and references therein). In the In-Tedeini serpentinites, secondary REE enrichment cannot be ruled out in the case of sample SAM-33B from NIT, which is more enriched in REE than its counterparts (Fig. 13a) and also shows elevated L.O.I. (20.69\%). However, this sample is also distinguished by the highest $\mathrm{MgO}$ contents (49.87 wt\%), a feature that reflects the presence of substantial amounts of Mg-carbonates (magnesite) in this sample. This suggests that the REE enrichment in this rock is more likely related to the infiltration of carbonated fluids in a late evolutionary stage.

Sample SAM-33B is distinguished on the $\mathrm{Nb} v s$. $(\mathrm{La} / \mathrm{Yb})_{\mathrm{CN}} \operatorname{diagram}($ Fig. 17a) by relatively high $\mathrm{La} / \mathrm{Yb}$ ratio with respect to its $\mathrm{Nb}$ content. Two other samples (SAM-14B from NIT and TB-22 from SIT) also show relatively high $\mathrm{La} / \mathrm{Yb}$ values with respect to $\mathrm{Nb}$ and plot in the field of hydrothermalized peridotites. These three samples therefore represent potential candidates 
for secondary LREE enrichment during serpentinization or hydrothermalism. However, the remaining sample set plots on the positive correlation between $\mathrm{Nb}$ and $\mathrm{La} / \mathrm{Yb}$, which is expected from interaction processes involving silicated mantle melts rather than low-density fluids (You et al., 1996; Kogiso et al., 1997; Niu, 2004; Savov et al., 2005a; Paulick et al., 2006; Deschamps et al., 2013). Thus, the REE systematic observed in these samples is better explained by melt processes under lithospheric mantle conditions.

Finally, we deduce that, apart from $\mathrm{CaO}$ and the FME elements $\mathrm{Cs}, \mathrm{Ba}, \mathrm{U}, \mathrm{Pb}, \mathrm{Sr}$, and $\mathrm{Li}$, as well as the LREE in the three samples SAM-33B, SAM-14B, and TB-22 that were possibly partly enriched in LREE by secondary processes, the major and trace element compositions of the In-Tedeini serpentinites can be used to infer the nature and origin of their mantle protolith, as also the melt processes involved. We therefore focused our investigation (\$ 5.2) on REE and discarded the samples SAM-33, SAM-14B and TB-22.

\subsubsection{Influence of serpentinization processes on the chemical composition of chloritites}

The occurrence of chloritite rocks rimmed by talc formation (Fig. 3d) along with their REE- and alkaline-rich chemical compositions (Fig. 14a) might be a result of a metasomatism or interaction with hydrothermal fluids involving precursor mafic dikes crosscuting the ultramafic rocks; This metasomatism is likely a consequence of the serpentinization processes that affected all the massifs (Morishita et al., 2009). Alkaline hydrothermal alteration of a mafic dike might then resulted in enrichment of Fe and leaching out of $\mathrm{Si}$ and $\mathrm{Ca}$. This would probably induce the formation of chlorite-rich rock in the centre of the dike with magnetite clusters, monazite and apatite, bounded by talc formation that present signs of interaction (Figs. 3d).

However, despite the high enrichment of trace elements (including $\mathrm{Zr}$ ) in the chloritite SAM-8 (Fig. 14a), only two zircons with significant sizes (65 and $200 \mu \mathrm{m})$ were detected. Zircon crystals frequently occurs in mafic dikes intruded into peridotites (eg., Kaczmarek et al., 2007) but it has also been reported in metasomatic chloritites (eg., Arena et al., 2017; Hartmann et al., 2021). Evidence has been presented that zircons may form during metasomatism of harzburgite by basaltic liquid and volatile-rich accompagnying fluids (Griffin et al., 2000; Grieco et al., 2001; Dubinska et al., 2004). Despite the magmatic texture of the two studied zircon crystals (Corfu et al., 2003), the high $\mathrm{Zr}$ content in the SAM-8 whole-rock may be due to its mobilization by CO2- 
rich accompanying fluids and, thus related to a co-precipitation of very small $(<10 \mu \mathrm{m})$ metasomatic zircons in addition to these relatively large two zircons.

\subsection{Protolith fingerprint and melt processes}

\subsubsection{Partial melting and melt extraction}

Low whole-rock major, REE and HFSE concentrations in the studied serpentinites point to a derivation from a highly residual mantle protolith, i.e., harzburgites (Figs. 10 to 13), as also supported by the mineralogical features preserved by the pseudomorphic serpentinization texture (Fig. 7a, b; Streckeisen, 1976; Wicks et Whittaker 1977). Spinels are the only pristine minerals well-preserved from alteration in the In-Tedeini samples. Their compositions showing high Cr\# values $\left(0.55\right.$ - 0.6), low to moderate $\mathrm{Mg \#} \mathrm{ratios} \mathrm{(0.36} \mathrm{-} \mathrm{0.65)} \mathrm{and} \mathrm{very} \mathrm{low} \mathrm{TiO}_{2}$ contents $(<0.1$ wt \%), suggest partial melt extraction in the range $\sim 18-28 \%$ (Fig. 9b, c). Such high melting degrees are considered one of the distinctive imprints of mantle wedge environments, where peridotites experience intense and/or multiple flux melting episodes (Dick and Bullen, 1984; Ishii et al., 1992; Parkinson and Pearce, 1998; Bizimis et al., 2000; Ahmed et al., 2005; Barth et al., 2008; Arai and Ishimaru, 2008; Ulrich et al., 2010; Uysal et al., 2012, 2015, 2016). The mantle wedge setting is also supported by the low $\mathrm{Al}_{2} \mathrm{O}_{3}$ content $(<2.4 \mathrm{wt} \%)$ recorded in bastites (Fig. 9e), pointing to an $\mathrm{Al}$-poor parent orthopyroxene $\left(\mathrm{Al}_{2} \mathrm{O}_{3}<2.9 \mathrm{wt} \%\right)$ indicative of a high degree of partial melt extraction, as reported for Himalaya and Izu-Bonin-Mariana peridotites (Ishii et al., 1992; Parkinson and Pearce, 1998; Hattori and Guillot, 2007).

However, trace elements show significant variations between North and South In-Tedeini serpentinites. Similar to Izu-Bonin Mariana mantle peridotites (Parkinson and Pearce, 1998; Savov et al., 2005a, 2007; Kodolányi et al., 2012), the North In-Tedeini samples show depleted concave-upward $\mathrm{REE}_{\mathrm{CN}}$ patterns and a higher tendency to clustered HREE compared with M- and LREE patterns. In contrast, the SIT samples show more enriched and flatter REE $_{C N}$ patterns, overlapping abyssal mantle peridotites (Niu, 2004; Paulick et al., 2006; Godard et al., 2008; Boschi et al., 2013) and the enriched mantle peridotites from Izu-Bonin Mariana system (Parkinson and Pearce, 1998; Savov et al., 2005a, 2007; Kodolányi et al., 2012). Such variations are generally ascribed to different degrees of partial melting in subduction zones. 
To better constrain the magmatic processes responsible for the geochemical signature of the In-Tedeini serpentinites, we assessed the effects of partial melting and enrichment processes using REE compositions to perform non-modal, closed- and open-system dynamic melting and melt-rock interactions models (Fig. 18; see melting model equations in Zou, 1998). We first applied a closed-system dynamic melting model starting from a depleted mantle source (DM) with a critical mass porosity of the residue set to $\Phi=1 \%$. Model's parameters and numerical results are given in Supplementary data 6. We used HREE contents to determine the degrees of partial melting. Results for the closed dynamic model show that the composition of the North In-Tedeini serpentinites requires 18 - 22\% partial melting of a DM source, while that of the South In-Tedeini serpentinites is explained by slightly lower melting degrees in the range $15-21 \%$. However, the models predict that the melting residues should be strongly depleted in LREE relative to HREE. The L- and MREE systematics observed in the In-Tedeini serpentinites require complementary enrichment processes (e.g., Navon and Stolper, 1987; Ozawa and Shimizu, 1995; Vernières et al., 1997; Godard et al., 2000; Brunelli et al., 2014; Bodinier and Godard, 2014; Warren, 2016), a mechanism that will be considered in the following section.

\subsubsection{Melt-rock interaction processes in the mantle}

$\mathrm{Nb}$ and LREE $(\mathrm{La})_{\mathrm{CN}}$ plotted against $(\mathrm{La} / \mathrm{Yb})_{\mathrm{CN}}$ and $\mathrm{HREE}(\mathrm{Gd} / \mathrm{Yb})_{\mathrm{CN}}$, respectively $($ Fig. 17a, b) show a linear correlation that encompasses both North and South In-Tedeini serpentinites and supports a petrogenetic relationship between the two units. A linear correlation of the highly incompatible elements $\mathrm{Nb}$ and $\mathrm{La} v s$. $\mathrm{La} / \mathrm{Yb}$ or $\mathrm{Gd} / \mathrm{Yb}$ cannot be accounted for by variable degrees of melting. It is more readily explained by the addition of variable amounts of LREE-enriched melt to a depleted mantle protolith (see e.g., the Neoproterozoïc serpentinites of Araguaia (Hodel et al., 2019), the Eastern Desert of Egypt (El Dien et al., 2016) and the Anti-Atlas (Hodel et al., 2020); Fig. 17b). As discussed by Bodinier and Godard (2014), this process may result from the redistribution of partial melts within or atop a molten domain, leading to the refertilization of previously depleted residues. In a subduction setting, the enrichment may also results from opensystem, flux melting, or from infiltration of LREE-enriched melts into mantle wedge peridotites that have experienced earlier stages of melt extraction (Pearce et al., 1995; Parkinson and 
Pearce, 1998; Savov et al., 2005a; Ulrich et al., 2010; Uysal et al., 2012, 2015; 2016; Saha et al., 2018).

In order to assess the potential of these melt-rock interaction processes to account for the observed L- and MREE enrichments, and also evaluate the nature of the enriched component, we first modified our melting model to simulate the effect of an open system dynamic melting involving influx of a slab-derived fluid component. The latter was compiled from Eiler et al. (2000, 2007) and quantified by the mass influx rate $\beta$. The modelling procedure and input parameters are presented in Supplementary data 6 and illustrated in Figure 18. The model allows to roughly reproduce the U-shaped CN signature of the North In-Tedeini serpentinites for melt extraction (F) from a DM source in the range 20 - 22\% and values of the slab-derived fluid influx $\beta$ between 0.005 and $0.05 \%$.

However, this model fails to explain the enrichment in both L- and MREE observed in the SIT serpentinites, which requires further refertilization by a melt component. We modelled then a two-stages process involving (1) flux dynamic of DM to $F=21 \%$ with $\beta=0.05$, and (2) subsequent refertilization of the residue by a melt of primitive island-arc composition. The refertilization model is based on the equation B1 of Hellebrand et al. (2002b), see Supplementary data 6. As refertilizing melt, we used primitive basalt compositions from the spatially associated Silet islandarc volcanic suite (Chikhaoui et al., 1980), at the east of the studied area. Fractions of added melt (X) were in the range $0.02-1.2 \%$.

The results closely reproduce the $\mathrm{REE}_{\mathrm{CN}}$ patterns of the South In-Tedeini unit (Fig. 18). We also run the model with a TTG composition for the melt, also issued from the Silet island arc suite (Bechiri-Benmerzoug, 2012). However, the island-arc basalt yielded a better fit to the REE distribution in the SIT unit. Although significant in terms of REE signatures, the difference between the North and South In-Tedeini units can therefore be explained by refertilization of the latter involving addition of only a very small fraction of LREE-melts (mostly < 1\%). Such a low melt fraction has no detectable influence on major elements nor on moderately incompatible and compatible trace elements (Niu, 2004; Barth et al., 2008). Enrichment by such small melt fractions may also account, at least in part, for the scarcity of mineralogical and textural evidence for refertilization in the In-Tedeini serpentinites - even though the record of these melt-rock interactions has been obscured by the serpentinization. Ulrich et al. (2010) came to the same conclusion in their study on the New Caledonia ophiolite in which the peridotites were interpreted 
to contain 0.01 to $0.1 \%$ of LREE-enriched trapped melt. In contrast, for lherzolites from the northern Fizh block in Oman, which showed clear textural evidence for refertilization, Takazawa et al. (2003) have estimated much higher proportions of MORB-type trapped melt ( 4 to $8 \%$ ).

The overall geochemical signatures of the North and South In-Tedeini units suggest they have experienced similar fluid-induced melting episodes, in a subduction mantle wedge. Thereafter, the evolution of two units has diverged, with the SIT unit recording refertilization by small volumes of LREE-rich melts generated in the mantle wedge. This scenario is corroborated by the serpentinite enclave (sample TB-16B) enclosed in the SIT unit (Figs. 3c and 18). The

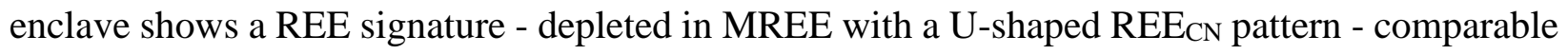
to that of the NIT serpentinites. It might therefore represents a relic of the residual harzburgite before refertilization. Notwithstanding the substantial difference in the degree of refertilization in both settings, this enclave is comparable to the enclaves of highly depleted harzburgites found within the secondary (i.e., refertilized) lherzolite of Lherz (Le Roux et al., 2007).

The divergence observed in the igneous evolution of the two units may reflect a subtle difference in their location within the mantle wedge before cooling and onset of exhumation. The coexistence of both depleted and refertilized peridotites, <1 km apart, has been observed in the subduction-related Ronda peridotite (Lenoir et al., 2001). There, the refertilization was ascribed to infiltration of partial melts in a lithospheric mantle bounding a molten domain. Regarding the In-Tedeini serpentinites, a slight variation in the thermal evolution may account for the diverging geochemical signatures; this variation can be linked to several factors such as (1) the presence of transform faults near the subduction zone, as proposed for peridotites from New Caledonia (Nicolas and Dupuy, 1984; Ulrich et al., 2010), or (2) the entrapment of both units in distinct positions relatively to the convection in the mantle wedge: North In-Tedeini unit cooled at the base of the arc region while South In-Tedeini unit originated from a deeper mantle level.

\subsection{Implication of In-Tedeini serpentinites to geodynamic evolution of the Hoggar and Gondwana assembly}

Our results substantiate that the In-Tedeini serpentinites have preserved the main characteristics of their parent peridotites and derive from a depleted mantle wedge involved in a subduction zone. This subduction would have triggered intense partial melting and refertilization of the involved mantle wedge by magmatic island arc products (Fig. 18). 
Field evidence based on relations between the NNW-SSE elongated serpentinite lenses from North and South In-Tedeini units (Figs. 2, 4, 5 and 6) with deformed magmatic (tholeiite and arc related basalts and gabbros)- and sedimentary (sandstone-pelite, pelitic-limestone) country rocks (Chikhaoui et al., 1980; Dupont et al., 1987; Bechiri-Benmerzoug, 2012; BechiriBenmerzoug et al., 2017) through a talc-schist zone, indicate intense and laterally variable deformation. Indeed, along the contact between the talc-schist and the country rocks, the tectonic fabric is characterized by subvertical and moderately eastern-dipping foliation, well marked in the southern unit, bearing down-dip lineations and asymmetric folds consistent with top-to-west thrusting (Figs. 4, 5c, d). Then, approaching the contact between the talc-schist and the massive serpentinites, the foliation becomes steeply dipping to vertical with a lineation dominantly subhorizontal, pointing to a NNW-SSE horizontal movement motion (Figs. 4, 5a,b and 6). The inferred deformation is compatible with an overall WSW-ENE shortening and suggests that massive serpentinites lenses ascended from the mantle wedge into the crust along major sinistral shear zones assisted by talc-schist that acted as lubricant, which further promoted strain localization of a transpressive deformation in steeply eastward dipping shear zones, between the massive serpentinites and their surrounding formations. The precipitation of talc in the subduction fault zone has been invoked as a key contributor to long-term strain localization (e.g., Escartin et al., 2008a). In this exhumation process, the talc-schist wrapped the massive serpentinites (Fig. 3a, b) that consequently escaped the pervasive deformation observed in the surrounding rocks (Figs. 4, 5 and 6); they have preserved their original antigorite fabric and mineral assemblages through their exhumation history.

Indeed, the current orthogonal antigorite texture of the massive In-Tedeini serpentinites (Figs.7e and 8 ) points to a primary serpentinization in the mantle wedge that mostly occurred under temperature and pressure $\left(\sim 390^{\circ}-<650^{\circ} \mathrm{C}\right.$ and $\sim 9$ - <15 Kbar; Evans, 2004; Schwartz et al., 2013), i.e., essentially in the amphibolite-facies (Fig. 9e) and under static conditions (Wicks et Whittaker 1977). However, the occurrence of lower temperature serpentines (i.e., chrysotile/lizardite-antigorite assemblage) essentially in veinlets, crosscuting the antigorite blades (Fig. 7d) may suggests a later serpentinization in different conditions, which can be related to temperature decrease after the emplacement of In-Tedeini antigoritized-serpentinite in the crust. In addition, the occurrence of rare relicts of antigorites in the talc-schist margin (Fig. 7e) also supports the fact that the talc derived from antigorite origin, which was affected by intense 
temperature-pressure conditions associated to Si-rich hydrothermal fluid interaction derived from sedimentary rocks, more likely during massif exhumation event. Then, the inferred infiltration of FME-rich fluids in the mantle wedge ( $\$ \mathbf{5 . 1})$ would be related to the primary serpentinization, with the exception of carbonate- and iron-rich fluids. The latter are more likely related to a posterior hydrothermal event in the crust and are evidenced by the occurrence of carbonate as well as magnetite clusters and veins crosscutting the matrix of the talc-schist (principally) and serpentinites.

All together, the geological characteristics reported in this work including field, petrological and geochemical data support the presence of an oceanic basin west of the LATEA domain before the Panafrican orogeny and, today, of a NNW-SSE directed suture zone in InTedeini region. This suture zone, previously suggested from geophysical data, is outlined by mantle serpentinite lenses exhumed in a collisional accretionary wedge structure (Fig. 19), similarly to the one developed in front of some arc zones on paleo-subduction settings (e.g., Guillot et al., 2009, 2015; Escuder-Viruete et al., 2011; Kusky et al., 2013). This accretionary prism, today with an average width of $\sim 20 \mathrm{~km}$, combines these mantle remnants with NW- to NEtrending slices of tectono-metamorphic units (including amphibolite-facies metamorphism in the central zone and greenschist conditions outside this zone), which agrees with the Panafrican metamorphic conditions defined by Bertrand and Caby (1978). This paleo-subduction zone is located between the Silet island arcs on the eastern side and the continental platform deposits of the western Hoggar on the western side (Figs. 1 and 19). In such a geodynamic model, likewise, the occurrence of mafic-ultramafic succession in eastern Silet (Fig. 1c; Abed, 1983) would be consistent with an intracontinental rifting that possibly evolved to a restricted seafloor spreading during the Panafrican orogeny (Dupont et al., 1987; Boukhalfa, 2002; Bouchachi, 1993). The presence and spatial proximity of this rifting would corresponds to a backarc basin in this paleosubduction zone (Dilek and Furnes, 2014).

In contrast to some previous work that suggested westward dipping subduction in centralwestern Hoggar (e.g., Caby, 2003; Brahimi et al., 2018; Liégeois, 2019), the tectonic context we propose rather support an oblique NW-SE Panafrican compression coeval with an eastward dipping intra-oceanic subduction, as previously proposed by Bouchachi (1993). This also corroborates the interpretation of recent magneto-gravimetric and magnetotelluric data beneath the central-western Hoggar (Brahimi et al., 2018; Deramchi et al., 2020), which have substantiated 
the presence of a major N-S anomaly interpreted as associated with a major suture zone located between the Silet and In-Tedeini domains, with a fossil east-dipping slab (Deramchi et al., 2020). The suture inferred from these data is located eastward of the NNW-SSE alignment of the presently studied In-Tedeini serpentinite outcrops. Hence, these mantle serpentinites are well-positioned to represent remnants of a mantle wedge exhumed in a NNW-SSE oriented suture zone. In this model, the suture connects the western Hoggar domains, which characterize a passive margin, with the central Hoggar (i.e., LATEA block; Fig., 1c), an active margin during the Panafrican collisional orogeny. This tectonic system would have closed part of the Goiás-Pharusian oceanic lithosphere located between these Archeo-Paleoproterozoic blocks (Meriem et al., 2004; Bendaoud et al., 2008; Bosch et al., 2016) through an east-dipping subduction.

Integrating $\mathrm{U}-\mathrm{Pb}$ ages obtained on the only two zircons recovered from a chloritite dike in North In-Tedeini serpentinites (Figs. 3d, 7g and 14) require caution in the interpretation due to low statistical data. Nevertheless, these new dating (770 \pm 5 and $631 \pm 10 \mathrm{Ma}$ ) coincide with the Panafrican geodynamic events of this region. Indeed, it agrees with the built-up stages of magmatic arcs recorded at the east of the suture zone, from $742 \mathrm{Ma}$ intra-oceanic affinity in Silet to 650-638 Ma active margin affinity in west of LATEA block (i.e., Aouilene; Fig. 1c), (Bouchachi, 1993; Bertrand, 2001; Bechiri-Benmerzoug, 2012). This supports our suggested east-dipping subduction scenario and would imply the crystallization of arc melts at $770 \pm 5 \mathrm{Ma}$ in the mantle wedge, and thus, that the subduction process was operating at this time. The younger age (631 \pm $10 \mathrm{Ma}$ ) may be associated with the emplacement of the serpentinized mantle wedge within the crust. It coincides with the end of the Panafrican collision event and the beginning of the postcollisional period marked by transpressional tectonics in the Hoggar (see Lapique 1986; BechiriBenmerzoug et al. 2017, Liégeois 2019). However, the inferred metasomatic origin of the chloritite (\$ 5.1.1) lead to an alternative hypothesis; it may implies that the zircons co-precipitated with chlorite and may rather record metasomatic event dating. The presence of two different ages (770 and $630 \mathrm{Ma}$ ) would then suggests the precipitation of zircons at two metasomatic events that may corresponds to mantle wedge and exhumation stages. Similar interpretation was suggested for zircons within metasomatic chloritites, in serpentinites from the southern Brasiliano orogen (Arena et al., 2017; Hartmann et al., 2021).

Moreover, the ocean closure developed southward in the Panafrican-Brasiliano belt also implies eastern vergence of intra-oceanic subduction interpreted in the Kabye massif (i.e., Togo; 
Guillot et al., 2019), and allowed the exhumation of rare remnants of serpentinized mantle along the Araguaia hyper-extended margin, accreted on the Amazonian craton (Hodel et al., 2019).

Today, the Sumatra fault system in Indonesia, an active strike-slip shear zone parallel to the oblique east-dipping subduction (Bellier and Sebrier, 1995) may represent an analogue of the pre-collisional evolution in the scenario presented in this study. The characterization of the suture zone through the study of the In-Tedeini serpentinites provided new constraints to understand the Neoproterozoic Panafrican geodynamic evolution of the Hoggar (Fig. 19) and the building of the West Gondwana supercontinent. Together with the $4^{\circ} 50^{\prime} \mathrm{E}$ transcurrent shear zone, this suture zone, which deformation evolved to a sinistral transpression, might be one of the principal components of the Transbrasiliano-Kandi shear system in the north of the Panafrican-Brasiliano belt.

\section{Conclusion}

We have reported field, petro-geochemical, mineral chemistry and geochronological data characterizing the serpentinite bodies distributed within magmatic and sedimentary formations along the In-Tedeini domain. The following conclusions were reached:

- The In-Tedeini serpentinites derive from mantle wedge harzburgites, involved in a subduction environment.

- Their very low major and trace geochemical signature, along with the high Cr\# for low to intermediate $\mathrm{Mg} \#$ in their preserved $\mathrm{Cr}$-spinels, point to high degrees of melt depletion likely in a subduction zone context.

- Their variable enrichment and correlated LREE and HFSE contents between the North and South In-Tedeini serpentinites reflect a petrogenetic relationship protolith that experienced a polyphased magmatic history.

- These observations, associated to REE melting modelling approach, reveal that these serpentinites experienced intense dynamic melting processes, influenced by fluid influx and melt refertilization, which operate in an intra-oceanic subduction setting. A variable thermal evolution in the mantle wedge likely reflects the divergence in geochemical 
signatures of South In-Tedeini serpentinites, which has been particularly refertilized by the island arc basaltic melts, compared to the Northern unit.

- Later, these rocks were subjected to a static mantle wedge serpentinization process by FME-rich fluids deriving from both subducted slab and oceanic sediments followed by processes involving localized $\mathrm{Si}$-, carbonate- and iron-rich fluids.

- Field evidence supports that the talc-schist zone envelops and preserves the massive serpentinite bodies of In-Tedeini. These bands of talc-schists that probably favoured the exhumation of the mantle wedge, have recorded an eastward steeply dipping sinistral shear zone, in which a strong transpressive deformation accommodate the collision.

- Interpretation of the two zircon ages recovered from a metasomatic chloritite dike provide new hints on chronology of the Panafrican orogeny in the studied area. They may have recorded the subduction related arc melts $(770 \pm 5 \mathrm{Ma})$ and the emplacement $(631 \pm 10$ $\mathrm{Ma}$ ) of mantle wedge serpentinites within the crust; or they may rather record the hydrothermal events endured by In-Tedeini serpentinites during their geodynamic evolution.

- Combining our results with previous geophysical data, and occurrence of remnants of island arcs in the Silet domain eastward, and the continental platform deposit westward, we infer that the nowadays-location of In-Tedeini serpentinites between these formations constitute key markers of a Neoproterozoic suture zone between the LATEA block and western Hoggar domains as the result of an east dipping intra-oceanic subduction, transpressive and sinistral strike-slip tectonics. This suture zone outlines the presence of an accretionary wedge structure, which include the coexistence of remnants of mantle wedge, deformed magmatic arc and sedimentary lithology, metamorphosed under amphibolitefacies conditions.

- The In-Tedeini serpentinites preserve a comprehensive record of a unique window on the Neoproterozoic oceanic mantle evolution in the Hoggar and represent one of the major suture zones resulting from the West Gondwana assembly. 


\section{Data availability}

All data used in this paper are available in the Supplementary data 1 to 6 online at Precambrian Research. These data include tables and map of the most important areas described in this article. Additional information may be requested from the corresponding author S.Ouadahi (ssoniaouadahi@gmail.com).

\section{CRediT authorship contribution statement}

Sonia Ouadahi: Conceptualization, Investigation, Methodology, Formal analysis, Writing original draft, Visualization. Abderrahmane Bendaoud: Conceptualization, Supervision, Investigation, Validation, Writing - review \& editing, Funding acquisition. Jean-Louis Bodinier: Supervision, Validation, Writing - review \& editing, Funding acquisition. Jean-Marie Dautria: Supervision, Investigation, Formal analysis, Writing - review \& editing. Alain Vauchez: Supervision, Writing - review \& editing. El-Hocine Fettous: Methodology, Investigation, Validation, Writing - review \& editing. Olivier Alard: Formal analysis, Writing - review \& editing.

\section{Declaration of Competing Interest}

The authors declare that they have no known competing financial interests or personal relationships that could have appeared to influence the work reported in this paper.

\section{Acknowledgements}

The authors gratefully thank F. Boudier, J-A. Padrón-Navarta, A. Chauvet, R. Caby, M. Godard, F. Roger and L. Mameri for insightful discussions. L. Mameri is also thanked for the linguistic help provided to this manuscript and for his comments on the figures. This work benefited from the assistance of T. Michel and D. Maurin for Raman spectroscopy analyses, F. Barou for EBSDSEM analyses, B. Boyer, R. Lafay and L. Blanchard for the electron microprobe analyses and, C. Martin and L. Causse for ICP-MS preparation and analyses. C. Nevado and D. Delmas are acknowledged for the preparation of high quality polished thin-sections. We also thank M. 
Guemmama, B. Brahmi and the cooker-drivers, as well as the Tamanrasset-CRAAG for their valuable support during the field campaigns. C.E. Ganade, two anonymous reviewers and editors (W. Teixeira and M. Babinsky) are gratefully acknowledged for their significant contributions that improved the quality of the paper. This paper is part of S. Ouadahi's $\mathrm{PhD}$ thesis.

\section{Funding sources}

This work has been funded by the FP7 IRSES-MEDYNA project (Maghreb-EU Research Staff Exchange on GeoDYnamics, Geohazards, and Applied Geology in northwest Africa, Work Package \#3: Deep structures and mantle processes): Marie Curie Action funded under Grant agreement PIRSES-GA- 2013-612572; the SO's PhD research grant of the Algerian ministry of Higher Education and Scientific Research; the Post-Graduation grant of the Faculty of Earth Sciences, USTHB, Algeria and the financial support via the PRFU E04N01UN160420220007: Cartographie, Géochimie, minéralogie et géochronologie des formations à minéralisations à PGE (Cr-Ni-Co), Nb-Ta et manganèse du Hoggar.

\section{Appendix A}

\section{Supplementary data}

Supplementary data to this article can be found in the online version, at https://doi.org/10.1016/j.precamres.2021.106505. 


\section{References}

Abed, H., 1983. Paléosuture à caractères ophiolitiques du Protérozoïque supérieur dans la région de Silet, Hoggar occidental (Algérie) (Doctoral dissertation).

Ahmed, A.H., Arai, S., Abdel-Aziz, Y.M. and Rahimi, A., 2005. Spinel composition as a petrogenetic indicator of the mantle section in the Neoproterozoic Bou Azzer ophiolite, Anti-Atlas, Morocco. Precambrian Research, 138(3-4), pp.225-234.

Aït Hamou, F. \& Dautria, J.-M., 1994. Le magmatisme cénozoïque du Hoggar : une synthèse des données disponibles. Mise au point sur l'hypothèse d'un point chaud. Bulletin du Service Géologique de l'Algérie, 5(1), pp.49-68.

Alt, J.C. and Shanks III, W.C., 2006. Stable isotope compositions of serpentinite seamounts in the Mariana forearc: serpentinization processes, fluid sources and sulfur metasomatism. Earth and Planetary Science Letters, 242(3-4), pp.272-285.

Alt, J.C., Schwarzenbach, E.M., Früh-Green, G.L., Shanks III, W.C., Bernasconi, S.M., Garrido, C.J., Crispini, L., Gaggero, L., Padrón-Navarta, J.A. and Marchesi, C., 2013. The role of serpentinites in cycling of carbon and sulfur: seafloor serpentinization and subduction metamorphism. Lithos, 178, pp.40-54.

Andreani, M., Escartin, J., Delacour, A., Ildefonse, B., Godard, M., Dyment, J., Fallick, A.E. and Fouquet, Y., 2014. Tectonic structure, lithology, and hydrothermal signature of the Rainbow massif (Mid-Atlantic Ridge $36^{\circ} 14^{\prime}$ N). Geochemistry, Geophysics, Geosystems, 15(9), pp.35433571 .

Andreani, Muriel, 2003. Les microstructures de de'formation des serpentines et la partition sismique-asismique: Exemple de la Californie, Ph.D. thesis, Univ. Joseph Fourier, Grenoble1, Grenoble, France.

Arai, S. and Ishimaru, S., 2008. Insights into petrological characteristics of the lithosphere of mantle wedge beneath arcs through peridotite xenoliths: a review. Journal of Petrology, 49(4), pp.665-695.

Arai, S., 1994. Characterization of spinel peridotites by olivine-spinel compositional relationships: review and interpretation. Chemical geology, 113(3-4), pp.191-204.

Arena, K.R., Hartmann, L.A. and Lana, C., 2017. Tonian emplacement of ophiolites in the southern Brasiliano Orogen delimited by $\mathrm{U}-\mathrm{Pb}-\mathrm{Hf}$ isotopes of zircon from metasomatites. Gondwana Research, 49, pp.296-332. http://dx.doi.org/10.1016/j.gr.2017.05.018 
Arthaud, M.H., Caby, R., Fuck, R.A., Dantas, E.L. and Parente, C.V., 2008. Geology of the northern Borborema Province, NE Brazil and its correlation with Nigeria, NW Africa. Geological Society, London, Special Publications, 294(1), pp.49-67.

Augé, T., Joubert, M. and Bailly, L., 2012. Typology of mafic-ultramafic complexes in Hoggar, Algeria: Implications for PGE, chromite and base-metal sulphide mineralisation. Journal of African Earth Sciences, 63, pp.32-47.

Auzende, A.L., Daniel, I., Reynard, B., Lemaire, C. and Guyot, F., 2004. High-pressure behaviour of serpentine minerals: a Raman spectroscopic study. Physics and Chemistry of Minerals, 31(5), pp.269-277.

Bach, W., Garrido, C.J., Paulick, H., Harvey, J. and Rosner, M., 2004. Seawater-peridotite interactions: First insights from ODP Leg 209, MAR 15 N. Geochemistry, Geophysics, Geosystems, 5(9).

Barrat, J.A., Zanda, B., Moynier, F., Bollinger, C., Liorzou, C. and Bayon, G., 2012. Geochemistry of CI chondrites: Major and trace elements, and $\mathrm{Cu}$ and $\mathrm{Zn}$ isotopes. Geochimica et Cosmochimica Acta, 83, pp.79-92.

Barth, M.G., Mason, P.R., Davies, G.R. and Drury, M.R., 2008. The Othris Ophiolite, Greece: A snapshot of subduction initiation at a mid-ocean ridge. Lithos, 100(1-4), pp.234-254.

Bau, M., 1991. Rare-earth element mobility during hydrothermal and metamorphic fluid-rock interaction and the significance of the oxidation state of europium. Chemical Geology, 93(3-4), pp.219-230.

Bechiri-Benmerzoug, F., 2012. Les granitoïdes de type TTG de la région de Silet, Hoggar, Algérie: Cartographie, pétrologie, géochimie isotopique et géochronologie. Editions universitaires europeennes, ISBN 13: 9783841784537.

Bechiri-Benmerzoug, F., Bonin, B., Bechiri, H., Khéloui, R., Talmat-Bouzeguela, S. and Bouzid, K., 2017. Hoggar geochronology: a historical review of published isotopic data. Arabian Journal of Geosciences, 10(16), pp.1-32.

Bellier, O. and Sebrier, M., 1995. Is the slip rate variation on the Great Sumatran Fault accommodated by fore-arc stretching?. Geophysical Research Letters, 22(15), pp.1969-1972.

Bendaoud, A., Ouzegane, K., Godard, G., Liégeois, J.P., Kienast, J.R., Bruguier, O. and Drareni, A., 2008. Geochronology and metamorphic PTX evolution of the Eburnean granulite-facies 
metapelites of Tidjenouine (Central Hoggar, Algeria): witness of the LATEA metacratonic evolution. Geological Society, London, Special Publications, 297(1), pp.111-146.

Bertrand, J.M.L. and Caby, R., 1978. Geodynamic evolution of the Pan-African orogenic belt: a new interpretation of the Hoggar shield (Algerian Sahara). Geologische Rundschau,67(2), pp.357-388.

Bertrand, J.M.L., 2001. Unpublished report, Office National de la Recherche Géologique et Minière ORGM.

Bizimis, M., Salters, V.J. and Bonatti, E., 2000. Trace and REE content of clinopyroxenes from supra-subduction zone peridotites. Implications for melting and enrichment processes in island arcs. Chemical Geology, 165(1-2), pp.67-85.

Black, R., Latouche, L., Liégeois, J.P., Caby, R. and Bertrand, J.M., 1994. Pan-African displaced terranes in the Tuareg shield (central Sahara). Geology, 22(7), pp.641-644.

Bodinier, J.L., Godard, M. 2014. 3.4 - Orogenic, Ophiolitic, and Abyssal Peridotites. Treatise on Geochemistry (Second Edition). In: Heinrich (Ed.), et al.. Elsevier Science Ltd., pp. 103-167. https://doi.org/10.1016/B978-0-08-095975-7.00204-7.

Bogolepov, V.G., 1970. Problem of serpentinization of ultrabasic rocks. International Geology Review, 12(4), pp.421-432.

Bosch, D., Bruguier, O., Caby, R., Buscail, F. and Hammor, D., 2016. Orogenic development of the Adrar des Iforas (Tuareg Shield, NE Mali): New geochemical and geochronological data and geodynamic implications. Journal of geodynamics, 96, pp.104-130.

Boschi, C., Bonatti, E., Ligi, M., Brunelli, D., Cipriani, A., Dallai, L., D'Orazio, M., Frueh-Green, G.L., Tonarini, S., Barnes, J.D. and Bedini, R.M., 2013. Serpentinization of mantle peridotites along an uplifted lithospheric section, Mid Atlantic Ridge at 11 N. Lithos, 178, pp.3-23.

Boskabadi, A., 2020. Carbonate Alteration of Ophiolitic Rocks: Sources of Fluids, Conditions of Alteration, and Element Mobility. The University of Texas at Dallas. https://hdl.handle.net/10735.1/8890.

Bouchachi, M.A., 1993. Géologie de la région Timgaouine-Abankor (Hoggar, Algérie). Caractérisation géochimique du paléomagmatisme du bassin d'Abankor et implications géodynamiques. University of Paris 6. https://www.theses.fr/1993PA066033 
Boukhalfa, L., 1987. Diversité et signification géodynamique des complexes ultrabasiques/basiques d'âge protérozoïque supérieur du rameau oriental pharusien de la chaîne panafricaine (Hoggar, Algérie). University of Nancy 1. https://www.theses.fr/1987NAN10040 Boukhalfa, L., 2002. Les formations volcano-sédimentaires néoprotérozoïques de la branche orientale de la chaîne pharusienne (Hoggar occidental, Algérie): lithologie et géochimie. Mémoires du Service géologique de l'Algérie, (11), pp.9-31.

Brahimi, S., Liégeois, J.P., Ghienne, J.F., Munschy, M. and Bourmatte, A., 2018. The Tuareg shield terranes revisited and extended towards the northern Gondwana margin: Magnetic and gravimetric constraints. Earth-Science Reviews, 185, pp.572-599.

Brovarone, A.V., Sverjensky, D.A., Piccoli, F., Ressico, F., Giovannelli, D. and Daniel, I., 2020. Subduction hides high-pressure sources of energy that may feed the deep subsurface biosphere. Nature communications, 11(1), pp.1-11.

Brunelli, D., Paganelli, E. and Seyler, M., 2014. Percolation of enriched melts during incremental open-system melting in the spinel field: A REE approach to abyssal peridotites from the Southwest Indian Ridge. Geochimica et Cosmochimica Acta, 127, pp.190-203.

Bucher, K. and Grapes, R., 2011. Metamorphism of ultramafic rocks. In Petrogenesis of Metamorphic Rocks (pp. 191-224). Springer, Berlin, Heidelberg.

Caby, R., 1989. Precambrian terranes of Benin-Nigeria and northeast Brazil. Terranes in the Circum-Atlantic Paleozoic Orogens, 230, p.145.

Caby, R., 2003. Terrane assembly and geodynamic evolution of central-western Hoggar: a synthesis. Journal of African Earth Sciences, 37(3-4), pp.133-159.

Caby, R., Sial, A.N., Arthaud, M. and Vauchez, A., 1991. Crustal evolution and the Brasiliano orogeny in Northeast Brazil. In The west African orogens and circum-Atlantic correlatives (pp. 373-397). Springer, Berlin, Heidelberg.

Caby, R., Andreopoulos-Renaud, U., Gravelle, M., 1982. Cadre géologique et géochronologie $\mathrm{U} / \mathrm{Pb}$ sur zircon des batholites précoces dans le segment pan-africain du Hoggar central (Algérie). Bulletin de la Société Géologique de France, 24, pp. 677-684

Cannaò, E., Scambelluri, M., Agostini, S., Tonarini, S. and Godard, M., 2016. Linking serpentinite geochemistry with tectonic evolution at the subduction plate-interface: The Voltri Massif case study (Ligurian Western Alps, Italy). Geochimica et Cosmochimica Acta, 190, pp.115-133. 
Castaing, C., Feybesse, J.L., Thiéblemont, D., Triboulet, C. and Chevremont, P., 1994. Palaeogeographical reconstructions of the Pan-African/Brasiliano orogen: closure of an oceanic domain or intracontinental convergence between major blocks?. Precambrian Research, 69(1-4), pp.327-344.

Caxito, F.D.A., Santos, L.C.M.D.L., Ganade, C.E., Bendaoud, A., Fettous, E.H. and Bouyo, M.H., 2020a. Toward an integrated model of geological evolution for NE Brazil-NW Africa: The Borborema Province and its connections to the Trans-Saharan (Benino-Nigerian and Tuareg shields) and Central African orogens. Brazilian Journal of Geology, 50(2).

Chikhaoui, M., Dupuy, C.T. and Dostal, J., 1980. Geochemistry and petrogenesis of Late Proterozoic volcanic rocks from north-western Africa. Contributions to Mineralogy and Petrology, 73(4), pp.375-388.

Coleman, R.G. and Keith, T.E., 1971. A chemical study of serpentinization-Burro Mountain, California. Journal of Petrology, 12(2), pp.311-328.

Cordani, U.G., Pimentel, M.M., de Araújo, C.E.G. and Fuck, R.A., 2013b. THE SIGNIFICANCE OF THE TRANSBRASILIANO-KANDI TECTONIC CORRIDOR FOR THE AMALGAMATION OF WEST GONDWANA. Brazilian journal of Geology, 43(3), pp.583-597. Corfu, F., Hanchar, J.M., Hoskin, P.W. and Kinny, P., 2003. Atlas of zircon textures. Reviews in mineralogy and geochemistry, 53(1), pp.469-500.

Dada, S.S., 2008. Proterozoic evolution of the Nigeria-Boborema province. Geological Society, London, Special Publications, 294(1), pp.121-136.

Dautria, J.M. and Lesquer, A., 1989. An example of the relationship between rift and dome: recent geodynamic evolution of the Hoggar swell and of its nearby regions (Central Sahara, Southern Algeria and Eastern Niger). Tectonophysics, 163(1-2), pp.45-61.

de Brito Neves, B.B., Van Schmus, W.R. and Fetter, A., 2002. North-western Africa-North-eastern Brazil. Major tectonic links and correlation problems. Journal of African Earth Sciences, 34(3-4), pp.275-278.

De Hoog, J.C.M., Janák, M., Vrabec, M. and Froitzheim, N., 2009. Serpentinised peridotites from an ultrahigh-pressure terrane in the Pohorje Mts.(Eastern Alps, Slovenia): geochemical constraints on petrogenesis and tectonic setting. Lithos, 109(3-4), pp.209-222. 
De Wit, M.J., Stankiewicz, J. and Reeves, C., 2008. Restoring Pan-African-Brasiliano connections: more Gondwana control, less trans-Atlantic corruption. Geological Society, London, Special Publications, 294(1), pp.399-412.

Debret, B., 2013. Serpentinites, vecteurs des circulations fluides et des transferts chimiques de l'océanisation à la subduction: exemple dans les Alpes occidentales (Doctoral dissertation, Université Blaise Pascal-Clermont-Ferrand II).

Debret, B., Bouilhol, P., Pons, M.L. and Williams, H., 2018. Carbonate transfer during the onset of slab devolatilization: New insights from Fe and Zn stable isotopes. Journal of Petrology, 59(6), pp.1145-1166.

Debret, B., Reekie, C.D.J., Mattielli, N., Savov, I., Beunon, H., Ménez, B. and Williams, H.M., 2020. Redox transfer at subduction zones: insights from Fe isotopes in the Mariana forearc. Geochemical Perspectives Letters, 12, pp.46-51.

Deramchi, A., Bouzid, A., Bendaoud, A., Ritter, O., Hamoudi, M., Cruces-Zabala, J., Meqbel, N., Boukhalfa, Z., Boughchiche, S.S., Abtout, A. and Boukhlouf, W., 2020. Neoproterozoic amalgamation and Phanerozoic reactivation of Central/Western Hoggar (Southern Algeria, Tuareg Shield) lithosphere imaging using magnetotelluric data. Journal of Geodynamics, 139, p.101764.

Deschamps, F., Godard, M., Guillot, S. and Hattori, K., 2013. Geochemistry of subduction zone serpentinites: A review. Lithos, 178, pp.96-127.

Deschamps, F., Guillot, S., Godard, M., Chauvel, C., Andreani, M. and Hattori, K., 2010. In situ characterization of serpentinites from forearc mantle wedges: timing of serpentinization and behavior of fluid-mobile elements in subduction zones. Chemical Geology, 269(3-4), pp.262-277. Dick, H.J. and Bullen, T., 1984. Chromian spinel as a petrogenetic indicator in abyssal and alpinetype peridotites and spatially associated lavas. Contributions to mineralogy and petrology, 86(1), pp.54-76.

Dilek, Y. and Furnes, H., 2011. Ophiolite genesis and global tectonics: Geochemical and tectonic fingerprinting of ancient oceanic lithosphere. Bulletin, 123(3-4), pp.387-411.

Dilek, Y. and Furnes, H., 2014. Ophiolites and their origins. Elements, 10(2), pp.93-100. DOI:10.2113/gselements.10.2.93

Dos Santos, T.J.S., Fetter, A.H. and Neto, J.N., 2008. Comparisons between the northwestern Borborema Province, NE Brazil, and the southwestern Pharusian Dahomey Belt, SW Central Africa. Geological Society, London, Special Publications, 294(1), pp.101-120. 
Droop, G.T.R., 1987. A general equation for estimating Fe 3+ concentrations in ferromagnesian silicates and oxides from microprobe analyses, using stoichiometric criteria. Mineralogical magazine, 51(361), pp.431-435.

Dubińska, E., Bylina, P., Kozłowski, A., Dörr, W., Nejbert, K., Schastok, J. and Kulicki, C., 2004. $\mathrm{U}-\mathrm{Pb}$ dating of serpentinization: hydrothermal zircon from a metasomatic rodingite shell (Sudetic ophiolite, SW Poland). Chemical Geology,203(3-4), pp.183-203. https://doi.org/10.1016/j.chemgeo.2003.10.005

Dupont, P.L., Lapierre, H., Gravelle, M. and Bertrand, J.M., 1987. Caractérisation du magmatisme Protérozoïque supérieur en Afrique de l'ouest et implications géodynamiques: des rifts intracratoniques au Panafricain?. Canadian Journal of Earth Sciences, 24(1), pp.96109. https://doi.org/10.1139/e87-008

EILER, J.M., Crawford, A., Elliott, T.I.M., Farley, K.A., Valley, J.W. and Stolper, E.M., 2000. Oxygen isotope geochemistry of oceanic-arc lavas. Journal of Petrology, 41(2), pp.229-256.

Eiler, J.M., Schiano, P., Valley, J.W., Kita, N.T. and Stolper, E.M., 2007. Oxygen-isotope and trace element constraints on the origins of silica-rich melts in the subarc mantle. Geochemistry, Geophysics, Geosystems, 8(9).

El Dien, H.G., Hamdy, M., El-Ela, A.S.A., Abu-Alam, T., Hassan, A., Kil, Y., Mizukami, T. and Soda, Y., 2016. Neoproterozoic serpentinites from the Eastern Desert of Egypt: insights into Neoproterozoic mantle geodynamics and processes beneath the Arabian-Nubian Shield. Precambrian Research, 286, pp.213-233.

Elhlou, S., Belousova, E., Griffin, W.L., Pearson, N.J. and O? Reilly, S.Y., 2006. Trace element and isotopic composition of GJ-red zircon standard by laser ablation. Geochimica et Cosmochimica Acta, 70(18), pp.158-158.

Escartin, J., Andreani, M., Hirth, G. and Evans, B., 2008a. Relationships between the microstruct ural evolution and the rheology of talc at elevated pressures and temperatures. Earth and Planeta ry Science Letters, 268(3-4), pp.463-475. http://dx.doi.org/10.1016/j.eps1.2008.02.004

Escuder-Viruete, J., Pérez-Estaún, A., Booth-Rea, G. and Valverde-Vaquero, P., 2011. Tectonometamorphic evolution of the Samaná complex, northern Hispaniola: Implications for the burial and exhumation of high-pressure rocks in a collisional accretionary wedge. Lithos, 125(12), pp.190-210. 
Evans, B.W., 2004. The serpentinite multisystem revisited: chrysotile is metastable. International Geology Review, 46(6), pp.479-506.

Evans, B.W., Hattori, K. and Baronnet, A., 2013. Serpentinite: what, why, where?. Elements, 9(2), pp.99-106.

Fossen, H. and Tikoff, B., 1998. Extended models of transpression and transtension, and application to tectonic settings. Geological Society, London, Special Publications, 135(1), pp.1533.

Franz, L. and Wirth, R., 2000. Spinel inclusions in olivine of peridotite xenoliths from TUBAF seamount (Bismarck Archipelago/Papua New Guinea): evidence for the thermal and tectonic evolution of the oceanic lithosphere. Contributions to Mineralogy and Petrology, 140(3), pp.283295.

Furnes, H., De Wit, M. and Dilek, Y., 2014. Four billion years of ophiolites reveal secular trends in oceanic crust formation. Geoscience Frontiers, 5(4), pp.571-603.

Furnes, H., Dilek, Y.D. and De Wit, M., 2015. Precambrian greenstone sequences represent different ophiolite types. Gondwana research, 27(2), pp.649-685.

Gain, S.E., Gréau, Y., Henry, H., Belousova, E., Dainis, I., Griffin, W.L. and O'reilly, S.Y., 2019.

Mud Tank Zircon: Long-term evaluation of a reference material for $\mathrm{U}-\mathrm{Pb}$ dating, Hf-isotope analysis and trace element analysis. Geostandards and Geoanalytical Research, 43(3), pp.339354.

Ganade de Araujo, C.E., Cordani, U.G., Agbossoumounde, Y., Caby, R., Basei, M.A., Weinberg, R.F. and Sato, K., 2016. Tightening-up NE Brazil and NW Africa connections: New U-Pb/Lu-Hf zircon data of a complete plate tectonic cycle in the Dahomey belt of the West Gondwana Orogen in Togo and Benin. Precambrian Research, 276, pp.24-42.

Ganade de Araujo, C.E., Cordani, U.G., Weinberg, R.F., Basei, M.A., Armstrong, R. and Sato, K., 2014a. Tracing Neoproterozoic subduction in the Borborema Province (NE-Brazil): Clues from U-Pb geochronology and Sr-Nd-Hf-O isotopes on granitoids and migmatites. Lithos, 202, pp.167189.

Ganade de Araujo, C.E., Rubatto, D., Hermann, J., Cordani, U.G., Caby, R. and Basei, M.A., 2014b. Ediacaran 2,500-km-long synchronous deep continental subduction in the West Gondwana Orogen. Nature communications, 5(1), pp.1-8. 
Godard, M., Jousselin, D. and Bodinier, J.L., 2000. Relationships between geochemistry and structure beneath a palaeo-spreading centre: a study of the mantle section in the Oman ophiolite. Earth and Planetary Science Letters, 180(1-2), pp.133-148.

Godard, M., Lagabrielle, Y., Alard, O. and Harvey, J., 2008. Geochemistry of the highly depleted peridotites drilled at ODP Sites 1272 and 1274 (Fifteen-Twenty Fracture Zone, Mid-Atlantic Ridge): Implications for mantle dynamics beneath a slow spreading ridge. Earth and Planetary Science Letters, 267(3-4), pp.410-425.

Grieco, G., Ferrario, A., von Quadt, A., Koeppel, V. and Mathez, E.A., 2001. The zircon-bearing chromitites of the phlogopite peridotite of Finero (Ivrea Zone, Southern Alps): evidence and geochronology of a metasomatized mantle slab. Journal of Petrology, 42(1), pp.89-101. https://doi.org/10.1093/petrology/42.1.89

Griffin, W.L., Pearson, N.J., Belousova, E., Jackson, S.V., Van Achterbergh, E., O'Reilly, S.Y. and Shee, S.R., 2000. The Hf isotope composition of cratonic mantle: LAM-MC-ICPMS analysis of zircon megacrysts in kimberlites. Geochimica et cosmochimica acta, 64(1), pp.133-147. https://doi.org/10.1016/S0016-7037(99)00343-9.

Griffin, W.L., Powell, W.J., Pearson, N.J., O'Reilly, S.Y., 2008. GLITTER: data reduction software for laser ablation ICP-MSP. Sylvester (Ed.), Laser Ablation-ICP-MS in the Earth Sciences. Mineralogical Association of Canada Short Course Series 40, 204-207.

Groppo, C., Rinaudo, C., Cairo, S., Gastaldi, D. and Compagnoni, R., 2006. Micro-Raman spectroscopy for a quick and reliable identification of serpentine minerals from ultramafics. European Journal of Mineralogy, 18(3), pp.319-329.

Guillot, S. and Hattori, K., 2013. Serpentinites: essential roles in geodynamics, arc volcanism, sustainable development, and the origin of life. Elements, 9(2), pp.95-98.

Guillot, S., Agbossoumondé, Y., Bascou, J., Berger, J., Duclaux, G., Hilairet, N., Ménot, R.P. and Schwartz, S., 2019. Transition from subduction to collision recorded in the Pan-African arc complexes (Mali to Ghana). Precambrian Research,320, pp.261-280. https://doi.org/10.1016/j.precamres.2018.11.007

Guillot, S., Hattori, K., Agard, P., Schwartz, S. and Vidal, O., 2009. Exhumation processes in oceanic and continental subduction contexts: a review. Subduction zone geodynamics, pp.175-205. Guillot, S., Schwartz, S., Reynard, B., Agard, P. and Prigent, C., 2015. Tectonic significance of serpentinites. Tectonophysics, 646, pp.1-19. 
Hartmann, L.A., Massuda, A.J., Cerva-Alves, T., Lana, C., Leandro, C.G. and Savian, J.F., 2021. Aeromagnetometry and aerogammaspectrometry integrated with U-Pb zircon geochronology of northern Bossoroca ophiolite, Brasiliano Orogen. Anais da Academia Brasileira de Ciências, 93. https://doi.org/10.1590/0001-3765202120190791

Harvey, J., Savov, I.P., Agostini, S., Cliff, R.A. and Walshaw, R., 2014. Si-metasomatism in serpentinized peridotite: the effects of talc-alteration on strontium and boron isotopes in abyssal serpentinites from Hole 1268a, ODP Leg 209. Geochimica et Cosmochimica Acta, 126, pp.30-48. Hattori, K.H. and Guillot, S., 2007. Geochemical character of serpentinites associated with highto ultrahigh-pressure metamorphic rocks in the Alps, Cuba, and the Himalayas: Recycling of elements in subduction zones. Geochemistry, Geophysics, Geosystems, 8(9).

Hébert, R., Gueddari, K., Lafleche, M.R., Beslier, M.O. and Gardien, V., 2001. Petrology and geochemistry of exhumed peridotites and gabbros at non-volcanic margins: ODP Leg 173 West Iberia ocena-continent transition zone. Geological Society, London, Special Publications, 187(1), pp.161-189.

Hellebrand, E., Snow, J.E., Dick, H.J. and Hofmann, A.W., 2001. Coupled major and trace elements as indicators of the extent of melting in mid-ocean-ridge peridotites. Nature, 410(6829), pp.677-681.

Hellebrand, E., SNOW, J.E., Hoppe, P. and HOFMANN, A.W., 2002b. Garnet-field melting and late-stage refertilization in 'residual'abyssal peridotites from the Central Indian Ridge. Journal of Petrology, 43(12), pp.2305-2338.

Hodel, F., Macouin, M., Triantafyllou, A., Carlut, J., Berger, J., Rousse, S., Ennih, N. and Trindade, R.I.F., 2017. Unusual massive magnetite veins and highly altered Cr-spinels as relics of a Cl-rich acidic hydrothermal event in Neoproterozoic serpentinites (Bou Azzer ophiolite, AntiAtlas, Morocco). Precambrian Research, 300, pp.151-167.

Hodel, F., Macouin, M., Trindade, R.I.F., Triantafyllou, A., Ganne, J., Chavagnac, V., Berger, J., Rospabé, M., Destrigneville, C., Carlut, J. and Ennih, N., 2018. Fossil black smoker yields oxygen isotopic composition of Neoproterozoic seawater. Nature communications, 9(1), pp.1-7.

Hodel, F., Triantafyllou, A., Berger, J., Macouin, M., Baele, J.M., Mattielli, N., Monnier, C., Trindade, R.I.F., Ducea, M.N., Chatir, A. and Ennih, N., 2020. The Moroccan Anti-Atlas ophiolites: Timing and melting processes in an intra-oceanic arc-back-arc environment. Gondwana Research, 86, pp.182-202. 
Hodel, F., Trindade, R.I.F., Macouin, M., Meira, V.T., Dantas, E.L., Paixão, M.A.P., Rospabé, M., Castro, M.P., Queiroga, G.N., Alkmim, A.R. and Lana, C.C., 2019. A Neoproterozoic hyperextended margin associated with Rodinia's demise and Gondwana's build-up: The Araguaia Belt, central Brazil. Gondwana Research, 66, pp.43-62. doi: 10.1016/j.gr.2018.08.010

Hyndman, R.D. and Peacock, S.M., 2003. Serpentinization of the forearc mantle. Earth and Planetary Science Letters, 212(3-4), pp.417-432.

Ionov, D.A., Savoyant, L. and Dupuy, C., 1992. Application of the ICP-MS technique to trace element analysis of peridotites and their minerals. Geostandards Newsletter, 16(2), pp.311-315.

Ishii, T., Robinson, P.T., Maekawa, H., Fiske, R., 1992. Petrological studies of peridotites from diapiric serpentinite seamounts in the Izu-Ogasawara-Mariana forearc, Leg 125. Proceedings of the Ocean Drilling Program, Scientific Results 125, 445-485.

Iyer, K., Austrheim, H., John, T. and Jamtveit, B., 2008. Serpentinization of the oceanic lithosphere and some geochemical consequences: constraints from the Leka Ophiolite Complex, Norway. Chemical Geology, 249(1-2), pp.66-90.

Jackson, S.E., Pearson, N.J., Griffin, W.L. and Belousova, E.A., 2004. The application of laser ablation-inductively coupled plasma-mass spectrometry to in situ U-Pb zircon geochronology. Chemical geology, 211(1-2), pp.47-69.

Janecky, D.R. and Seyfried Jr, W.E., 1986. Hydrothermal serpentinization of peridotite within the oceanic crust: Experimental investigations of mineralogy and major element chemistry. Geochimica et Cosmochimica Acta, 50(7), pp.1357-1378.

Kaczmarek, M.A., Müntener, O. and Rubatto, D., 2008. Trace element chemistry and U-Pb dating of zircons from oceanic gabbros and their relationship with whole rock composition (Lanzo, Italian Alps). Contributions to Mineralogy and Petrology, 155(3), pp.295-312. https://doi.org/10.1007/s00410-007-0243-3

Kelemen, P.B., Hanghøj, K. and Greene, A.R., 2003. One view of the geochemistry of subductionrelated magmatic arcs, with an emphasis on primitive andesite and lower crust. Treatise on geochemistry, 3, p.659.

Kodolányi, J., Pettke, T., Spandler, C., Kamber, B.S. and Gméling, K., 2012. Geochemistry of ocean floor and fore-arc serpentinites: constraints on the ultramafic input to subduction zones. Journal of Petrology, 53(2), pp.235-270. 
Kogiso, T., Tatsumi, Y. and Nakano, S., 1997. Trace element transport during dehydration processes in the subducted oceanic crust: 1. Experiments and implications for the origin of ocean island basalts. Earth and Planetary Science Letters, 148(1-2), pp.193-205.

Komor, S.C., Elthon, D. and Casey, J.F., 1985. Mineralogic variation in a layered ultramafic cumulate sequence at the North Arm Mountain Massif, Bay of Islands Ophiolite, Newfoundland. Journal of Geophysical Research: Solid Earth, 90(B9), pp.7705-7736.

Kröner, A. and Cordani, U., 2003. African, southern Indian and South American cratons were not part of the Rodinia supercontinent: evidence from field relationships and geochronology. Tectonophysics, 375(1-4), pp.325-352.

Kusky, T.M., Windley, B.F., Safonova, I., Wakita, K., Wakabayashi, J., Polat, A. and Santosh, M., 2013. Recognition of ocean plate stratigraphy in accretionary orogens through Earth history: A record of 3.8 billion years of sea floor spreading, subduction, and accretion. Gondwana Research, 24(2), pp.501-547.

Lafay, R., Deschamps, F., Schwartz, S., Guillot, S., Godard, M., Debret, B. and Nicollet, C., 2013. High-pressure serpentinites, a trap-and-release system controlled by metamorphic conditions: Example from the Piedmont zone of the western Alps. Chemical Geology, 343, pp.38-54.

Lafuente, B., Downs, R.T., Yang, H. and Stone, N., 2016. The power of databases: the RRUFF project. In Highlights in mineralogical crystallography (pp. 1-29). Walter de Gruyter GmbH. https://rruff.info/

Lagabrielle, Y., Karpoff, A.M., Cotten, J., 1992. 18. Mineralogical and geochemical analyses of sedimentary serpentinites from conical seamount (Hole 778A): implications for the evolution of serpentine seamounts. Proceedings of the Ocean Drilling Program, Scientific Results 125, 325342.

Lapique, F., Bertrand, J.M. and Meriem, D., 1986. A major Pan-African crustal decoupling zone in the Timgaouine area (Western Hoggar, Algeria). Journal of African Earth Sciences (1983), 5(6), pp.617-625.

Le Roux, V., Bodinier, J.L., Tommasi, A., Alard, O., Dautria, J.M., Vauchez, A. and Riches, A.J.V., 2007. The Lherz spinel lherzolite: refertilized rather than pristine mantle. Earth and Planetary Science Letters, 259(3-4), pp.599-612. 
Lenoir, X., Garrido, C.J., Bodinier, J.L., Dautria, J.M. and Gervilla, F., 2001. The recrystallization front of the Ronda peridotite: evidence for melting and thermal erosion of subcontinental lithospheric mantle beneath the Alboran Basin. Journal of Petrology, 42(1), pp.141-158.

Lesquer, A., Bourmatte, A. and Dautria, J.M., 1988. Deep structure of the Hoggar domal uplift (central Sahara, south Algeria) from gravity, thermal and petrological data. Tectonophysics, 152(1-2), pp.71-87.

Li, Y.H., Schoonmaker, J.E., 2003. 7.01 Chemical composition and mineralogy of marine sediments. In: Mackenzie (Ed.), Treatise on Geochemistry, 7. Elsevier Science Ltd., pp. 1-35. https://doi.org/10.1016/B0-08-043751-6/07088-2.

Liégeois, J.P., 2019. A new synthetic geological map of the Tuareg Shield: an overview of its global structure and geological evolution. The Geology of the Arab World-An Overview, pp.83107.

Liégeois, J.P., Latouche, L., Boughrara, M., Navez, J. and Guiraud, M., 2003. The LATEA metacraton (Central Hoggar, Tuareg shield, Algeria): behaviour of an old passive margin during the Pan-African orogeny. Journal of African Earth Sciences, 37(3-4), pp.161-190.

Malvoisin, B., 2015. Mass transfer in the oceanic lithosphere: serpentinization is not isochemical. Earth and Planetary Science Letters, 430, pp.75-85.

McDonough, W.F. and Sun, S.S., 1995. The composition of the Earth. Chemical geology, 120(34), pp.223-253.

McDonough, W.F., Frey, F.A., 1989. Geochemistry and mineralogy of rare earth elements. Rev. Mineral, 21. The mineralogical society of America, pp. 99-145.

Meriem, D.E., Boukhalfa, L., Bellal, M., Boufassa, A.E., 2004. Carte Géologique du Massif du Hoggar au 1/1.000.000. Office National de la Recherche Géologique et Minière ORGM.

Merlet, C., 1994. An accurate computer correction program for quantitative electron probe microanalysis. Microchimica Acta, 114(1), pp.363-376.

Mével, C., 2003. Serpentinization of abyssal peridotites at mid-ocean ridges. Comptes Rendus Geoscience, 335(10-11), pp.825-852.

Miyashiro, A., Shido, F. and Ewing, M., 1969. Composition and origin of serpentinites from the Mid-Atlantic Ridge near 24 and 30 north latitude. Contributions to Mineralogy and Petrology, 23(2), pp.117-127. 
Morishita, T., Hara, K., Nakamura, K., Sawaguchi, T., Tamura, A., Arai, S., Okino, K., Takai, K. and Kumagai, H., 2009. Igneous, alteration and exhumation processes recorded in abyssal peridotites and related fault rocks from an oceanic core complex along the Central Indian Ridge. Journal of Petrology, 50(7), pp.1299-1325. https://doi.org/10.1093/petrology/egp025

Mothersole, F.E., Evans, K. and Frost, B.R., 2017. Abyssal and hydrated mantle wedge serpentinised peridotites: a comparison of the $15^{\circ} 20^{\prime} \mathrm{N}$ fracture zone and New Caledonia serpentinites. Contributions to Mineralogy and Petrology, 172(8), pp.1-25.)

Navon, O. and Stolper, E., 1987. Geochemical consequences of melt percolation: the upper mantle as a chromatographic column. The Journal of Geology, 95(3), pp.285-307.

Nicolas, A. and Dupuy, C., 1984. Origin of ophiolitic and oceanic lherzolites. Tectonophysics, 110(3-4), pp.177-187.

Niu, Y., 2004. Bulk-rock major and trace element compositions of abyssal peridotites: implications for mantle melting, melt extraction and post-melting processes beneath mid-ocean ridges. Journal of Petrology, 45(12), pp.2423-2458.

O'Hanley, D.S., 1996. Serpentinites: records of tectonic and petrological history. Oxford University Press on Demand.

Oliveira, E.P., Toteu, S.F., Araújo, M.N.C., Carvalho, M.J., Nascimento, R.S., Bueno, J.F., McNaughton, N. and Basilici, G., 2006. Geologic correlation between the Neoproterozoic Sergipano belt (NE Brazil) and the Yaoundé belt (Cameroon, Africa). Journal of African Earth Sciences, 44(4-5), pp.470-478.

Ozawa, K. and Shimizu, N., 1995. Open-system melting in the upper mantle: Constraints from the Hayachine-Miyamori ophiolite, northeastern Japan. Journal of Geophysical Research: Solid Earth, 100(B11), pp.22315-22335.

Padrón-Navarta, J.A., Sánchez-Vizcaíno, V.L., Hermann, J., Connolly, J.A., Garrido, C.J., Gómez-Pugnaire, M.T. and Marchesi, C., 2013. Tschermak's substitution in antigorite and consequences for phase relations and water liberation in high-grade serpentinites. Lithos, 178, pp.186-196.

Palandri, J.L. and Reed, M.H., 2004. Geochemical models of metasomatism in ultramafic systems: serpentinization, rodingitization, and sea floor carbonate chimney precipitation. Geochimica et Cosmochimica Acta, 68(5), pp.1115-1133. 
Parkinson, I.J. and Pearce, J.A., 1998. Peridotites from the Izu-Bonin-Mariana forearc (ODP Leg 125): evidence for mantle melting and melt-mantle interaction in a supra-subduction zone setting. Journal of Petrology, 39(9), pp.1577-1618.

Paulick, H., Bach, W., Godard, M., De Hoog, J.C.M., Suhr, G. and Harvey, J., 2006. Geochemistry of abyssal peridotites (Mid-Atlantic Ridge, $15^{\circ} 20^{\prime} \mathrm{N}$, ODP Leg 209): implications for fluid/rock interaction in slow spreading environments. Chemical geology, 234(3-4), pp.179-210.

Pearce, J.A. and Parkinson, I.J., 1993. Trace element models for mantle melting: application to volcanic arc petrogenesis. Geological Society, London, Special Publications, 76(1), pp.373-403.

Pearce, J.A., Baker, P.E., Harvey, P.K. and Luff, I.W., 1995. Geochemical evidence for subduction fluxes, mantle melting and fractional crystallization beneath the South Sandwich island arc. Journal of Petrology, 36(4), pp.1073-1109.

Peters, D., Bretscher, A., John, T., Scambelluri, M. and Pettke, T., 2017. Fluid-mobile elements in serpentinites: Constraints on serpentinisation environments and element cycling in subduction zones. Chemical geology, 466, pp.654-666.

Petriglieri, J.R., Salvioli-Mariani, E., Mantovani, L., Tribaudino, M., Lottici, P.P., LaporteMagoni, C. and Bersani, D., 2015. Micro-Raman mapping of the polymorphs of serpentine. Journal of Raman Spectroscopy, 46(10), pp.953-958.

Plank, T. and Langmuir, C.H., 1998. The chemical composition of subducting sediment and its consequences for the crust and mantle. Chemical geology, 145(3-4), pp.325-394.

Rinaudo, C., Gastaldi, D. and Belluso, E., 2003. Characterization of chrysotile, antigorite and lizardite by FT-Raman spectroscopy. The Canadian Mineralogist, 41(4), pp.883-890.

Rougier, S., Missenard, Y., Gautheron, C., Barbarand, J., Zeyen, H., Pinna, R., Liégeois, J.P., Bonin, B., Ouabadi, A., Derder, M.E.M. and de Lamotte, D.F., 2013. Eocene exhumation of the Tuareg Shield (Sahara Desert, Africa). Geology, 41(5), pp.615-618.

Rouméjon, S., Cannat, M., Agrinier, P., Godard, M. and Andreani, M., 2015. Serpentinization and fluid pathways in tectonically exhumed peridotites from the Southwest Indian Ridge (62-65 E). Journal of Petrology, 56(4), pp.703-734.

Saha, A., Santosh, M., Ganguly, S., Manikyamba, C., Ray, J. and Dutta, J., 2018. Geochemical cycling during subduction initiation: Evidence from serpentinized mantle wedge peridotite in the south Andaman ophiolite suite. Geoscience Frontiers, 9(6), pp.1755-1775. 
Savov, I.P., Ryan, J.G., D'Antonio, M. and Fryer, P., 2007. Shallow slab fluid release across and along the Mariana arc-basin system: Insights from geochemistry of serpentinized peridotites from the Mariana fore arc. Journal of Geophysical Research: Solid Earth, 112(B9).

Savov, I.P., Ryan, J.G., D'Antonio, M., Kelley, K. and Mattie, P., 2005a. Geochemistry of serpentinized peridotites from the Mariana Forearc Conical Seamount, ODP Leg 125: Implications for the elemental recycling at subduction zones. Geochemistry, Geophysics, Geosystems, 6(4).

Scambelluri, M., Cannaò, E. and Gilio, M., 2019. The water and fluid-mobile element cycles during serpentinite subduction. A review. European Journal of Mineralogy, 31(3), pp.405-428.

Schwartz, S., Guillot, S., Reynard, B., Lafay, R., Debret, B., Nicollet, C., Lanari, P. and Auzende, A.L., 2013. Pressure-temperature estimates of the lizardite/antigorite transition in high pressure serpentinites. Lithos, 178, pp.197-210.

Seifert, K. and Brunotte, D., 1996. Geochemistry of serpentinized mantle peridotite from Site 897 in the Iberia Abyssal Plain. In PROCEEDINGS-OCEAN DRILLING PROGRAM SCIENTIFIC RESULTS (pp. 413-424). NATIONAL SCIENCE FOUNDATION.

Snow, J.E. and Dick, H.J., 1995. Pervasive magnesium loss by marine weathering of peridotite. Geochimica et Cosmochimica Acta, 59(20), pp.4219-4235.

Stern, R.J., Reagan, M., Ishizuka, O., Ohara, Y. and Whattam, S., 2012. To understand subduction initiation, study forearc crust: To understand forearc crust, study ophiolites. Lithosphere, 4(6), pp.469-483.

Streckeisen, A., 1976. Classification of the common igneous rocks by means of their chemical composition. A provisional attempt. Neues Jahrb. Mineral. Monatsh. 1, 1-15.

Sun, S.S. and McDonough, W.F., 1989. Chemical and isotopic systematics of oceanic basalts: implications for mantle composition and processes. Geological Society, London, Special Publications, 42(1), pp.313-345.

Takazawa, E., Okayasu, T. and Satoh, K., 2003. Geochemistry and origin of the basal lherzolites from the northern Oman ophiolite (northern Fizh block). Geochemistry, Geophysics, Geosystems, 4(2).

Tikoff, Basil, Greene, David, 1997. Stretching lineations in transpressional shear zones: an example from the Sierra Nevada Batholith, California. Journal of structural geology 19 (1), 2939. doi:https://doi.org/10.1016/S0191-8141(96)00056-9. 
Toteu, S.F., Van Schmus, W.R., Penaye, J. and Michard, A., 2001. New U-Pb and Sm-Nd data from north-central Cameroon and its bearing on the pre-Pan African history of central Africa. Precambrian Research, 108(1-2), pp.45-73.

Trompette, R., 1994. In: Carozzi, A.V. (Ed.), Geology of western Gondwana (2000-500 Ma): PanAfrica-Brasiliano aggregation of South America and Africas, 1st ed. CRC Press. https://doi.org/10.1201/9781003077664.

Ulrich, M., Picard, C., Guillot, S., Chauvel, C., Cluzel, D. and Meffre, S., 2010. Multiple melting stages and refertilization as indicators for ridge to subduction formation: The New Caledonia ophiolite. Lithos, 115(1-4), pp.223-236.

Uysal, I., Ersoy, E.Y., Dilek, Y., Escayola, M., Sarıfakıŏglu, E., Saka, S. and Hirata, T., 2015. Depletion and refertilization of the Tethyan oceanic upper mantle as revealed by the early Jurassic Refahiye ophiolite, NE Anatolia-Turkey. Gondwana Research, 27(2), pp.594-611.

Uysal, I., Ersoy, E.Y., Dilek, Y., Kapsiotis, A. and Sarıfakıŏlu, E., 2016. Multiple episodes of partial melting, depletion, metasomatism and enrichment processes recorded in the heterogeneous upper mantle sequence of the Neotethyan Eldivan ophiolite, Turkey. Lithos, 246, pp.228-245.

Uysal, İ., Ersoy, E.Y., Karsl1, O., Dilek, Y., Sadıklar, M.B., Ottley, C.J., Tiepolo, M. and Meisel, T., 2012. Coexistence of abyssal and ultra-depleted SSZ type mantle peridotites in a Neo-Tethyan Ophiolite in SW Turkey: Constraints from mineral composition, whole-rock geochemistry (majortrace-REE-PGE), and Re-Os isotope systematics. Lithos, 132, pp.50-69.

Vernières, J., Godard, M. and Bodinier, J.L., 1997. A plate model for the simulation of trace element fractionation during partial melting and magma transport in the Earth's upper mantle. Journal of Geophysical Research: Solid Earth, 102(B11), pp.24771-24784.

Vils, F., Müntener, O., Kalt, A. and Ludwig, T., 2011. Implications of the serpentine phase transition on the behaviour of beryllium and lithium-boron of subducted ultramafic rocks. Geochimica et Cosmochimica Acta, 75(5), pp.1249-1271.

Vils, F., Pelletier, L., Kalt, A., Müntener, O. and Ludwig, T., 2008. The lithium, boron and beryllium content of serpentinized peridotites from ODP Leg 209 (Sites 1272A and 1274A): implications for lithium and boron budgets of oceanic lithosphere. Geochimica et Cosmochimica Acta, 72(22), pp.5475-5504. 
Wang, Z., Liu, Y., Zong, K., Lin, J. and Kusky, T.M., 2020. Mantle degassing related to changing redox and thermal conditions during the Precambrian supercontinent cycle. Precambrian Research, 350, p.105895.

Warren, J.M., 2016. Global variations in abyssal peridotite compositions. Lithos, 248, pp.193-219. Wicks, F.J. and Whittaker, E.J.W., 1977. Serpentine textures and serpentinization. The Canadian Mineralogist, 15(4), pp.459-488.

Wiedenbeck, M., Hanchar, J.M., Peck, W.H., Sylvester, P., Valley, J., Whitehouse, M., Kronz, A., Morishita, Y., Nasdala, L., Fiebig, J. and Franchi, I., 2004. Further characterisation of the 91500 zircon crystal. Geostandards and Geoanalytical Research, 28(1), pp.9-39.

Wiedenbeck, M.A.P.C., Alle, P., Corfu, F., Griffin, W.L., Meier, M., Oberli, F.V., Quadt, A.V., Roddick, J.C. and Spiegel, W., 1995. Three natural zircon standards for U-Th-Pb, Lu-Hf, trace element and REE analyses. Geostandards newsletter, 19(1), pp.1-23.

Workman, R.K. and Hart, S.R., 2005. Major and trace element composition of the depleted MORB mantle (DMM). Earth and Planetary Science Letters, 231(1-2), pp.53-72.

Wunder, B., Wirth, R. and Gottschalk, M., 2001. Antigorite pressure and temperature dependence of polysomatism and water content. European Journal of Mineralogy, 13(3), pp.485-496. DOI: 10.1127/0935-1221/2001/0013-0485

You, C.F., Castillo, P.R., Gieskes, J.M., Chan, L.H. and Spivack, A.J., 1996. Trace element behavior in hydrothermal experiments: Implications for fluid processes at shallow depths in subduction zones. Earth and Planetary Science Letters, 140(1-4), pp.41-52.

Zou, H., 1998. Trace element fractionation during modal and nonmodal dynamic melting and open-system melting: A mathematical treatment. Geochimica et Cosmochimica Acta 62 (11), 1937-1945. doi:https://doi.org/10.1016/S0016-7037(98)00115-X. 


\section{Figure captions:}

Figure 1: a) Location of the investigated zone in the West Gondwana orogen at the end of the Neoproterozoic. b) Simplified architectural features of the Tuareg shield. c) Geological map of central-western part of the Hoggar adapted after the 1:1000000-scale synthesis map (Meriem et al., 2004) and from 1:200000-scale Tin Felki, In-Aghabir, Silet and Tibehaouine maps (EREM). Location of studied areas (Figures 2a and 2b) are indicated. Colours are: 1- Quaternary cover; 2Cenozoic volcanism; 3-Taourirt Alkaline granitoids; 4- High K-calc-alkaline granitoids; 5Serpentinites; 6- Talc-schist formations; 7- Molassic formations (pelitic-limestone); 8- Sandstonepelitic formations; 9- magmatic and sedimentary formations; 10- tonalite-trondhjemitegranodiorite; 11- Platform-type formations; 12- Paleoproterozoic undifferentiated formations; 13 Geophysical major shear zones are from Brahimi et al. (2018); 14- Pharusian belt. Abbreviation's names are: WA: West African craton; S: Saharan metacraton; A: Amazonian craton; SF: São Francisco craton; C: Congo craton; K: Kalahari craton; RP: Rio de la Plata craton; TZ: Tin Zaouatene; IT: In-Tedeini; Si: Silet; Ao: Aouilene.

Figure 2: a) Updated geological map and structural setting of serpentinite massifs from North InTedeini area. b) Updated geological map and structural setting of Serpentinite massifs from South In-Tedeini area. c) Geological cross-section across the North In-Tedeini area. Colours in the figures $\mathbf{a}$ and $\mathbf{b}$ are the same as in Figure 1. Interactive map file (.kmz) containing the sample locations of the most important areas described is provided in Supplementary data 1.

Figure 3: a) Satellite images of the three largest investigated serpentinite outcrops; Lensoidal shape of the outcrops indicate a sinistral sense of shear; GIS open access Source: Esri, DigitalGlobe, GeoEye, Earthstar Geographics, CNES/Airbus DS, USDA, USGS, AeroGRID, IGN, and the GIS User Community; see also the map (.kmz) in the Supplementary data 1. Field photographs of: b) massive serpentinite structuration in In-Tamerouelt, delimited by sheared serpentinites and talc-schists into its margins and in some corridors. Blue lines are inferred lines to separate massive serpentinites and schistosity; Yellow dashed lines follow the foliation trajectory. c) Brownish-black serpentinite-enclave into Tibehaouine blue-black serpentinite massif in South In-Tedeini massifs; a hand-sample is also shown. d) Chloritite outcrop from south 
Aderniba; a hand sample with euhedral magnetite visible. (For interpretation of the references to color in this figure legend, the reader is referred to the web version of this article).

Figure 4: Orientation data (lower-hemisphere equal-angle stereographic projections in Stereonet11) of structural elements measured in the serpentinites, talc-schist and magmaticsedimentary zones from In-Tedeini massifs, including poles to foliation and fold planes, mineral lineations and fold axes.

Figure 5: a) Asymmetric serpentinite lenses showing a top to the NW sense of thrusting in South In-Tedeini area. b) Sheared serpentinites within a talc-schist zone, showing a top to the NW sense of thrusting in North In-Tedeini area. c) NE-dipping folds in volcano-sedimentary formations in contact with subvertical foliated talc-schist from South In-Tedeini area. d) Serrated and parasitic folds overturned toward the west, associated with penetrative axial plane schistosity dipping toward NE in North In-Tedeini. (e, f) Parasitic folds in vertically foliated amphibolites from North In-Tedeini area.

Figure 6: a) Subvertical foliation in epidotitic-amphibolite formations, associated with horizontal to shallowly SE-plunging mineral stretching lineation. b) Subvertical talc-schist plane associated with horizontal and SSE-plunging mineral stretching lineation. c) Anastomosed talc-schist lenses from South In-Tedeini area, (d, e) asymmetric serpentinite lenses, and (f, $\mathbf{g}, \mathbf{h})$ asymmetric talc, quartzite, amphibolite lenses displaying a sinistral sense of shear.

Figure 7: a) Pseudomorphic texture in In-Tedeini serpentinites matrix. b) Impregnated porphyroblastic bastite in an interpenetrative antigorite matrix. c) Interpenetrative antigoritized matrix of the studied serpentinite (Iharhi locality). d) A vein of lizardite cutting an interpenetrative matrix of antigorite. e) Antigorite relic in the talc-schist formation. f) Back scattered electron coupled to the SEM images of Chromian spinel crystal preserved in a core and rimmed by a magnetite in serpentinite matrix (Reflected light images). Element distribution maps of $\mathrm{Cr}, \mathrm{Al}$ and $\mathrm{Fe}$ on $\mathrm{Cr}$-spinel in the studied serpentinites. g) Clinochlore matrix of a chloritite dike (SAM-8, south Aderniba) with BSE images of zircon grains (see also Figure 14). Abbreviations correspond 
to Chrome-spinel (Cr-Sp), Bastite (Bst), Antigorite (Atg), Magnesite (Mgs), Lizardite (Liz), Talc (Tlc), Magnetite (Mgt), Clinochlore (Clc).

Figure 8: Low $\left(100-1200 \mathrm{~cm}^{-1}\right)$ and high $\left(3600-3750 \mathrm{~cm}^{-1}\right)$ frequency Raman spectrum of representative serpentine phases in the studied area. In the green line are indicated peaks detection of antigorite as a main serpentine phase in the matrix and in bastite pseudomorphs; veinlets crosscutting antigorite blades are composed of a mixture of antigorite with chrysotile in the blue spectrum and with lizardite in the red one. (For interpretation of the references to color in this figure legend, the reader is referred to the web version of this article).

Figure 9: Spinel compositions of the serpentinite samples plotted on a) $\mathrm{Cr}_{2} \mathrm{O}_{3}$ vs. $\mathrm{Al}_{2} \mathrm{O}_{3}$ contents (wt\%) diagram. Mantle array and arc-cumulates fields are after Franz and Wirth (2000); b) Cr\# $[\mathrm{Cr} /(\mathrm{Cr}+\mathrm{Al})]$ vs. $\mathrm{Mg} \#\left[\mathrm{Mg} /\left(\mathrm{Mg}+\mathrm{Fe}^{2+}\right)\right]$ cationic ratio diagram. The partial melting trend (orange arrow) is from Arai (1994); c) $\mathrm{Cr} \#$ ratio vs. $\mathrm{TiO}_{2}$ content (Wt\%) diagram. Melting trend is from Hellebrand et al. (2001) and Uysal et al. (2012). FMM is Fertile Mid-ocean-ridge Mantle (Pearce and Parkinson, 1993). d) Al-Cr-Fe ${ }^{3+}$ ternary variation diagram. Gray field of abyssal peridotites after Warren (2016); Blue fields for mantle wedge peridotites after Ishii et al. (1992) and Parkinson and Pearce (1998). Only primary cores analyses are represented here and have been considered for petrogenetic interpretations. e) Microprobe analyses of serpentine phases plotted in Al vs. Si cation contents diagram. Compilation of antigorite in Eclogite (Ecg), Amphibolite (Amp), Greenschist (GS) and Blue-schist (BS) facies fields (see Padron-Navarta et al., 2013; Schwartz et al., 2013). (For interpretation of the references to color in this figure legend, the reader is referred to the web version of this article).

Figure 10: Ternary plot of $\mathrm{SiO}_{2}$ - (L.O.I. x10) - $\mathrm{MgO}$ for whole-rock contents of In-Tedeini serpentinites. Oxide concentrations are recalculated on a volatile free basis. Green-yellow gradient and horizontal dashed lines indicate degree of serpentinization towards increasing L.O.I. content. Abbreviations correspond to Forsterite (Fo), Enstatite (En), Serpentine (Serp), Talc (Tlc), Brucite (Brc), Magnesite (Mgs), Dolomite (Dol). (For interpretation of the references to color in this figure legend, the reader is referred to the web version of this article). 
Figure 11: Whole-rock major oxide content (wt \%) plots for the In-Tedeini serpentinites: a) $\mathrm{Al}_{2} \mathrm{O}_{3}$, b) $\mathrm{TiO}_{2}$ and c) $\mathrm{CaO} / \mathrm{Al}_{2} \mathrm{O}_{3}$ weight ratio vs. $\mathrm{MgO}$. Gray field for abyssal peridotites and serpentinites are from Niu (2004), Paulick et al. (2006), Godard et al. (2008), Boschi et al. (2013). Mantle wedge peridotites and serpentinites blue fields are from Lagabrielle et al. (1992), Ishii et al. (1992), Parkinson and Pearce (1998), Savov et al. (2005a, 2007), Kodolányi et al. (2012); Yellow fields of Ocean-continent transitional (OCT) peridotites are from Seifert and Brunotte (1996), Hébert et al. (2001), Kodolányi et al. (2012). Estimated primitive mantle (PM) values are from McDonough and Sun (1995). Colored symbols are the same as Figure 10. (For interpretation of the references to color in this figure legend, the reader is referred to the web version of this article).

Figure 12: $\mathrm{Mg} / \mathrm{Si}$ vs. $\mathrm{Al} / \mathrm{Si}$ weight ratios diagram for In-Tedeini serpentinites. Also shown in comparison the gray field for compositions of abyssal peridotites by Niu (2004) and blue field for mantle wedge peridotites and serpentinites after Ishii et al. (1992), Parkinson and Pearce (1998), Savov et al. (2005), Kodolányi et al. (2012). The dashed black arrow represents the expected compositional change of residual mantle peridotites during partial melting originated from the primitive upper mantle (PM) value of McDonough and Sun (1995). Abbreviations and colored symbols are the same as Figure 10. (For interpretation of the references to color in this figure legend, the reader is referred to the web version of this article).

Figure 13: Chondrite-normalized REE patterns of a) North and c) South In-Tedeini serpentinites. Estimated Chondrite values are from Barrat et al. (2012). Primitive mantle-normalized multielement patterns of b) North and d) South In-Tedeini serpentinites. Estimated primitive mantle values are from McDonough and Sun (1995). In panel $\mathbf{a}$ and $\mathbf{b}$, blue patterns represent talc-schist AD10 from Aderniba locality. In panel c and d, TB-16B purple patterns represent serpentiniteenclave enclosed in Tibehaouine locality. Gray fields for abyssal peridotites and serpentinites are from Niu (2004), Paulick et al. (2006), Godard et al. (2008), Boschi et al. (2013). Blue fields for Mantle wedge peridotites and serpentinites are from Parkinson and Pearce (1998), Savov et al. (2005a, 2007), Kodolányi et al. (2012). Yellow fields for Ocean-continent transitional (OCT) peridotites are from Seifert and Brunotte (1996), Kodolányi et al. (2012). (For interpretation of the references to color in this figure legend, the reader is referred to the web version of this article). 
Figure 14: a) Chondrite-normalized REE patterns of chloritite rocks (See Supplementarydata 4). Estimated Chondrite values are from Barrat et al. (2012). N-MORB-normalized multi-element patterns of chloritite rocks. Estimated N-MORB values are from Sun and McDonough (1989). b) $\mathrm{U}-\mathrm{Pb}$ Concordia diagram of zircon cores from the chloritite dike sample (SAM-8). Cathodoluminescence images of zircon grains are also illustrated. See details in Supplementarydata 5 .

Figure 15: Trace elements (ppm) binary plots for the studied serpentinites: a) Li and b) Pb vs. Cs. Estimated primitive mantle values are from McDonough and Sun (1995). Brown fields for Subducted sediments are from Plank and Langmuir (1998) and Li and Schoonmaker (2003). Colored symbols and fields are the same as Figures 10 and 13, respectively.

Figure 16: Trace elements binary plots for the studied serpentinites: $\mathrm{Sr} v s$. a) $\mathrm{CaO}$ and b) $\mathrm{Ba}(\mathrm{ppm})$ contents. Estimated primitive mantle values are from McDonough and Sun (1995). Beige fields for Carbonate formations are from Boskabadi (2020). Colored symbols and fields are the same as Figures 10 and 13, respectively.

Figure 17: a) $\mathrm{Nb}(\mathrm{ppm})$ vs. chondrite normalized (CN) La/Yb ratio contents of the studied InTedeini serpentinites. Orange arrow represents the refertilization fingerprint after melt/rock interactions for peridotites and green arrow represents the trend reflecting fluid/rock interactions for peridotites. This allows to determine which from hydrothermal and magmatic process better explain LREE enrichments (Fig. 13a, c) in the serpentinites. b) Chondrite-normalized La vs. $\mathrm{Gd} / \mathrm{Yb}$ ratio diagram. Estimated chondrite values are from Barrat et al. (2012). Green field corresponds to the hydrothermalized serpentinites from Hodel et al. (2018, 2020); Eastern Desert (ED) of Egypt serpentinites field is from EI Dien et al. (2016); Araguaia serpentinites field is from Hodel et al. (2019); Anti-Atlas serpentinites field is from Hodel et al. (2020). Other colored fields and symbols are the same as Figures 13 and 10, respectively. (For interpretation of the references to color in this figure legend, the reader is referred to the web version of this article). 
Figure 18: REE melting models illustrated on chondrite-normalized REE patterns and compared to REE compositions of North and South In-Tedeini serpentinites. Closed-system dynamic melting of depleted mantle (DM) source (Black dashed pattern, Workman and Hart, 2005) is shown by gray patterns with melting values. Blue patterns correspond to open-system dynamic melting models simulated after $21 \%$ of DM melting source and a subduction-fluid influx $\beta$ after Eiler et al. (2000, 2007). Orange patterns correspond to refertilization models using melt mass fractions $X$ of island arc basalt n. 4556 (Chikhaoui et al., 1980) and a flux $(\beta=0.05)$ molten residue. Estimated chondrite values are from Barrat et al. (2012). See modelling parameters in Supplementarydata 6. (For interpretation of the references to color in this figure legend, the reader is referred to the web version of this article).

Figure 19: Schematic geodynamic model that we propose for the In-Tedeini serpentinite outcrops, i.e., suture zone related to the closure of the Pharusian-Goiás ocean. It illustrates the subduction stage, in which amounts of slab-derived fluids and melts affected the mantle wedge; and the development of accretionary wedge following by the exhumation of mantle wedge remnants that connects western and central Hoggar. 
Figures

Figure 1

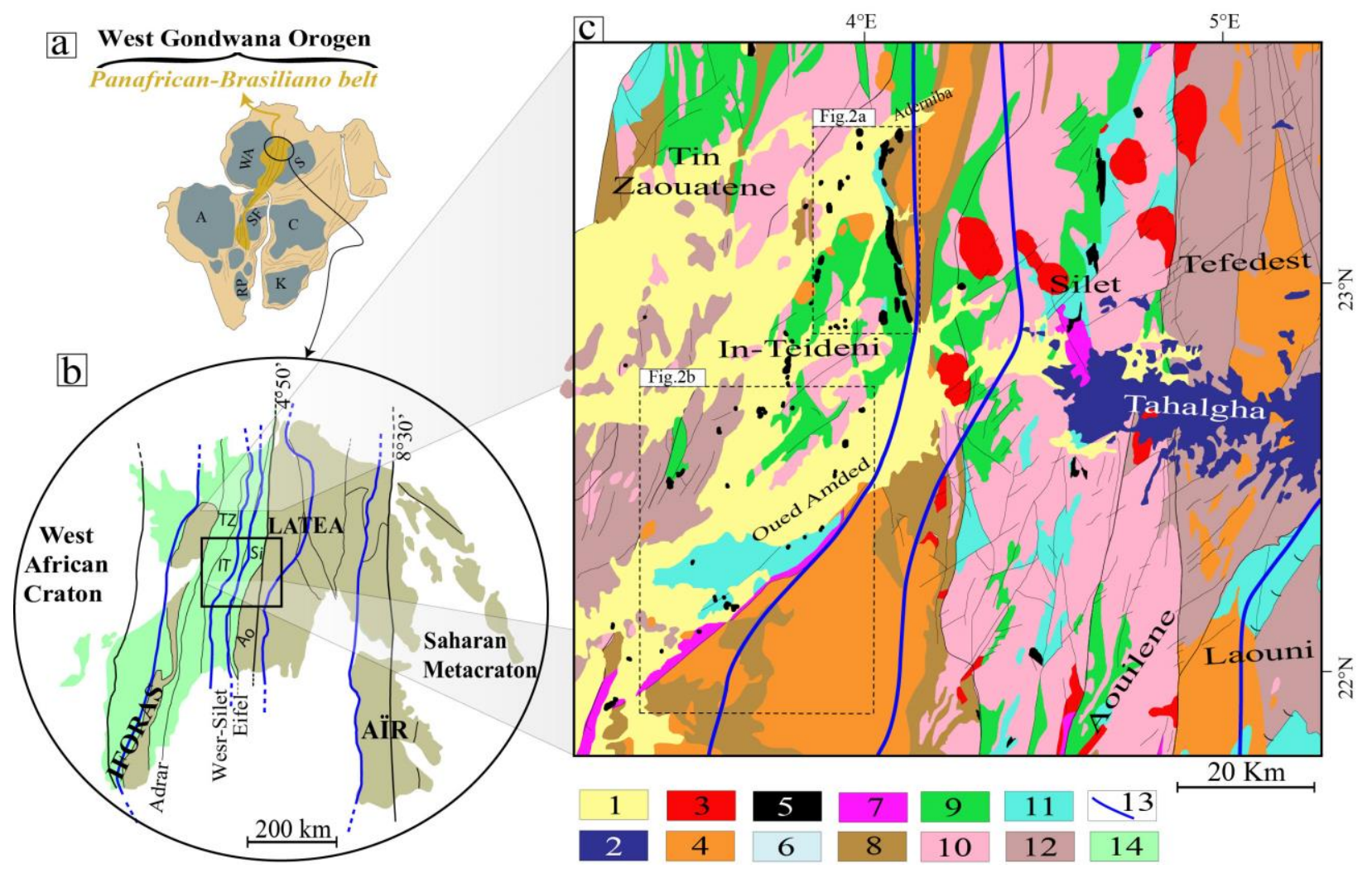


Figure 2
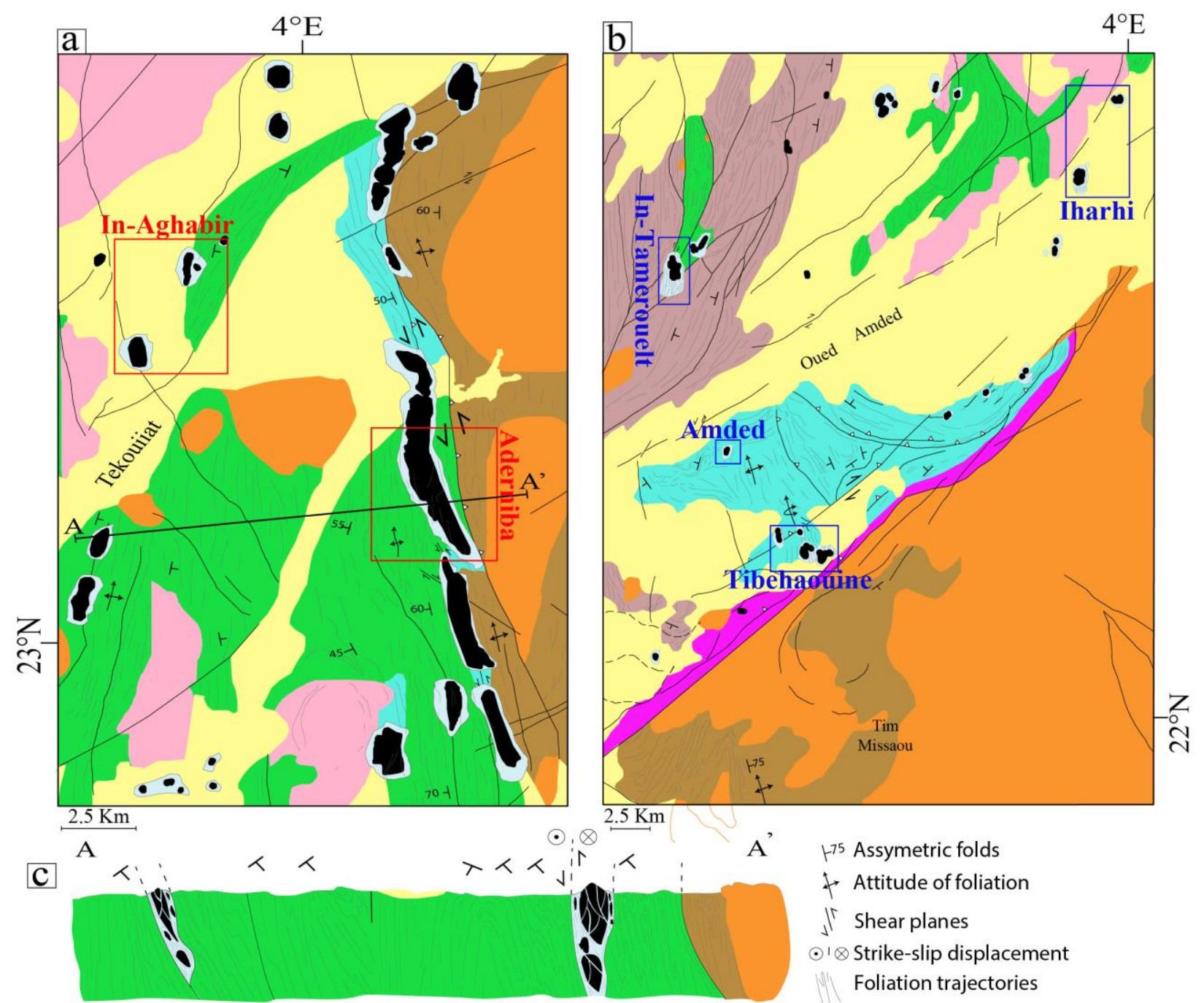
Figure 3

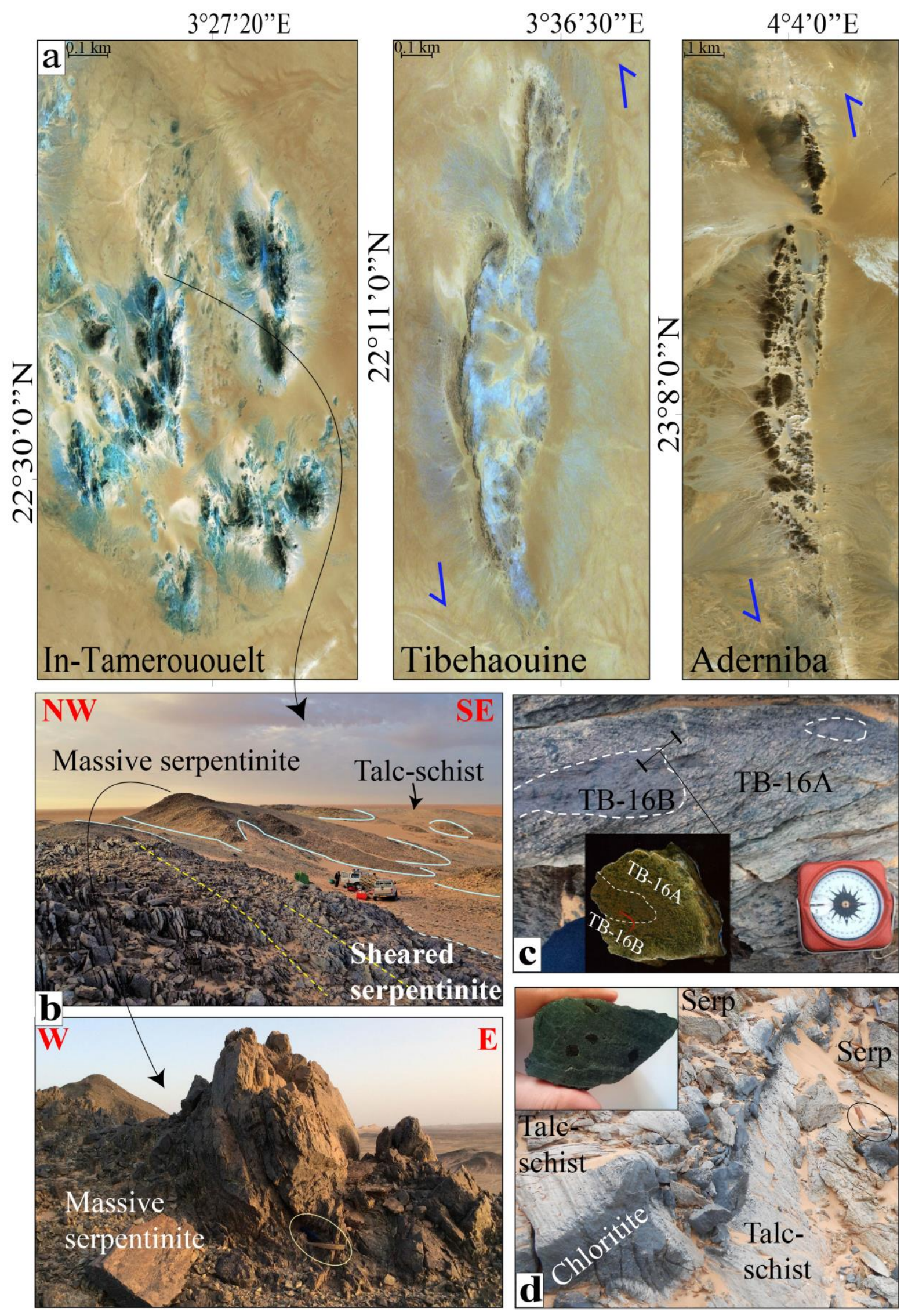


Figure 4
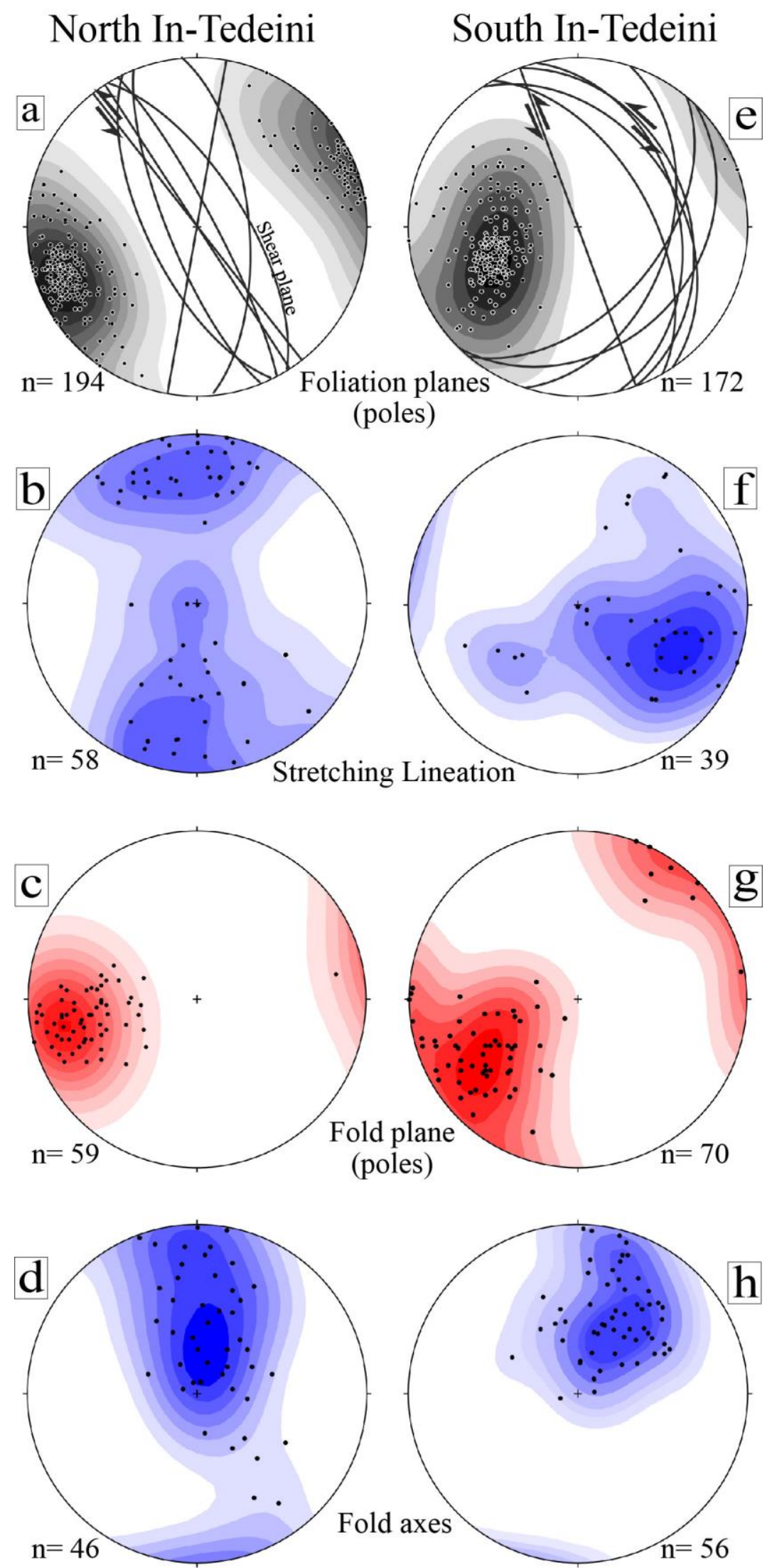


\section{Figure 5}
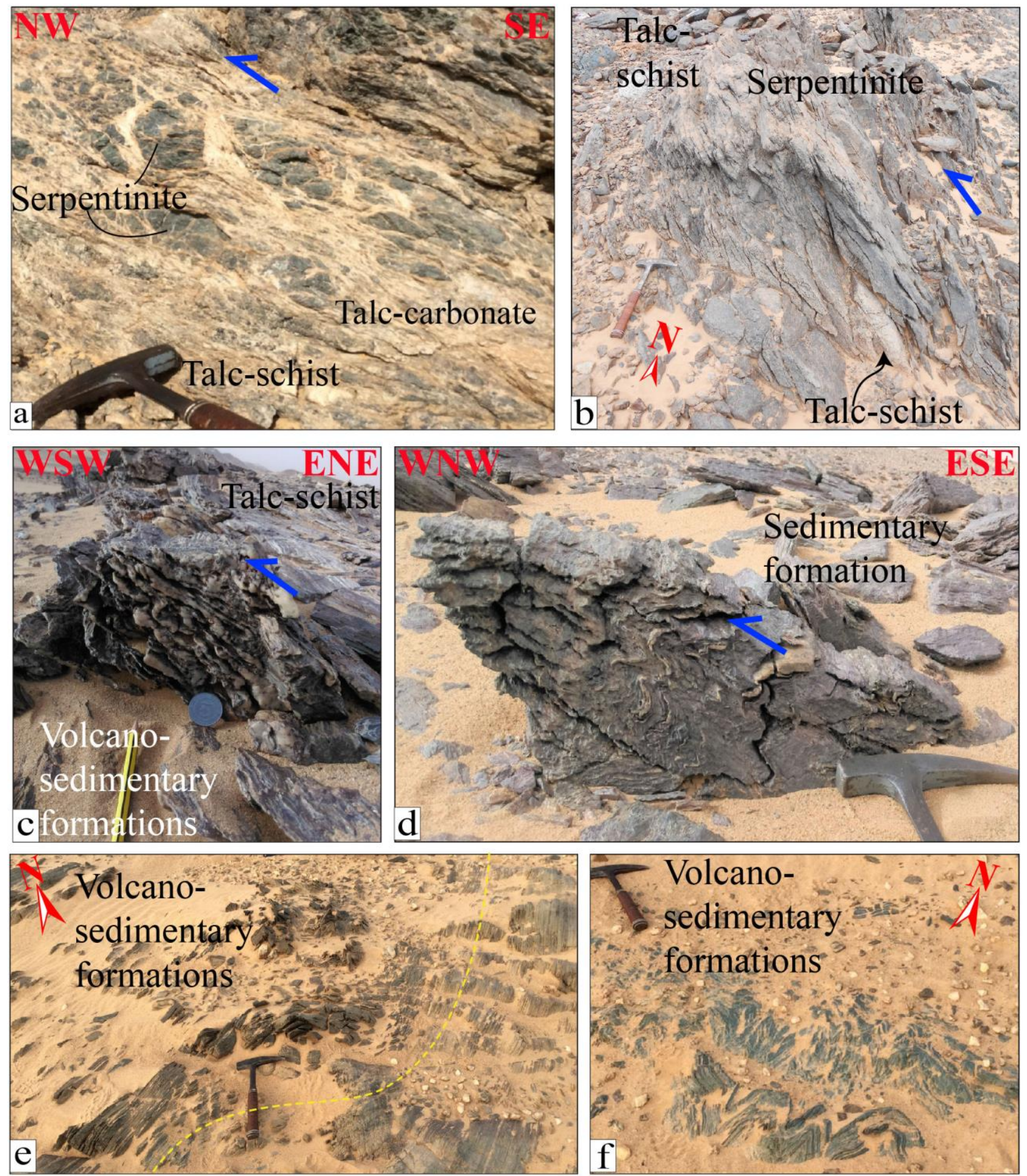


\section{Figure 6}
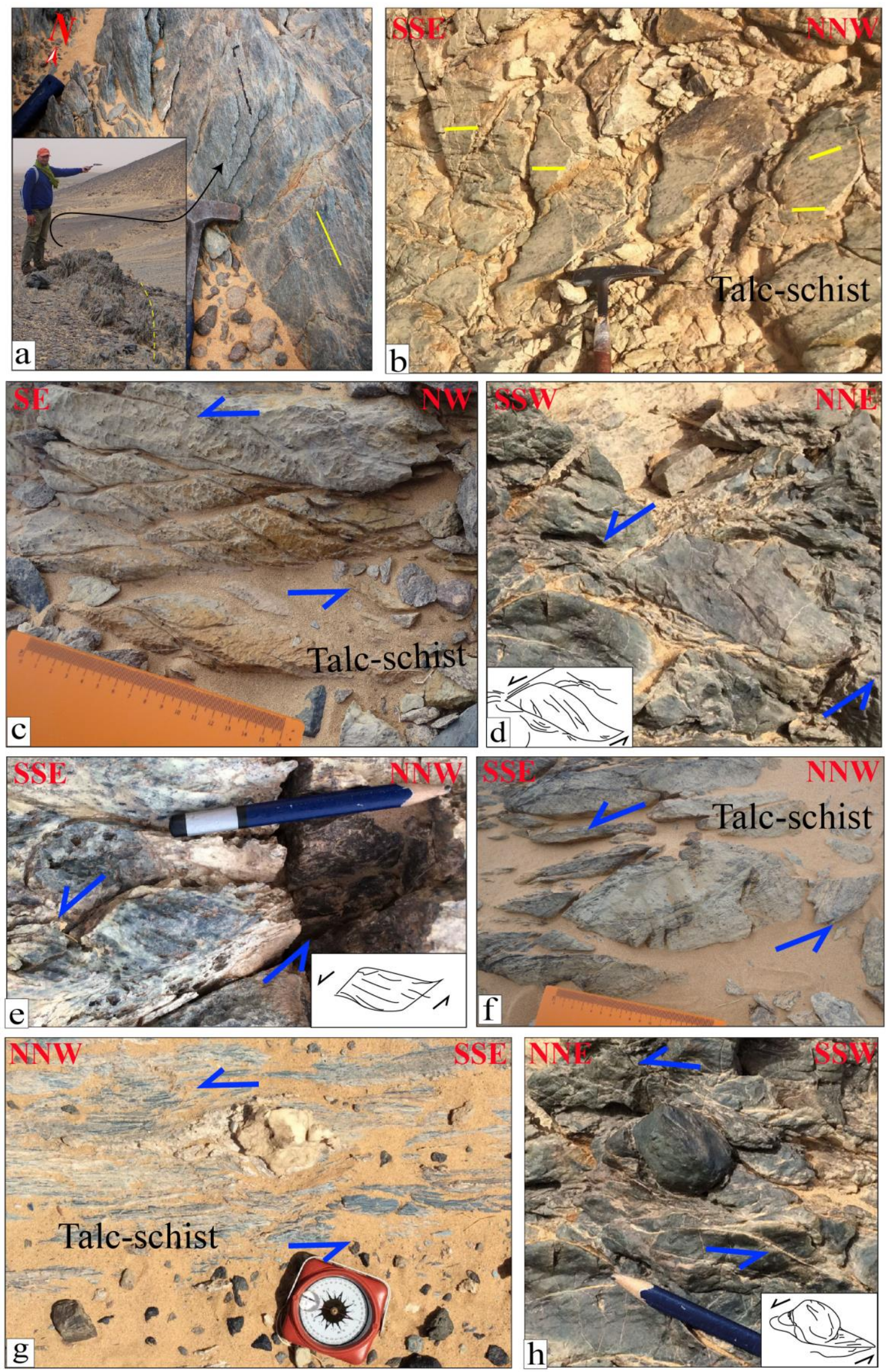
Figure 7
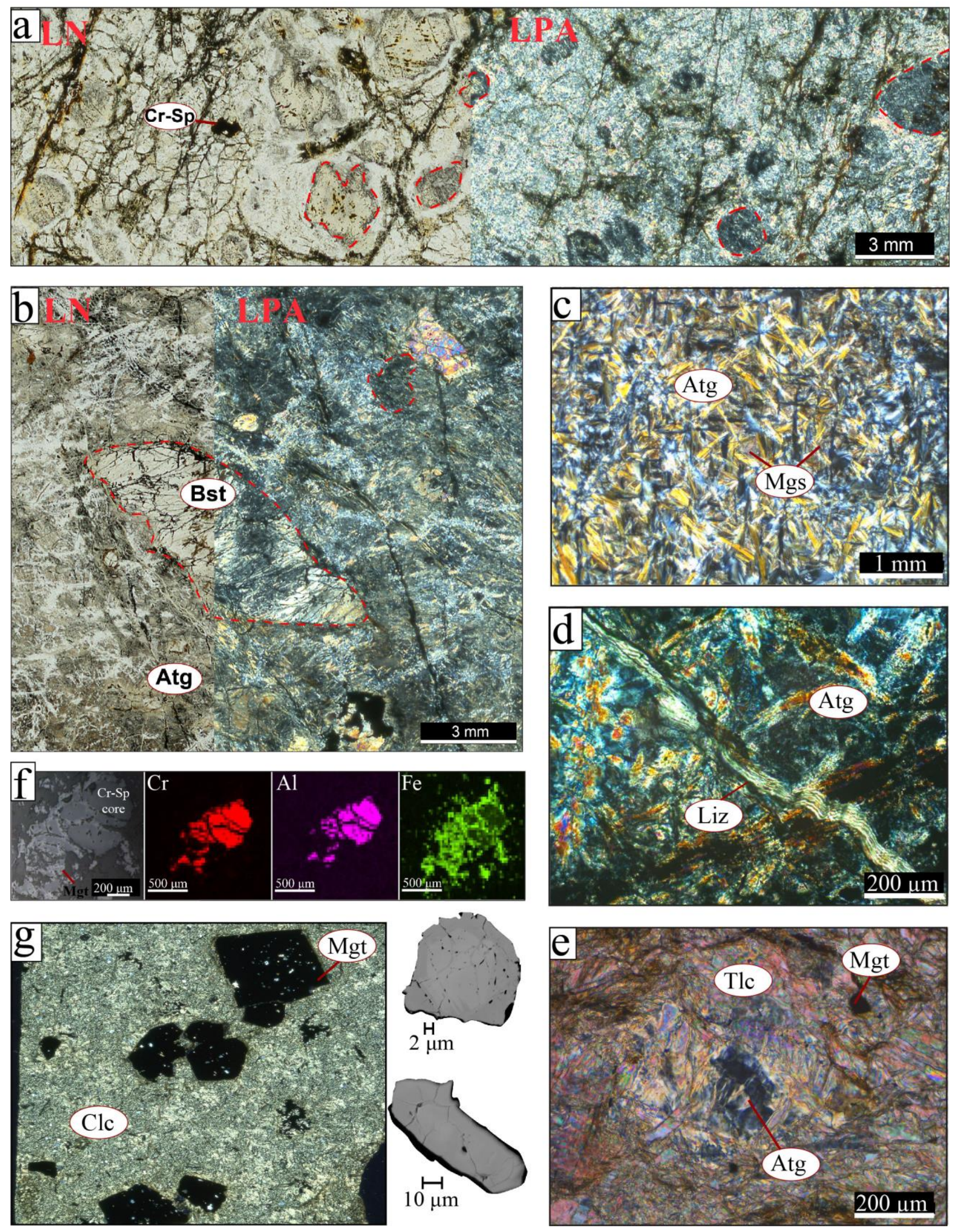
Figure 8

a

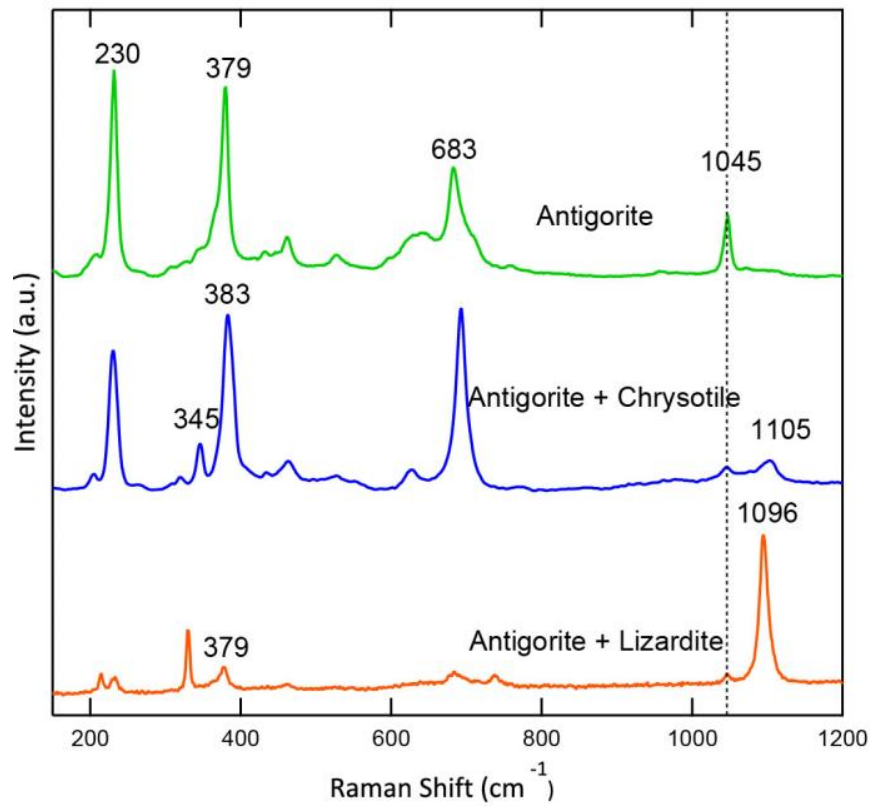

b

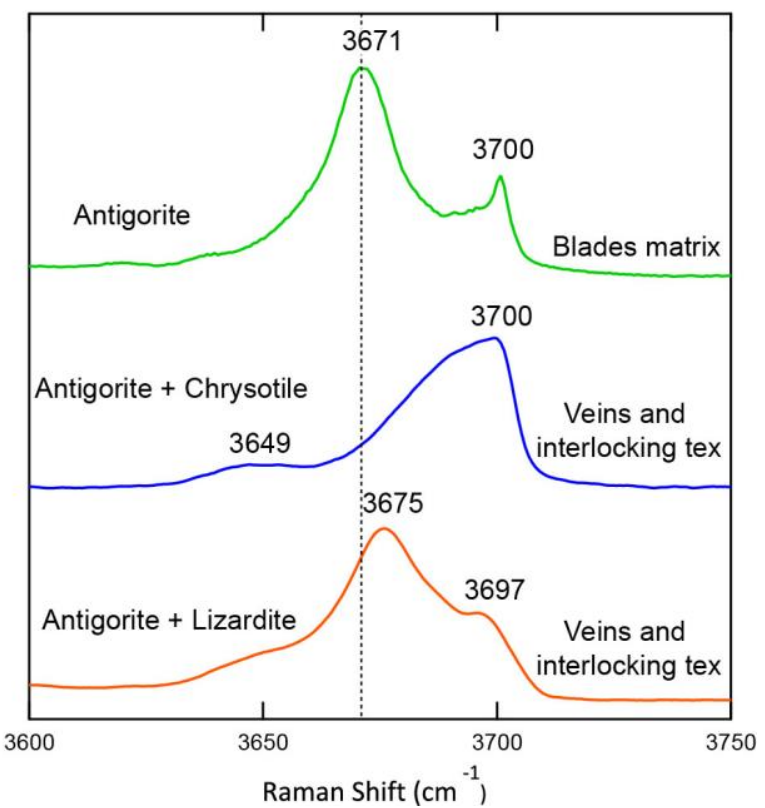

\section{Figure 9}

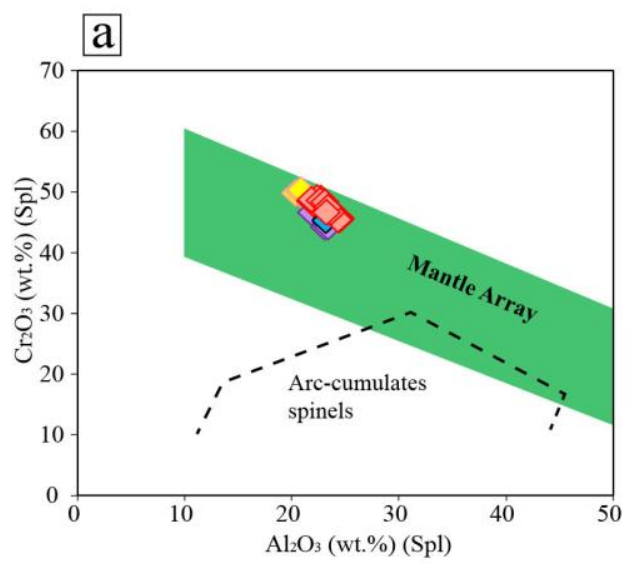

b

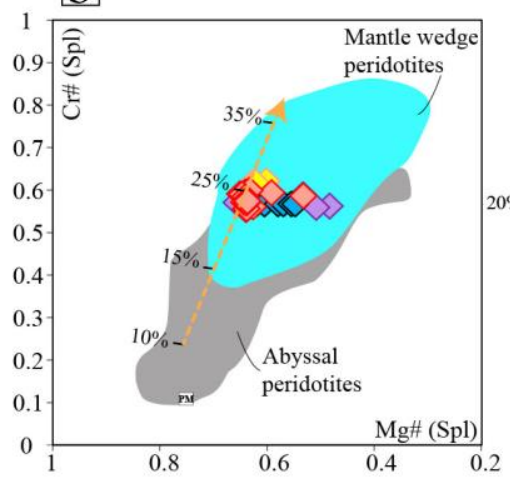

c

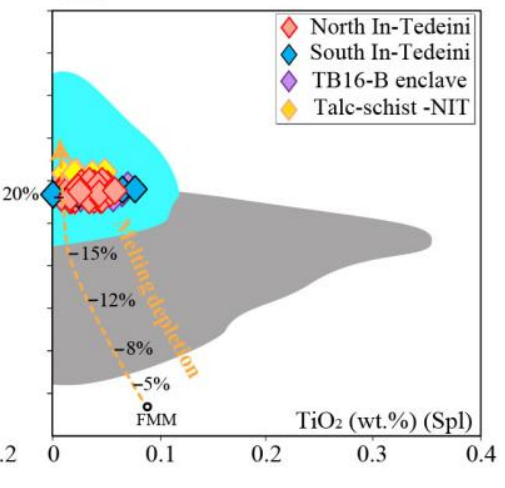

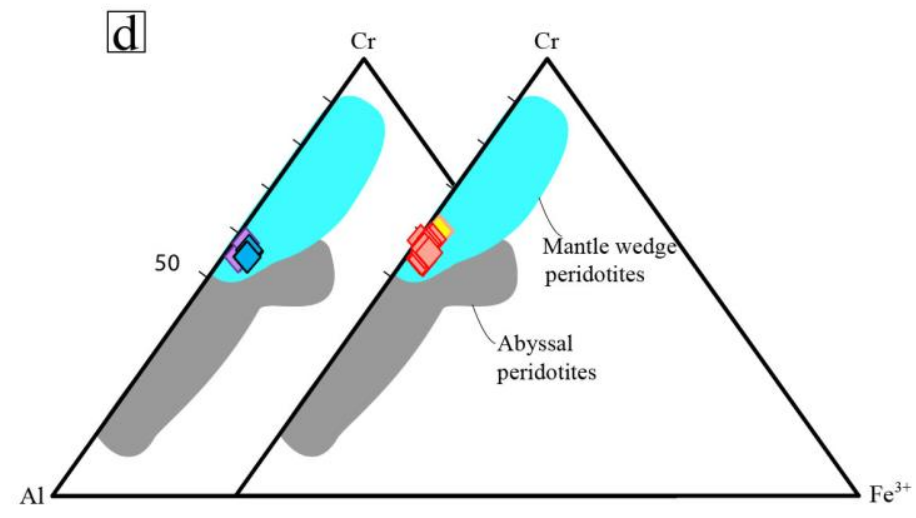

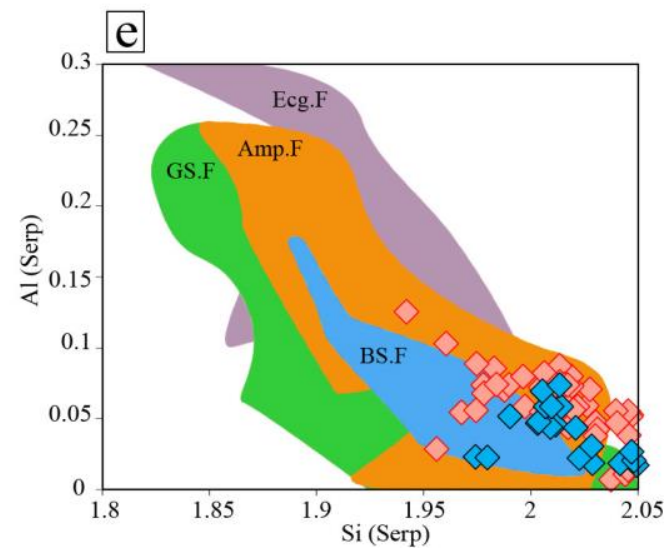


Figure 10

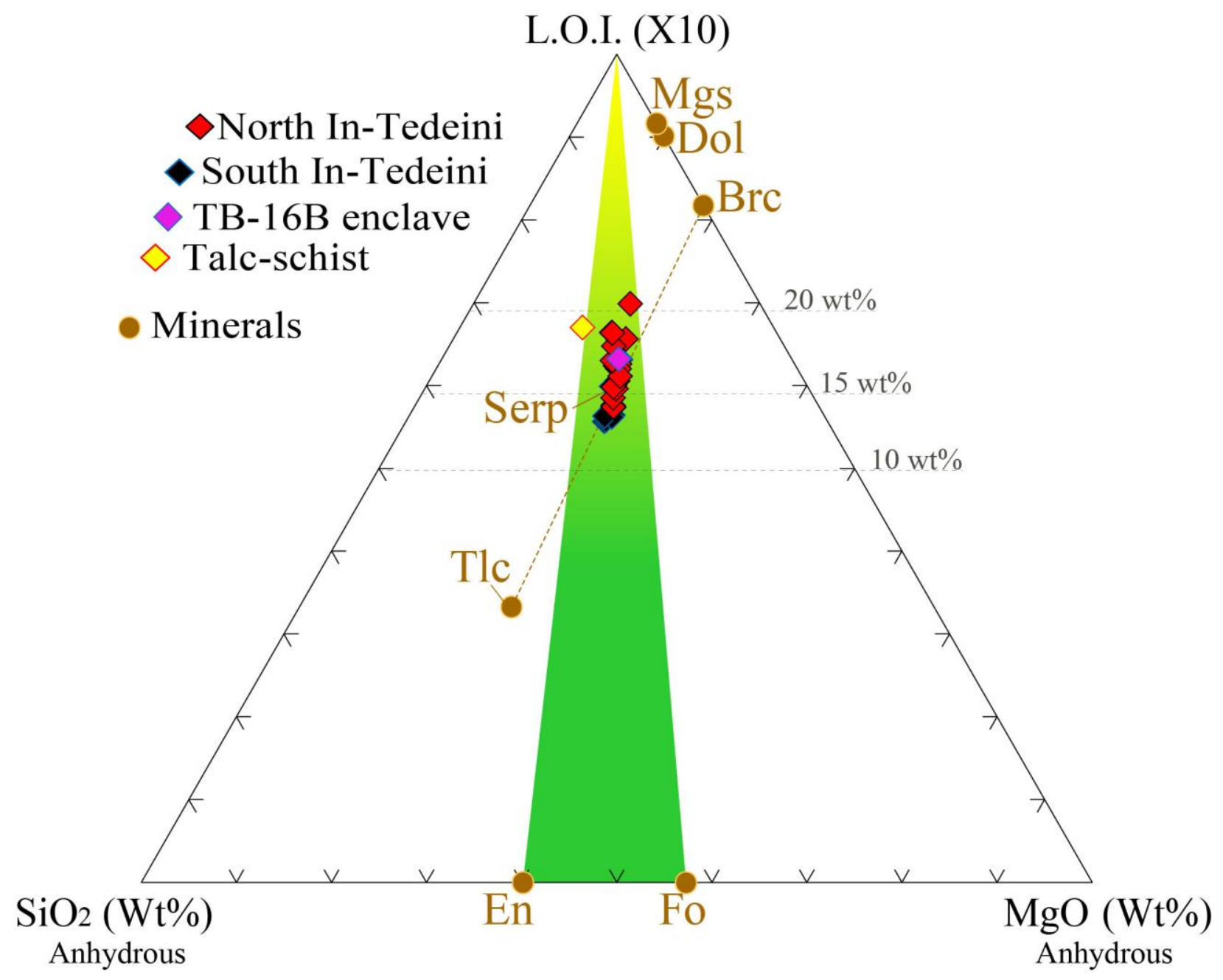


Figure 11
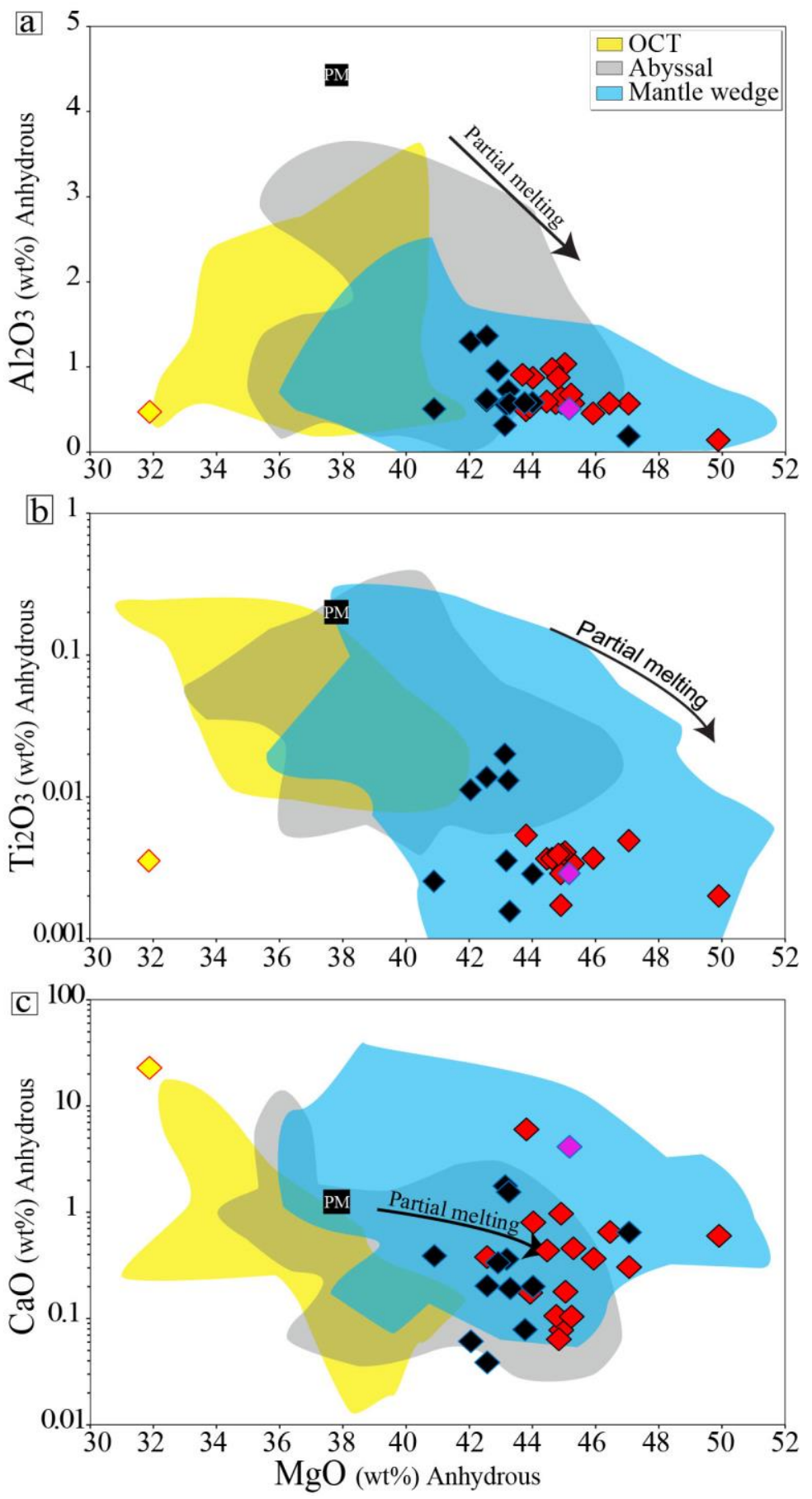


\section{Figure 12}

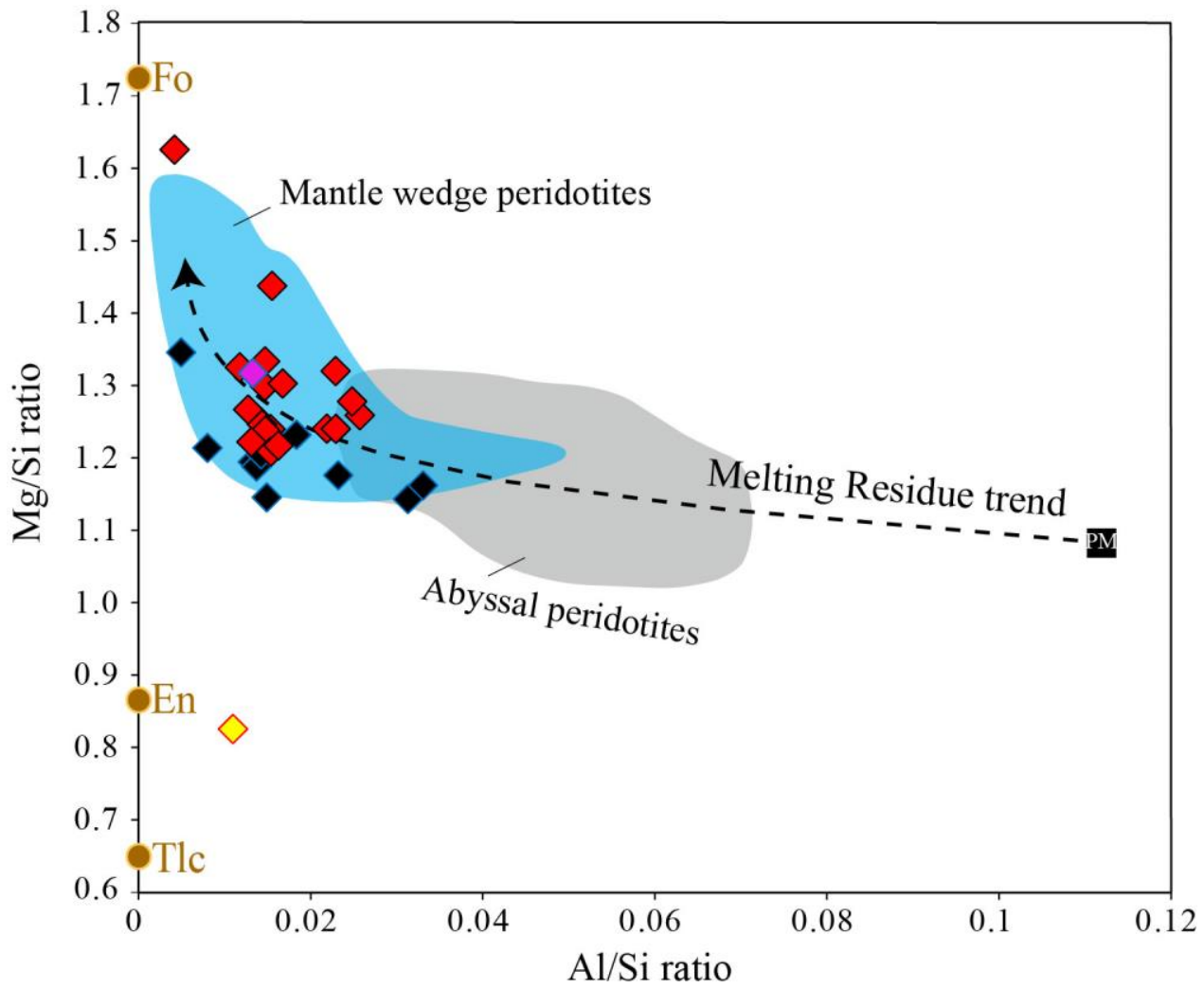

\section{Figure 13}
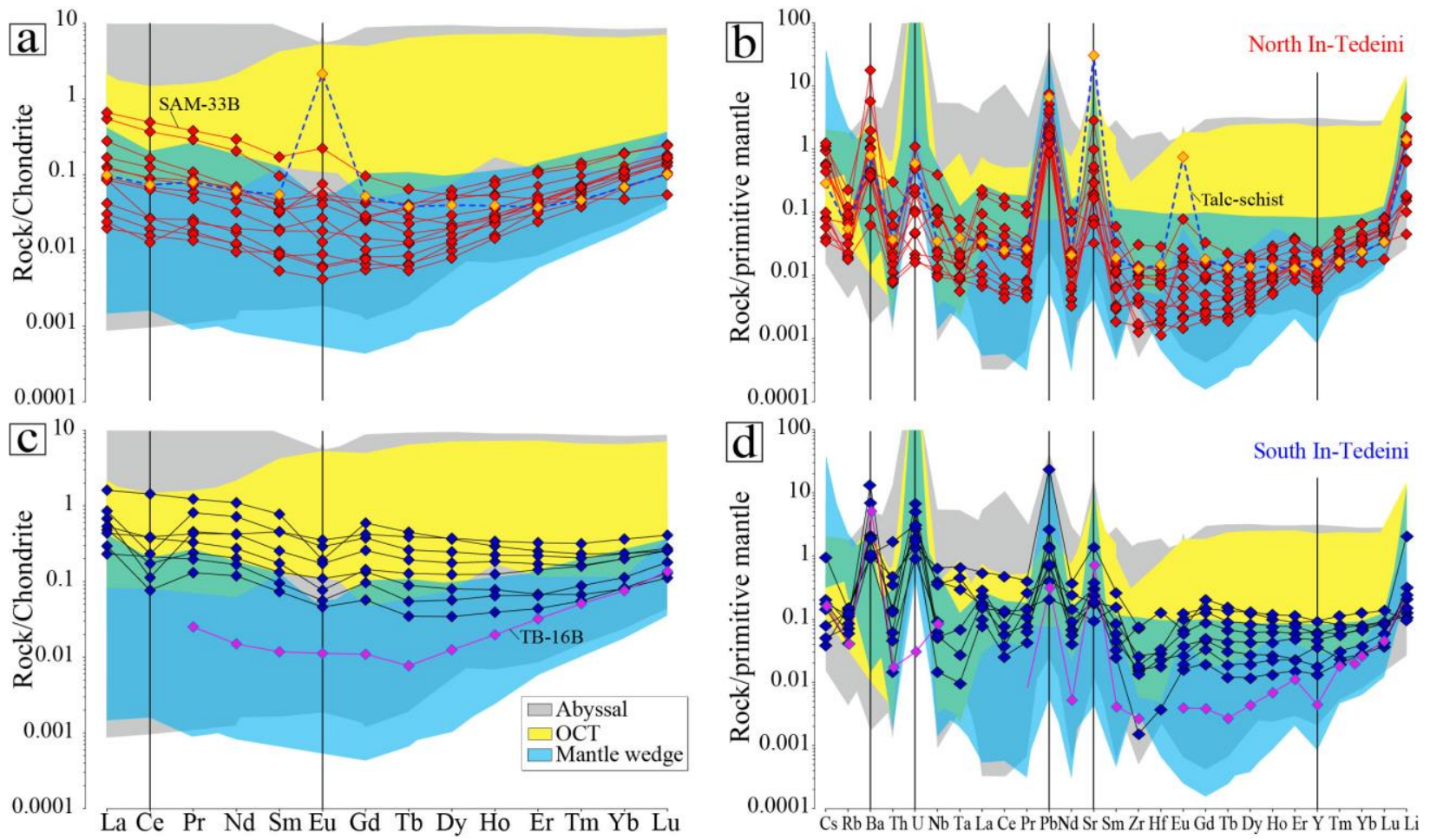
Figure 14

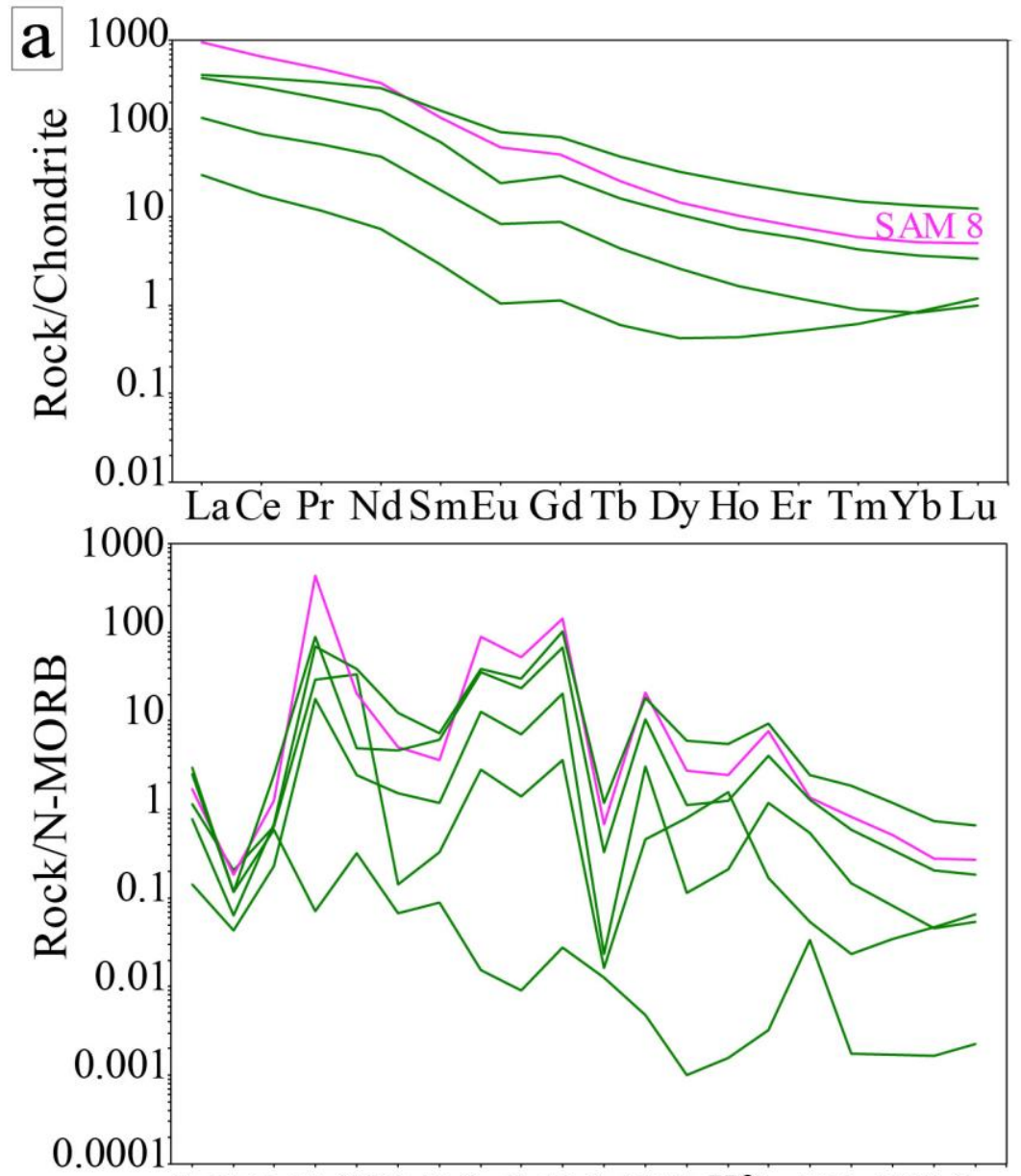

Cs RbBaTh U Nb TaLaCe Pb Sr NdZr HfSmTiDy Y Yb Lu

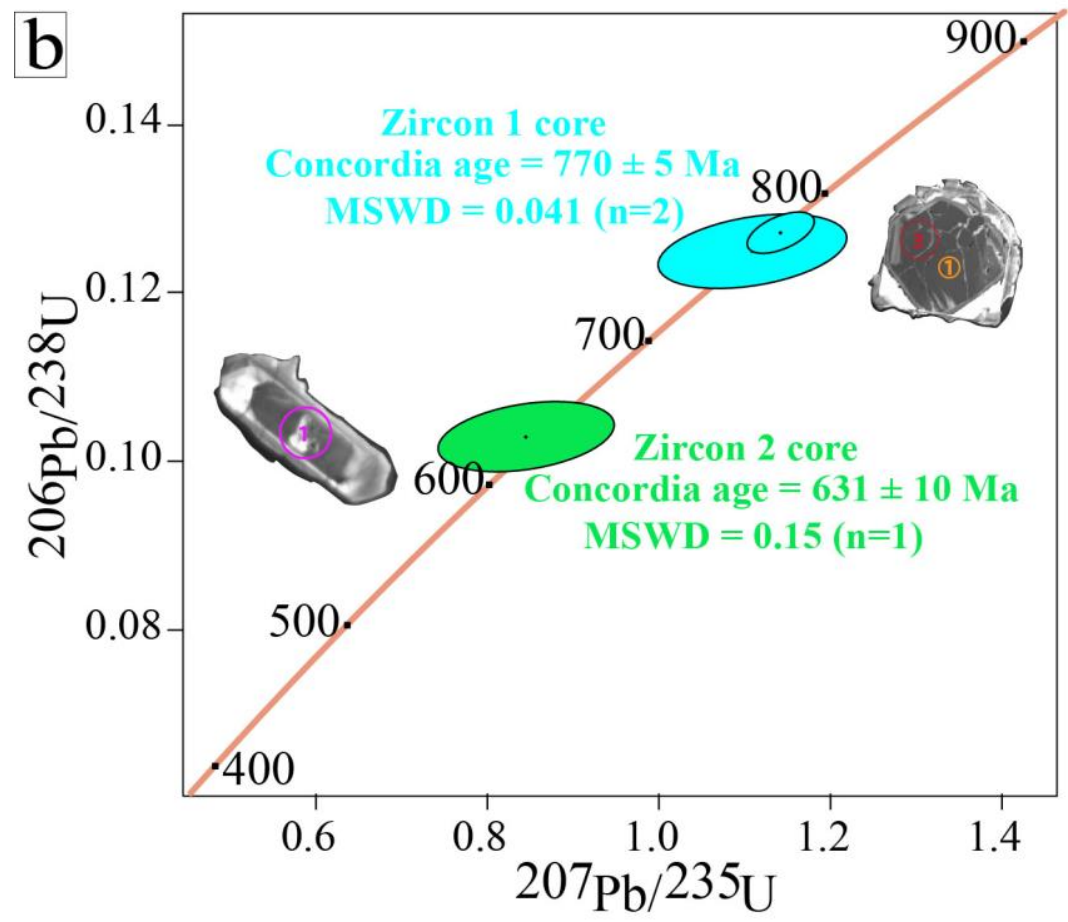


Figure 15
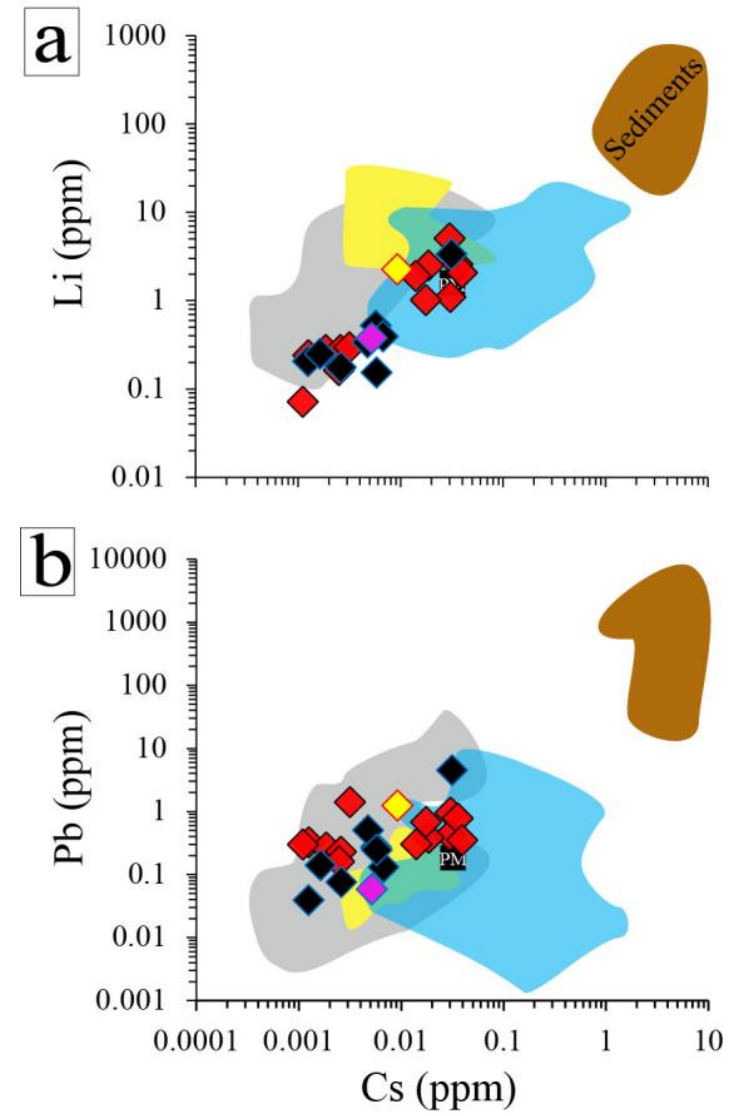

Figure 16
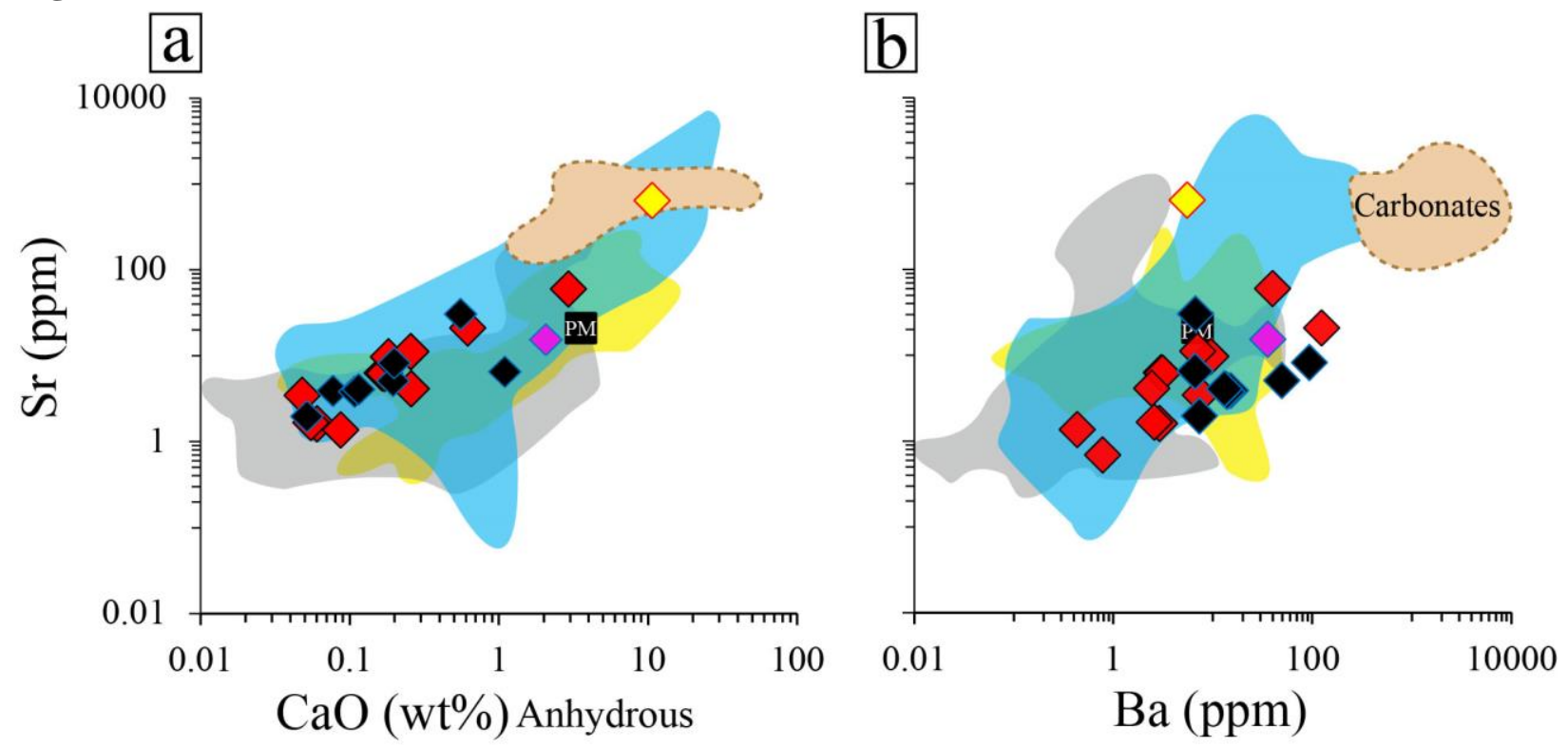
Figure 17

a

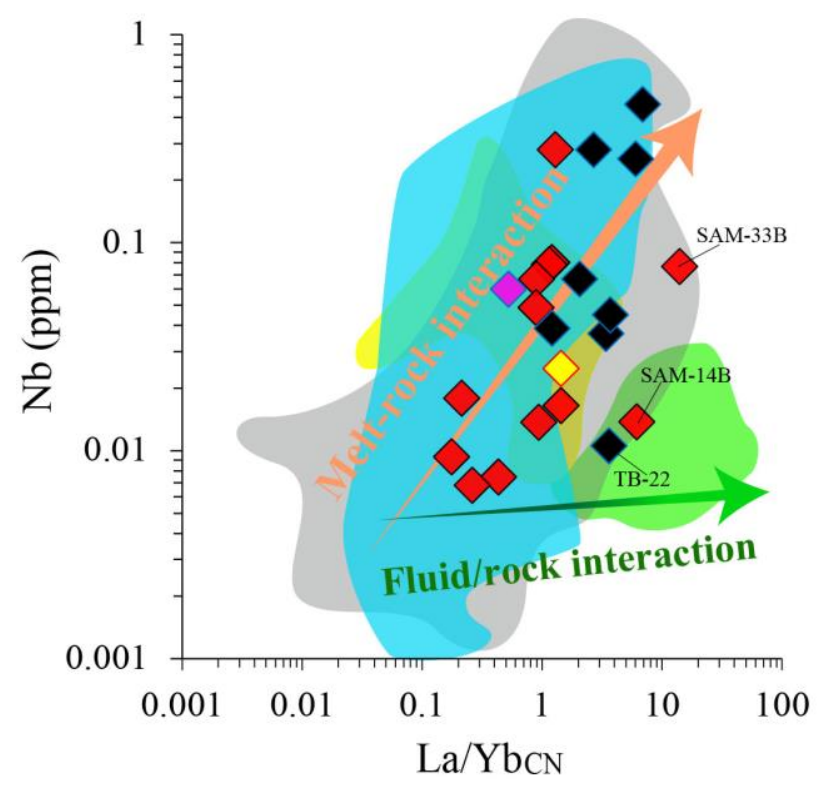

b

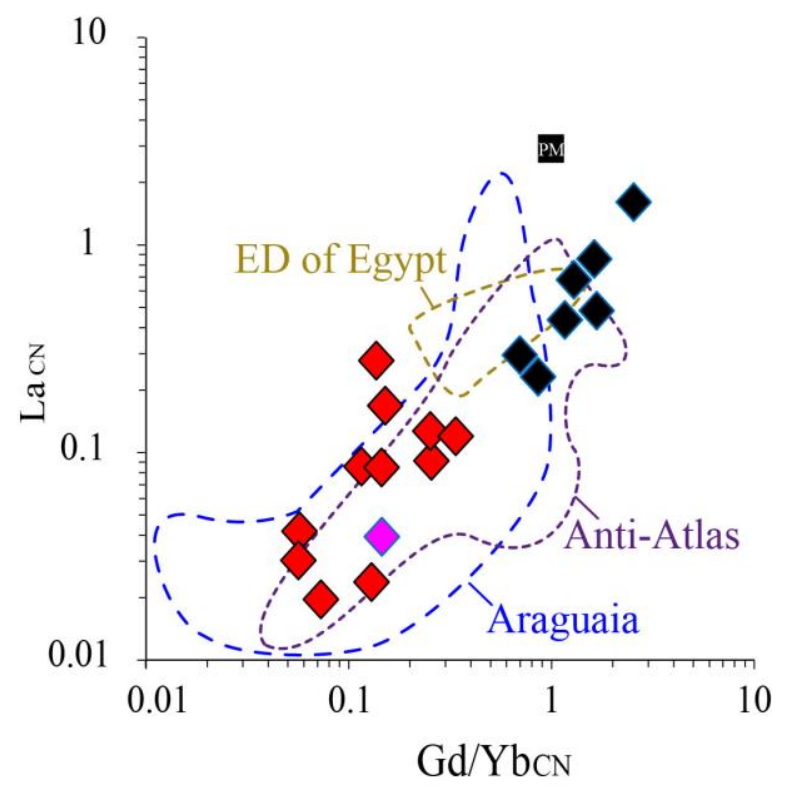




\section{Figure 18}
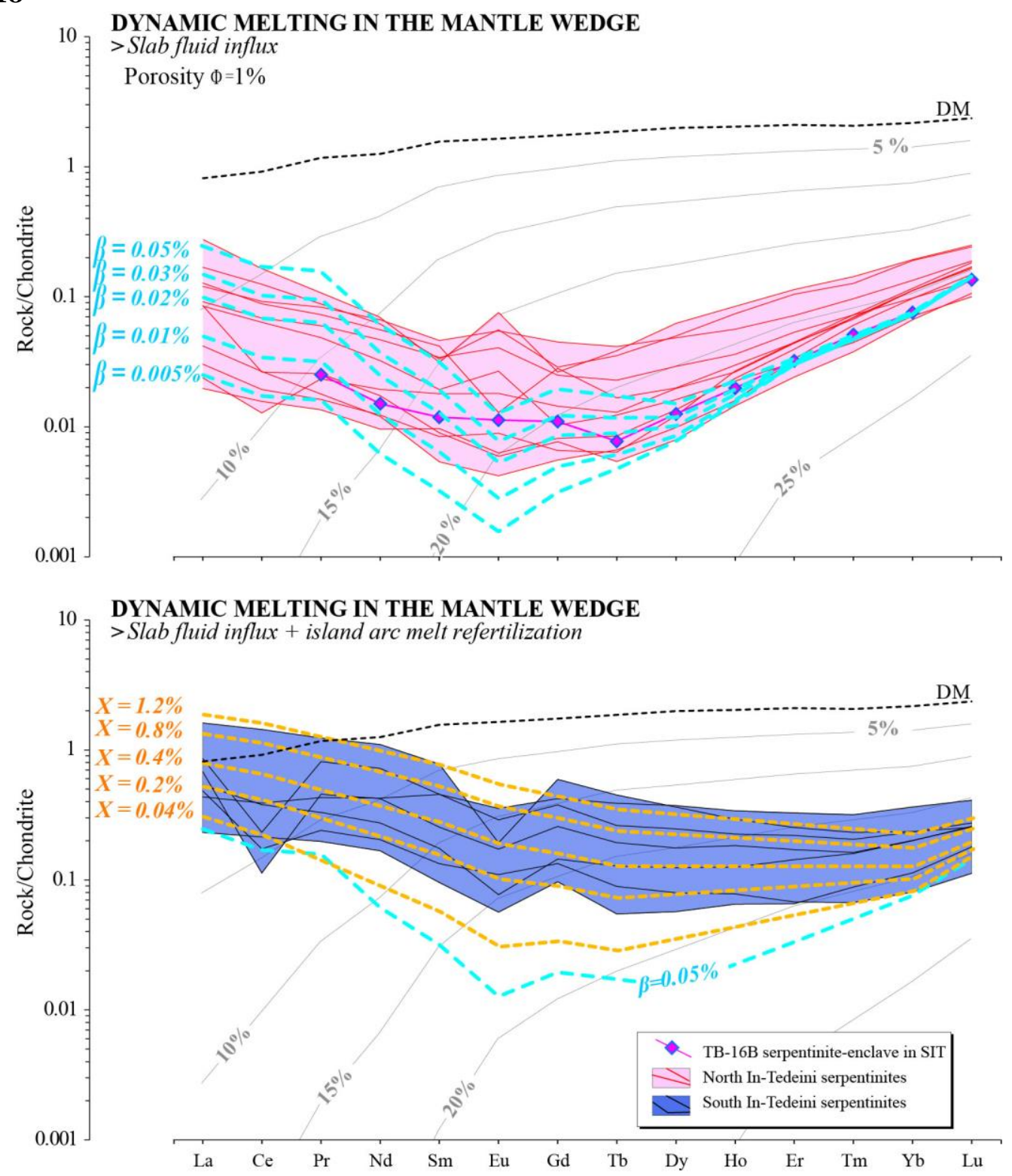
Figure 19

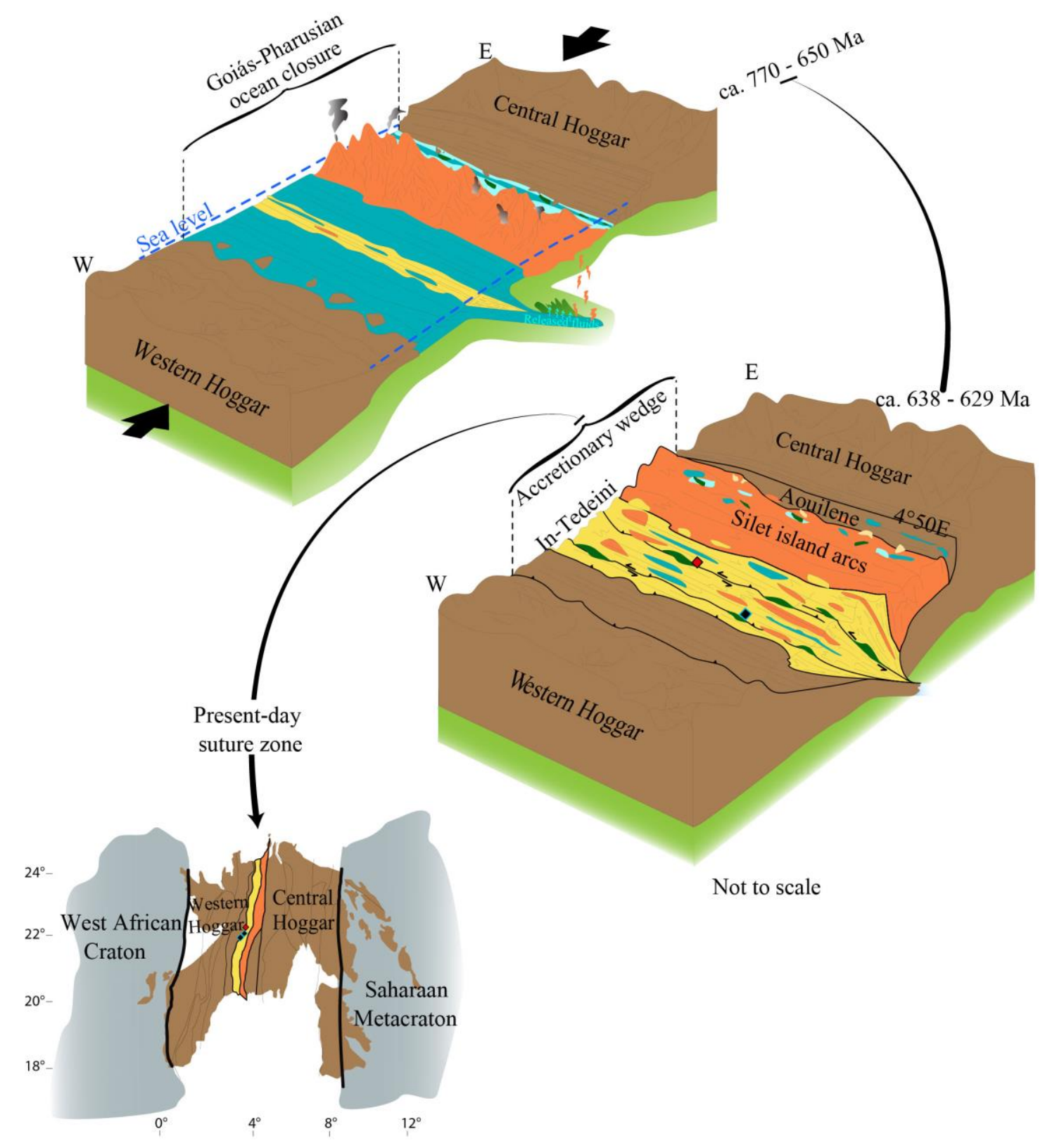




\section{Supplementary data:}

Supplementary data 1: KMZ file containing the Google map location of the most important areas and samples investigated in this article.

Supplementarydata 2: Representative electron microprobe analyses of serpentine phases in the studied serpentinites and talc in Talc-schist rocks.

Supplementarydata 3: Representative electron microprobe analyses of Spinel cores.

Supplementary data 4: Whole rock Major oxides and trace element compositions of the studied serpentinites and chloritites.

Supplementary data 5: Dating analyses.

Supplementary data 6: REE modelling parameters. 